\title{
BARGAINING IN THE SHADOW OF DEMOGRACY
}

\author{
DAVID DANA ${ }^{\dagger}$ AND SUSAN P. KONIAK ${ }^{\#}$
}

\section{INTRODUCTION}

The government needs money, for example, to save the Social Security system, improve our schools, and provide health care to those too poor to afford it. The problem is that Americans are unwilling to pay for the government they want. We hate taxes, always have, always will.

So, how might we fund the government without raising taxes? Debt has been the traditional answer. After years of federal budget deficits and an ever-escalating federal debt burden, however, Americans have become, at least for the moment, almost as attached to the idea of a balanced budget as they are to tax cuts. The question now becomes more difficult: how do we fund expensive but cherished old government programs and, if possible, some modest but not cost-free new programs while lowering taxes (or at least not raising them) and keeping the budget balanced? One answer: the government could find something valuable to sell.

The government has many assets: land, monuments, collectibles (original documents, such as the Declaration of Independence, the Constitution, and a wide range of one-of-a-kind objects from Archie Bunker's armchair to the Enola Gay), and other more esoteric forms of property, like the broadcast waves. The asset with the greatest value to the greatest number of potential buyers, however, is not among those listed. That asset is the power to make laws. Generally speak-

$\dagger$ Professor, Northwestern University School of Law. We also wish to thank the participants in the faculty workshops at Boston University, Cornell, Harvard, New York University, Northwestern, and the University of Texas law schools, whose questions helped us work through the ideas presented here. We are indebted to Mary Ann Peterson, Harvard Law School '99, for her research assistance, can-do spirit, sharp mind, and good humor. Finally, we thank Maura Kelley for sticking with us through the many iterations of this work and for not letting us down.

†† Professor, Boston University Law School. We thank George M. Cohen, John D. Geanakoplos, and Richard McAdams for the time each of them so generously gave us to discuss the questions we address in this paper and for the insight each of them brought to those questions. 
ing, our law prohibits government agents from selling for personal gain that part of the government's law-making power that they control, ${ }^{1}$ but our question here is different. Does and should our law allow the government to raise revenue to swell the public coffers by promising to pass and keep in place certain laws? To make this question more concrete, we ask you to consider the following example.

An industry, say the tobacco industry, wants a certain law passed. It details the legal protection for which it is willing to pay. For example, it drafts a law that includes some form of tort immunity for damages caused by its products and some restrictions on the FDA's ability to regulate nicotine. Its offer is this: if Congress enacts the law and promises to keep it in place for twenty-five years, the industry will pay into the national treasury some amount of money, say $\$ 368$ billion, $\$ 68$ billion due upon enactment and the rest due in annual installments to be paid over the next twenty-five years. ${ }^{2}$

Should Congress or any other legislature in this country make such a deal? If a legislature does, should a court enforce that deal? What about holding an auction to fund a tax cut? Entities and individuals could submit bids-bills they would like passed and the

${ }^{1}$ See 18 U.S.C. $\$ 201$ (1994) (criminalizing bribery of public officials). We say "generally speaking" at the beginning of the sentence in the text because if "personal gain" includes "getting elected," then our law provides some room for the exchange of law-making authority for personal gain. See Buckley v. Valeo, 424 U.S. 1, 3-5 (1976) (holding that provisions limiting individual contributions to campaigns were constitutional, despite First Amendment objections; that provisions limiting expenditures by candidates on their own behalf violated the candidates' rights to freedom of speech; that provisions limiting total expenditures in various campaigns were invalid; that provisions limiting the amount which any individual could spend, independent from but relative to the candidate, impermissibly abridged freedom of speech; that the reporting requirements under the Act were valid; and that the Federal Elections Commission created by the Act violated the Appointments Clause, insofar as it had primary responsibility for conducting civil litigation, rule-making authority, and the power to determine eligibility for funds and federal elective office); Pamela S. Karlan, Not by Money but by Virtue Won? Vote Trafficking and the Voting Rights System, 80 VA. L. REV. 1455, 1460 (1994) (discussing how our law allows politicians to promise during a campaign to support $x$ or $y$ legislation, in exchange for the votes of the citizenry needed to win office, while prohibiting those seeking election from offering money, as opposed to performance, in exchange for citizen votes).

2 The deal crafted in the spring of 1997 by some state attorneys general and the big tobacco companies (the so-called June 20 "settlement agreement") was at its core such an offer, albeit one made-up to look like something else. Our view of the deal brought us to the questions we raise in this Article, giving these questions an immediacy that they otherwise would not have had. It is, however, not critical to accept our characterization of what Mississippi Attorney General Mike Moore and his colleagues announced on June 20,1997. We aim here only to clarify what we mean when speaking of the government raising revenue by selling its law-making power. 
amount of money they are willing to pay to keep those laws in place for the next twenty-five years. While many legal academics have addressed topics that bear on these matters, we have been unable to locate any discussion in the literature of entities or individuals buying laws from the government. ${ }^{3}$ Perhaps this is because there has been no reason to take the issue seriously in the past. The 1997 offer by the tobacco industry changed that, and a consideration of the legitimacy of such deals is a matter that now seems long overdue.

Tobacco aside, there is another reason to take up these questions now: the rise of contracts that trade performance for favorable regulatory treatment or regulatory stability. Raising money is not the only concern of government-protecting the general welfare of the people and the nation is another. What about selling the power to make or change a law (or regulation) in exchange for a promise by private parties to do something in the public interest? Indeed, the proposed tobacco deals also included this kind of regulation-for-performance exchange: the tobacco companies would agree to certain restrictions on their claimed First Amendment right to advertise (and would pay money) in exchange for the legal protections they wanted written into law and maintained for twenty-five years.

In the paradigmatic regulation-for-performance contract, the regulated entity contractually promises the government that the entity will provide or do something that is not otherwise clearly required by extant law. In return, the government contractually promises the regulated entity to maintain the regulatory regime set out in the contract. If the government breaches its promise of regulatory stability, it must pay contract damages. Consider, for example, the Department of Interior's ("DOI") heavy reliance on habitat conservation agree-

${ }^{3}$ The literature does include economic analyses of the efficiency of providing compensation to private parties when the governor changes regulations. See Michael J. Graetz, Legal Transitions: The Case of Retroactivity in Income Tax Revision, 126 U. PA. L. REV. 47, 87 (1977) (arguing that the implementation of transitional relief prevents efficient government policies and that people should make investments with the expectation that political policies may change); Louis Kaplow, An Economic Analysis of Legal Transitions, 99 HARV. L. REV. 509, 615-16 (1986) (arguing that since governmental transitional relief is generally undesirable, relying on the market to address the effects of changes in government policy is more efficient); Kyle D. Logue, Tax Transitions, $O p$ portunistic Retroactivity, and the Benefits of Government Precommilment, 94 MICH. L. REV. 1129,1131 (1996) (arguing that "for certain types of tax transitions, the efficient transition policy entails full transition relief in the form of guaranteed grandfathering"). The idea that the government might sell its law-making authority to raise revenue, however, is absent from the literature. Because academics, unlike tobacco lawyers, failed to understand the significance of regulatory contracts, the analysis of regulatory contracts suffered and the underlying values at stake were obscured. 
ments as a means of implementing the Endangered Species Act. ${ }^{4}$ Under the DOI's program, private landowners and regulators agree to a plan for conservation and habitat protection of threatened or endangered species on private land. ${ }^{5}$ In return for their willingness to undertake contractual commitments to fulfill specified habitat conservation measures, private landowners receive a contractual promise from the DOI to either forego imposing additional conservation requirements in the future or to pay compensatory damages should the DOI or another branch of government do so. Should agencies make such deals? If Congress decides to impose additional conservation requirements, should courts order the government to pay damages to all parties with a DOI contract?

Regulatory contracts, especially the regulation-for-performance variety, are suddenly in vogue. The Supreme Court recently placed its imprimatur of approval on such contracts in United States v. Winstar Corp. ${ }^{6}$ Winstar involved a deal between federal bank regulators and certain solvent banks wherein the regulators allegedly promised to maintain certain regulatory standards governing the calculation of required capital reserves. In return, the solvent banks agreed to merge with insolvent banks that otherwise would have immediately fallen into federal receivership. ${ }^{7}$ Subsequently, Congress responded to the crisis in the savings and loan industry by passing the Financial Institution Reform, Recovery, and Enforcement Act ("FIRREA"), which included provisions on calculating required capital reserves that would have disallowed some of the accounting methods allegedly guaranteed by the regulatory contracts. ${ }^{8}$

In Winstar, the Supreme Court held that the more stringent capi-

16 U.S.C. $\$ \$ 1531-1544$ (1994).

5 DOI's habitat conservation program is outlined in the Habitat Conservation Plan Assurances ("No Surprises") Rule, 63 Fed. Reg. 8859 (1998). See also Donald C. Baur \& Karen L. Donovan, The No Surprises Policy: Contracts 101 Meets the Endangered Species Act, 27 ENVTL. L. 767 (1997) (arguing that the No Surprises program works to the benefit of both endangered species and landowners); Amy C. Derry, No Surprises Afler Winstar: Contractual Certainty and Habitat Conservation Planning Under the Endangered Species Act, 17 VA. ENVIL. L.J. 357 (1998) (noting the Supreme Court's willingness to balance government's role as a private contractor and sovereign power in favor of its contracting responsibilities); Eric Fisher, Habitat Conservation Planning Under the Endangered Species Act: No Surprises $\mathcal{E}^{2}$ the Quest for Centainty, 67 U. CoLO. L. REv. 371, 391-97 (1996) (discussing the problems that may arise in trying to enforce a contractual agreement between the government and private parties).

518 U.S. 839 (1996).

${ }^{7}$ See id. at 847.

${ }^{8} 12$ U.S.C. \& 1464(t) (1994) (stating that "the Bank Board... encourag[ed] healthy thrifts ... to take over ailing institutions in a series of 'supervisory mergers"). 
tal reserve requirements included in FIRREA breached the regulatory contract and that the government was therefore liable for damages.' In so holding, the majority indicated that courts should interpret and enforce almost all regulatory contracts under standard contract law rules. $^{10}$ As a general matter, regulatory contracts enjoy the same legal status as ordinary, nonregulatory contracts employed to constrain uncertainty in the private marketplace. The implicit premise of the Winstar plurality and concurring opinions is that regulatory contracts are no more normatively problematic-indeed, are as presumptively socially beneficial-as the ordinary, nonregulatory contracts that are the subject of standard contract law.

For its part, the Clinton Administration has been strongly attracted to regulatory contracts as a means of addressing contentious regulatory issues. While the President expressed some concerns about the details of the June 20 tobacco deal, his federal budget plan anticipated huge tobacco company payments but included no proposed tobacco tax from which such payments might come. ${ }^{11}$ It is reasonable to conclude that he was receptive, if not committed, to a deal that would call for the industry to make voluntary, i.e., contractual, payments in exchange for a law providing regulatory relief. ${ }^{12}$ As for trading the power to regulate for concessions above those required by law (in-

${ }^{9}$ See Winslar, 518 U.S. at 910 (holding that the United States is liable for breach of contract).

${ }^{10}$ See id. at $870-71$ (noting the propriety of applying ordinary contract principles to regulatory contracts).

${ }_{11}$ See One Budget: Many Interpreters, L.A. TIMES, Feb. 18, 1998, at B6 ("The new spending [in President Clinton's proposed budget] is to be offset . . . by a federal settlement with the tobacco industry that may or may not include a new tax on tobacco ...."); David Perlman, Science Spending War on the Horizon: Funds Clinton Stated Not Yet Available, S.F. CHRON., Feb. 13, 1998, at A2 (reporting that the President's budget proposed spending money that would come from tobacco companies but did not say whether the money would be realized through what Albert Teich, Director of Science and Policy, American Association of Advancement of Science, characterizes as "cigarette taxes, penalties on tobacco companies, voluntary payments or some combination of the three").

${ }^{12}$ See, e.g., Clinton Urges Damage Cap in Tobacco Bill: Move an Effort to Get Firms Back to Bargaining Table, DAIIAS MORNING NEWS, June 20, 1998, at IF (discussing Clinton's endorsement of liability limits for tobacco companies, which the President hoped will lure cigarette makers back to the bargaining table to resurrect tobacco legislation); Clinton Wants Tobacco Bill That Caps Damage Payments, DaIIAS MORNING NEwS, June 22, 1998, at 6D (same); Brian McGrory, Democrats Fuming over Clinton, Tobacco, BOSTON GLOBE, June 7, 1998, at A8 (noting that Democrats were angry over Clinton's alignment with Republican tobacco legislation); Philip Morris Chairman Sends Letter to Stockholders on Senate Tobacco Bill, BUS. WIRE, Apr. 20, 1998, available in LEXIS, Nexis library, BWIRE File (noting that the Clinton Administration closely monitored the June 20 settlement agreement). 
stead of for money), the DOI contracts discussed above are a centerpiece of the Clinton Administration's "reinvention" of environmental regulation. $^{13}$

Congress also seems open to the idea of raising money through selling law-making authority and has been generally supportive of regulatory contracts. The Senate responded to the tobacco industry's June 20 offer to pay $\$ 368$ billion over twenty-five years in exchange for Congress's promise to limit the industry's exposure to the legal process and adopt various procedural obstacles to the regulation of nicotine with a counter-offer, the McCain bill. ${ }^{14}$ Under the McCain bill, "participating" tobacco companies would promise to pay $\$ 514$ billion to the federal and state governments and to refrain from certain forms of advertising in exchange for the government's passage and maintenance of a law providing those companies and their agents some protection from lawsuits and from FDA regulation, albeit much less than the industry's offer had contemplated. ${ }^{15}$ More money for less law was an offer the industry could and did refuse.

The tobacco industry's gambit did not fail because Congress refused to trade its law-making authority for money. Rather, it failed, at

13 The Clinton Administration's Project XL Initiative in which companies contract for exemptions from some regulatory requirements in return for their commitment to go "beyond compliance" as to other regulatory requirements, represents another variety of regulatory contract. For discussions of Project XL, see Rena I. Steinzor, Reinventing Environmental Regulation: The Dangerous Joumey from Command to Self-Control, 22 HARV. ENVTL. L. REV. 103, 104 (1998) (analyzing experiments in reinventing the system that controls pollution through the encouragement of industry self-regulation as an alternative to traditional rules).

${ }^{14}$ National Tobacco Policy and Youth Smoking Reduction Act, S. 1415, 105th Cong. (1998).

${ }^{15}$ Both the McCain bill and the legislation embedded in the June 20 agreement gave tobacco companies a choice: contract with the government (agree to give $a$ and $b$ for $x$ and $y$ ) or the government will regulate the companies (companies give $a$, and independent of the government's receipt of $a$, the government gives $y$, which it may take away when it chooses). See infra note 76 (discussing provisions of both deals). The tobacco companies that drafted the June 20 deal devised this structure in order to coerce non-signing tobacco companies to either sign similar deals or face government fines and receive less favorable regulatory treatment-not much of a choice. The tobacco companies that devised this headlock nearly found themselves caught in its grip when the Senate Finance Committee changed the terms of the proposed contracts but kept the coercive take-it-or-suffer device. They escaped by running an expensive and successful lobbying drive to kill the McCain bill. The companies' lobbying to kill the legislation helped mask the fact that the McCain bill, like its predecessor, the June 20 "settlement agreement," contemplated a contractual relationship, however coerced, between the government and big tobacco. Given the Hobbesian choice built into these bills, it is easy to understand why the tobacco companies could not just walk away from the congressional contract negotiations that they had begun. 
least for the time being, ${ }^{16}$ because the parties could not agree on terms. Perhaps another industry (with a better public image than tobacco) will have better luck. ${ }^{17}$ Congress may have proved itself a difficult bargaining partner, but it has also demonstrated its willingness to negotiate. Before Congress goes any further down this path or other government entities decide they can bargain their law-making authority for money or other goods, we, as a nation, should consider the wisdom of such horse-trading. The tobacco deals spawned a lively national debate about public health, the dangers of nicotine, the FDA's power to regulate, the industry's right to advertise, the size of attorneys' fees, and the regressive nature of a tobacco consumption tax. ${ }^{18}$ That debate did not include, however, a discussion of whether the government should trade its law-making authority for money. It is now time for that discussion to begin. To all those inclined to minimize this problem by pointing out that as a practical matter lawmaking is always a market commodity, we answer that not everything that is, should be. The existence of black and grey markets does not necessarily mean it would be a good idea to create a white one. We believe it is not.

${ }^{16}$ In September of 1999, the Justice Department announced a major lawsuit against big tobacco. See Marc Lacey, Tobacco Industry Accused of Fraud in Lawsuit by U.S., N.Y. TIMES, Sept. 23, 1999, at Al (reporting on the Justice Department's civil lawsuit against cigarette companies). If that lawsuit settles, as most lawsuits do, we may see once again a settlement contract that calls for the passage of legislation in exchange for industry payments although we have little doubt that once again the legislation would be characterized as a "give" by tobacco and not a "give" to tobacco, which we believe it would actually turn out to be.

17 The move by governments to sue industries over the production of dangerous products continues. See generally Barry Meier \& Richard A. Oppen, Jr., States' Big Suits Against Industry Bring Battle on Contingency Fees, N.Y. Times, Oct. 15, 1999, at A1 (reporting on the debate over the enormous legal fees that accrue in lawsuits against large companies). In settling those lawsuits, industries and governments will have many opportunities to follow the legislation-for-money scenario developed by the tobacco industry in 1997. The buying of legislation through settlement contracts may yet turn out to be the wave of the future.

${ }^{18}$ While it is true that the effects of the McCain bill on smokers would have been substantially the same as the effects of a tax on tobacco, it is also true that the bill did not call for a tobacco tax. The bill called for "participating tobacco companies" to pay annual fees to the federal government and required those companies to make "good faith" efforts to see to it that the complete costs of those fees would be passed on to the consumer. S. $1415 \S \S 402,404$. This procedure demonstrates the essentially contractual nature of the legislation. 


\section{A TOPOLOGY OF REGULATORY CONTRACTS}

\section{A. Distinguishing Regulatory Contracts from Other Means of Controlling Present and Future Political Outcomes}

As a preliminary matter, we need to refine the concept of a "regulatory contract." Regulatory contracts, as we will use the term, are contracts between government entities and private actors subject to, or potentially subject to, regulation in which the government promises to maintain (or to enact and maintain) a specified regulatory regime in exchange for either money or performance by the private party. Before moving on, however, the term "government entities" deserves some more attention. ${ }^{19}$

By specifying that government entities, as opposed to government agents, enter regulatory contracts, we mean to distinguish these contracts from bribes-money or services promised to an individual government agent in exchange for the agent's promise to use her official position to maintain or enact a specified regulatory regime. Offering or accepting a bribe is a crime, as is offering or accepting something of value for the past performance of an official duty, known as an illegal gratuity. Regulatory contracts, as we have defined them, exclude bribes and illegal gratuities. ${ }^{20}$

Regulatory contracts may be conceived as a response to the commitment dilemma in politics. The essence of the commitment dilemma is that, although an interest group or constituency can invest

${ }^{19}$ The contracting government entity may be either an executive agency or the legislature. Where the contracting government entity is a regulatory agency, the agency may purport to bind only itself in its future exercise of regulatory authority of matters (then) within the agency's lawful discretion, or it may purport to bind itself and the rest of the government, including the legislature. In the limited version, the agency commits only that it will not exercise its discretion to alter the regulatory treatment of the industry. In the more expansive version, the agency is committing not only that it will not exercise its discretion to alter the regulatory treatment of the industry but also that the legislature will not mandate changes in the agency's regulatory treatment. The analysis we present in this paper is designed to cover both versions of agency regulatory contracts as well as regulatory contracts enacted as law by legislatures. We believe that the normative concerns raised by agency contracts, particularly the expansive type, are somewhat greater than those raised by legislative contracts, and we attend to the greater problems posed by agency contracts throughout this Article.

${ }^{20}$ Which is not to say that we see no relationship between the two phenomena. While it is possible that regulatory contracts would capture for the government some of the wealth now being diverted to private pockets for government favors, it is also possible that regulatory contracts will become so valuable to private parties that bribes and illegal gratuities increase to ensure that individual government agents support these contracts. 
or work hard to secure favorable legislation or regulation, the investment is rendered meaningless if the legislation or regulation can readily be revised or revoked the next day. Successful or dominant players in the political process will seek not just to dictate but to stabilize or freeze political outcomes. There are other means of stabilizing political outcomes, but regulatory contracts, while not foolproof, offer some distinct advantages over the alternatives. Regulatory contracts aside, players in the political process have a wide range of alternatives available to assist them in dictating political outcomes and ensuring that those outcomes stay in place. These alternatives run the gamut from criminal to constitutionally protected conduct including, at one end of the spectrum, bribes, illegal gratuities, and possibly blackmail and, at the other end of the spectrum, the First Amendment right to speak and convince others that one's position is correct, and therefore should be and remain the law. ${ }^{21}$

Given our current system of financing elections, withholding and reallocating campaign contributions are among the most commonly used means of securing and maintaining political outcomes. Although potentially effective in controlling political outcomes, these methods have serious problems associated with them. First, whatever the contributions are buying, whether it be access (normatively troubling to the public but legal) or some promise to perform (normatively troubling and criminal), the parties to the deal have an interest in keeping the details of the exchange vague in order to avoid public condemnation or criminal sanction as well as to preserve the benefits of the deal. Vague promises, however, are simply not as valuable as concrete and specific ones.

Second, whether vague or specific, these promises for access (legal) or votes (illegal) are not enforceable, leaving room for opportun-

${ }^{21}$ See Buckley v. Valeo, 424 U.S. 1, 16 (1976):

Some forms of communication made possible by the giving and spending of money involve speech alone, some involve conduct primarily, and some involve a combination of the two. Yet this Court has never suggested that the dependence of a communication on the expenditure of money operates itself to introduce a non speech element or to reduce the exacting scrutiny required by the First Amendment.

Id; see also Burt Neuborne, The Supreme Court and Free Speech: Love and a Question, 42 ST. LoUIS U. L.J. 789, 795-97 (1998) (disagreeing with the Buckley Court's aggressive use of the First Amendment to frustrate Congressional efforts to deal with the distorting role of wealth in the democratic process); Bradley A. Smith, Money Talks: Speech, Comuption, Equality, and Campaign Finance, 86 GEO. L.J. 45, 47 (1997) (arguing that "the government interest in guarding against corruption is insufficient to justify the burdens that most campaign finance regulations place on free speech"). 
ism by politicians: get paid now, vote how one wants later. Opportunism of that sort is, of course, largely controlled by the fact that politicians generally will run again and thus are repeat players (as are the contributing parties) with an interest in maintaining a reputation for keeping their word. The fact that government decisions are almost always the product of collective action, however, makes it more difficult to control opportunism than the "repeat player" story might lead one to believe. Monitoring a "bought" politician, devoted to winning over the necessary votes to pass a measure, is no simple matter, particularly when collegial ties between elected officials and party loyalties may encourage public officeholders to cooperate in withholding accurate information on behind-the-scenes maneuvering of political matters.

Third, buyers have a collective action problem. To the extent that there is competition among similarly well-off groups for political support, each has an interest in paying a "bought" politician to renege on a previous promise (implicit or explicit) that was made to a competitor. None of this is to say campaign contributions are not worth the candle; it is to say that they are not always reliable as a means of either securing or maintaining a particular political outcome.

As to "speaking out," this method might prove quite effective at influencing outcomes, although there is always the chance that expensive ads will backfire. The bigger problem, however, is that "speaking out" is a terrible method of achieving stability. Talk generates talk, which is in itself destabilizing. Thus, while "speaking out" might prop up a stable regime that is under siege, it seems a singularly poor strategy for ensuring stability in the first instance.

To enhance the value of buying (access or promises to perform) from individual government actors (and thus increase the price each actor can command), buyers and government actors might jointly support institutional rules that increase the control that individual government actors wield over content and that also impede legislative or regulatory change. ${ }^{22}$ For example, as public choice scholars have

${ }^{22}$ See Jonathan R. Macey, Public Choice and the Legal Academy, 86 GEO. L.J. 1075, $1087-88$ (1998) (reviewing JERRY L. MASHAW, GREED, GHAOS, AND GOVERNANCE: USING PUBLic CHOICE TO IMPROVE PUBLIC LAW (1997)) (arguing that much of the "industrial organization" of Congress, as well as the reliance on administrative agencies, is designed to ensure the durability of political deals by making the passage of new legislation or the implementation of real regulatory reform difficult); Matthew $\mathbf{D}$. McCubbins et al., Structure and Process, Politics and Policy: Administrative Arrangements and the Political Control of Agencies, 75 U. VA. L. REv. 431, 481 (1989) (discussing how constraints placed on agencies provide politicians with warning of agency deviations 
noted, the committee system in Congress for the passage of legislation provides committee chairmen with enormous power to block even popular legislative proposals. Because changes in the identity of chairmen are relatively rare, normally occurring only when an election brings a new political party to power, the committee system tends to stabilize political outcomes. Moreover, even in the absence of any special means to stabilize political outcomes, natural institutional inertia can also be counted on to achieve some degree of stability.

Finally, in our political system, constitutional amendments can dictate and stabilize political outcomes. The Constitution removes certain issues from ordinary politics, but current constitutional provisions and jurisprudence provide industries with little protection against regulatory change, at least in the absence of a pre-existing regulatory contract. ${ }^{23}$ Additionally, industries would face a virtually impossible task were they to seek passage of protective constitutional amendments.

Regulatory contracts stabilize political outcomes by attaching a significant cost to regulatory change. ${ }^{24}$ The mere fact that political

and how structure and process impose delay, affording ample time for politicians to intervene before an agency can present them with a fait accompli).

${ }^{23}$ Recent interpretations of the Contract Clause provide private entities that have been able to secure regulatory contracts from state or local governments with constitutional protection from uncompensated changes in regulatory policy, marking a departure from the Supreme Court's post-New Deal approach to economic regulation. See discussion infra Part I.B.

${ }^{24}$ Some commentators have argued that a governmental guarantee of compensation for regulatory change actually will facilitate, rather than impede, regulatory change. See Glynn S. Lunney, Jr., A Critical Reexamination of the Takings Jurisprudence, 90 MICH. L. REv. 1892, 1955 (1992) (arguing that providing compensation to those affected by proposed legislation makes the enactment of such legislation more likely). The premise of this argument is that, without compensation, private actors that are likely to be disadvantaged by regulatory change will fight reform proposals. By contrast, if such groups are assured compensation, they will be indifferent to reform. Hence, more regulatory change will occur under a compensation regime than under a no-compensation regime.

We are unpersuaded by this argument. We believe that with a guarantee of compensation there will be situations in which an interest group that benefits from a regulatory contract will lack the political might to defeat reform proposals, but in which the legislature will be unwilling to incur substantial liability in exchange for regulatory reform. As we explain below, the cost of compensating the private beneficiaries of regulatory contracts will tend to be large because such beneficiaries have no incentive whatsoever to operate their businesses and make their investments in a way that would minimize the cost to them of regulatory change. See infra Part V.A. In fact, the estimated costs of compensating the thrifts for the costs of regulatory change run in the billions of dollars. See Michael Grunwald, Lawsuit Surge May Cost U.S. Billions; 125 Claims Allege Breach of Contract, WASH. POST, Aug. 10, 1998, at AI (reviewing thrift and other cases brought against the United States in the wake of Winstar and quoting Dep- 
players consummate regulatory contracts suggests that the contracts offer certain advantages over the alternative means of stabilizing political outcomes. One obvious advantage is that the government's promise to perform can be made explicit and specific without running afoul of extant criminal law or risking the public opprobrium that attaches to explicit promises of "access., ${ }^{25}$ The explicit and specific nature of the government promises that can be obtained in regulatory contracts is valuable wholly apart from whether the contracts are enforceable in court. When the government's promise is specific and a matter of record, the non-monetary costs to the government of breaking its word are increased. The more obvious it is that a promise was made and broken (functions of the explicitness and specificity of the bargain), the greater the reputational effects of reneging on the deal. ${ }^{26}$

uty Assistant Attorney General Stuart Schiffer as stating "[t]his is the largest family of cases we've ever had, and I've never seen dollars like this at stake. ... The money is so huge, you get kind of numb. ... Whenever I read about the budget surplus, I just think: Here it is"); Michael Grunwald, Thrift Wins $\$ 908$ Million from U.S. in Disprute from SE'L Crisis, WASH. POST, Apr. 10, 1999, at A6 ("A judge ruled today that the federal government must pay a California thrift more than $\$ 908$ million for reneging on $\mathrm{fi}$ nancial promises during the savings-and-loan crisis, a ruling that could herald the beginning of a second taxpayer-funded bonanza for the industry."). In times (such as our own) where new taxes are regarded as political anathema, in order to compensate for regulatory change, legislators would need to seize the money from some established program (benefiting some established interest group or constituency), and doing so would invariably come at great political cost. We believe that legislators generally will wish to avoid such politically fraught situations by ignoring or downplaying the need for regulatory reform for as long as possible.

Grandfather clauses, in contrast to compensation payments, may well facilitate the passage of reform legislation. When the legislature grandfathers current beneficiaries of a certain regulatory regime from new regulations, it reduces or eliminates the opposition of those beneficiaries without extracting money from some other interest group and entailing associated political costs. The prevalence of grandfather clauses in legislation establishing new regulatory regimes attests to their political appeal. See Kaplow, supra note 3, at 584 ("Grandfather provisions ... are commonly used to mitigate the immediate impact of policy changes."). The principal problem with grandfather clauses, however, is that in many contexts they may dramatically limit the reach of regulatory reform and its potential societal benefits. For other critiques of grandfather clauses on efficiency and distributive justice grounds, see Peter Huber, The Old-New Division in Risk Regulation, 69 VA. L. REV. 1025, 1075 (1983) (arguing that grandfathering itself creates perverse incentives that increase aggregate threats to public health).

${ }^{25}$ That is not to say that regulatory contracts might not themselves engender public condemnation. However, at least up to this point, regulatory contracts have received little direct public attention. For that reason, as well as others, such as the normative legitimacy conveyed by the concept of "contract" itself, these contracts have largely escaped the normative taint that might otherwise attach to them. We return to the "transparency" questions raised by regulatory contracts later. See infra Part II.A (discussing the virtues of transparency).

${ }^{26}$ Of course, the reputational effects of reneging on a bribe (by definition a sur- 
Another advantage is that, to the extent that courts treat these contracts as valid, legislatures or agencies cannot unilaterally annul them. None of the other alternatives for dictating or maintaining political change can similarly be fine-tuned, be open to public view, and be enforced in court. For these reasons, regulatory contracts are superior to other means of stabilizing political change.

Regulatory contracts, however, are not foolproof. For one thing, sometimes political officials will choose political change even though it means the government would be seen as breaking a promise and a court might award sizeable contract damages. As for the private contracting party, it might not see damages as the equivalent of the contracted-for performance. There are many reasons why that might be true. First, the process of seeking and collecting damages is expensive, even in the absence of protracted litigation. Second, some of the damages occasioned by regulatory change may be impossible to quantify or prove, although the private party may well perceive those damages to be real. Third, the private party may fear a domino effect: one change in a regulatory regime might beget other changes.

Even if there were reasons to assume that private parties would see the right to receive damages as the equivalent of the promised performance, the "right" to such damages upon breach of a regulatory contract is highly uncertain. Contract damages are only available to the extent that the courts treat these contracts as valid, and, to put it mildly, the courts have not been consistent in this regard over time. Even when private actors enter into a regulatory contract with the full expectation that current judicial doctrine would support its enforceability, they assume the risk that the doctrine (and the underlying attitudes and composition of the courts) will have changed by the time they need to enforce the contract. Moreover, because of the unique power that governments wield, a private actor might find that in certain circumstances it is unwise even to threaten the enforcement of a regulatory contract because the government might retaliate against the actor in any number of ways.

\section{B. The Supreme Court and Regulatory Contracts}

Over the many years in which the Supreme Court has struggled with the enforcement of what we call regulatory contracts and the questions about the inalienability of sovereignty that such contracts raise, two approaches to protecting the sovereignty of government

reptitiously made promise) are not just quantitatively different, they are qualitatively different as well. 
have emerged: one procedural, the other substantive. The first is more or less coherent; ${ }^{27}$ the other is not. In recent years, both methods have been all but abandoned. Here, we provide a brief overview of the Supreme Court's various approaches to this subject.

Early in its history, the Supreme Court under Chief Justice Marshall enforced regulatory contracts with a vengeance. ${ }^{28}$ The Court seemed unconcerned about the particular aspect of sovereignty that the contract ceded ${ }^{29}$ or the corruptness of the circumstances that surrounded the contract's formation. ${ }^{30}$ For the most part, the inviolabil-

${ }^{27}$ But see, e.g., James L. Kainen, Nineteenth Century Interpretations of the Federal Contract Clause: The Transformation from Vested to Substantive Rights Against the State, 31 BUFF. L. REv. 381, 437-45 (1982) (describing the Court's Contract Clause jurisprudence as fundamentally incoherent without distinguishing the procedural route's inherent, if somewhat unrealized, coherence from the substantive route's ipsi dixit nature).

${ }^{28}$ See Stewart E. Sterk, The Continuity of Legislatures: Of Contracts and the Contracts Clause, 88 CoLUM. L. REv. 647, 670-72 (1988) (describing the Marshall Court's response to legislative attempts to avoid contractual commitments and labeling this the Supremacy of Contract era).

Marshall wrote three opinions for the Court in response to legislative attempts to escape obligations undertaken by predecessors. In all three, the Court invalidated the subsequent legislative action and upheld the contract rights of the legislature's contract partner. See Trustees of Dartmouth College v. Woodward, 17 U.S. (4 Wheat) 518 (1819) (finding unconstitutional a state act altering Dartmouth College's charter by declaring it a public corporation); New Jersey v. Wilson, 11 U.S. (7 Cranch) 164 (1812) (holding unconstitutional an act of the New Jersey legislature which would have stripped tax-exempt status from a plot of land); Fletcher v. Peck, 10 U.S. (6 Cranch) 87 (1810) (declaring that a legislature cannot void its past contracts, including grants of land, by passing new legislation).

${ }_{29}$ In Fletcher, Marshall intimated that the legislature might be disabled from undoing the contracts of its predecessors even without an express constitutional restriction. First, he asserted that legislation presuming to annul contract rights against the government "if legitimate, is rendered so by a power applicable to the case of every individual in the community." Fletcher, 10 U.S. (6 Cranch) at 135 . Then, several paragraphs later, he concluded that " $[t]$ he validity of this rescinding act, then, might well be doubted, were Georgia a single sovereign power." Id. at 136. By the time the Court decided Trustees of Dartmouth College $v$. Woodward, Marshall had concluded that only the Constitution, and not independently derived natural law principles, prohibited the legislature from altering the college's charter. See Sterk, supra note 28, at n.68.

${ }_{30}$ In Fletcher, the Court stated:

It would be indecent, in the extreme, upon a private contract, between two individuals, to enter into an inquiry respecting the corruption of the sovereign power of a state. If the title be plainly deduced from a legislative act, which the legislature might constitutionally pass, if the act be clothed with all the requisite forms of a law, a court, sitting as a court of law, cannot sustain a suit brought by one individual against another founded on the allegation that the act is a nullity, in consequence of the impure motives which influenced certain members of the legislature which passed the law.

Fletcher, 10 U.S. (6 Cranch) at 131. 
ity of legislatively made contracts remained intact until after the Civil War. During the Taney era, however, signs of Supreme Court dissatisfaction with the supremacy of the contract model began to surface. ${ }^{31}$ What is most interesting about the first two cases before the Taney Court to break with Chief Justice Marshall's approach is that the first case marks the start of the procedural approach to protecting sovereignty and the second case marks the start of the substantive approach.

The first case was Proprietors of the Charles River Bridge v. Proprietors of the Warren Bridge, decided in 1837. ${ }^{32}$ Massachusetts had granted a charter to a private company to construct a bridge (the Charles River Bridge) over the Charles River and to collect tolls for forty years. Before the forty years came to an end, the legislature granted another company a charter to build a bridge over the Charles River (the Warren Bridge), provided that as soon as construction expenses were recovered, and in any event in no later than six years, travel over the bridge would be free. ${ }^{33}$ The Charles River Bridge proprietors argued that the Warren Bridge legislation violated their contract. ${ }^{34}$ Chief Justice Taney rejected this claim, holding that their contract did not explicitly grant them an exclusive right. ${ }^{35}$ This holding's significance must be assessed in light of Justice Story's review of the record in his dissent, which shows that there was evidence that the intention of the parties was to grant just such an exclusive right. ${ }^{36}$ Chief Justice Taney

'The dissent in Fletcher stated:

As to the idea, that the grants of a legislature may be void because the legislature are corrupt, it appears to me to be subject to insuperable difficulties. The acts of the supreme power of a country must be considered pure for the same reason that all sovereign acts must be considered just; because there is no power that can declare them otherwise. The absurdity in this case would have been strikingly perceived, could the party who passed the act of cession have got again into power, and declared themselves pure, and the intermediate legislature corrupt.

Id. at 144 .

${ }_{32} 36$ U.S. (11 Pet) 420 (1837).

33 See id. at 537 (finding that the charter provided that the Warren Bridge "was to be surrendered to the state" as soon as the expenses of building and supporting it were reimbursed but that the period was not to exceed six years from the time the company commenced receiving tolls).

${ }^{34}$ See id. (stating that the plaintiffs charged "that the act for the erection of the Warren Bridge impaired the obligation of the contract between the commonwealth and the proprietors of the Charles River Bridge").

${ }^{35}$ See id. at 548-49 ("This is the whole grant. There is no exclusive privilege given to [the plaintiffs] over the waters of the Charles river ....").

${ }^{36}$ See id. at 614-17 (Story, J., dissenting) (asserting that "the grant carried with it an exclusive franchise to a reasonable distance on the river"). 
wrote: "[I]n charters of this description, no rights are taken from the public, or given to the corporation, beyond those which the words of the charter, by their natural and proper construction, purport to convey. ${ }^{37}$ Thus, what came to be known as the "unmistakability" doctrine was born-a doctrine that stood more or less unchallenged for 150 years until it was gutted by the Supreme Court in Winstar.

The second of these cases, West River Bridge Co. v. Dix, decided in 1848 , held that the government could not contract away its eminent domain power. ${ }^{39}$ Vermont had given the West River Bridge Company an exclusive franchise to collect tolls for crossing the West River. ${ }^{40}$ As the demand for bridges increased, Vermont passed legislation providing for the revocation of such franchise rights to permit the building of public bridges. ${ }^{41}$

[I]nto all contracts, whether made between States and individuals or between individuals only, there enter conditions, which arise not out of the literal terms of the contract itself.... [T] hey are always presumed, and must be presumed, to be known and recognized by all .... Such a condition is the right of eminent domain.

This approach, which treats the inalienable aspects of sovereignty as self-evident, echoes through all the later decisions in this line of cases-collectively referred to as the "reserved powers" cases. ${ }^{43}$ Despite the seemingly arbitrary nature of designating some powers of government as too essential to be traded away without any serious attempt to explain why these powers deserved such special treatment, the substantive approach to protecting sovereignty took off in earnest after the Civil War.

Fueled undoubtedly by the Court's mistrust of Reconstruction governments, what we will call the Sovereignty Century-the period from the late 1870 s to the late 1970 s-took off with a bang with three

${ }^{37}$ Id. at 549.

${ }^{38}$ See United States v. Winstar Corp., 518 U.S. 839, 872-87 (1996) (plurality opinion) (discussing the origins of the unmistakability doctrine and why it should not be expanded).

${ }_{39} 47$ U.S. (6 How.) 507, 535-36 (1848) (considering a challenge against the state's attempt to revoke West River Bridge Company's exclusive right to construct a bridge over the West River).

${ }^{40}$ See id. at 530 (describing West River Bridge Company's arrangement with Vermont).

${ }^{41}$ See id. at 513-14 (discussing the legislative history of the exclusive franchise given to West River Bridge Company and its subsequent withdrawal).

Id. at 532.

${ }^{43}$ See Winstar, 518 U.S. at $874-75$ (reviewing the "reserved powers" doctrine and the cases that gave rise to it). 
decisions issued in a three-year period. In each of these cases, the Court refused to enforce regulatory contracts on the ground that the contracts purported to bargain away that which could not be bargained away-core aspects of sovereignty. ${ }^{44}$ While some regulatory contracts managed to escape both the procedural and substantive nets cast wide by the Supreme Court during the Sovereignty Century, the chance that damages would be awarded against the government for breaching a regulatory contract became slimmer and slimmer as the Century wore on.

By the 1940s it seemed that no regulatory contract was safe from the sweep of the reserved powers doctrine, ${ }^{45}$ the substantive side of

${ }^{41}$ Skepticism about the legitimacy and integrity of Reconstruction governments undoubtedly made it easier for the Court to countenance legislation passed by postReconstruction state governments abrogating Reconstruction contracts. That is not to say, however, that suspicion of Reconstruction governments by itself explains the dawn of what we are calling the Sovereignty Century. In a fascinating article entitled The Classical Corporation in American Legal Thought, Herbert Hovenkamp explains that the demise of Chief Justice Marshall's treatment of government contracts as nearly inviolate and the near simultaneous emergence of substantive due process, particularly the ascension of the "right" to contract, were twin developments both linked to a shift in economic theory from mercantilism to laissez-faire economics. Herbert Hovenkamp, The Classical Comporation in American Legal Thought, 76 GEO. L.J. 1593, $1601-04$ (1988) (discussing the development and decline of classical corporate theory in America). In a mercantilist regime, governmental grants of vested rights are seen as essential to economic development; under laissez-faire market theory, the state ideally grants little or nothing but is dedicated to protecting the right to bargain and the pursuit of economic self-interest. The shift from mercantilism to laissez-faire economics explains what might otherwise appear contradictory: the demise of the Contract Clause and the emergence of the right to contract as a fundamental constitutional right. Hovenkamp's article ends with a description of the "post-classical" corporation, a highly regulated entity that little resembles either its mercantilist ancestor, the "pre-classical corporation," or its "classical" parent, of which, Hovenkamp claims, little remained after the New Deal. Id. at 1688-89. Hovenkamp was writing, however, pre-Winstar. After Winstar, the post-classical corporation resembles its mercantilist ancestor a good deal more than it did when Hovenkamp examined it.

${ }^{45}$ See, e.g., Faitoute Iron \& Steel Co. v. City of Asbury Park, 316 U.S. 502 (1942) (including for the first time the power to modify debt obligations in the pantheon of powers essential to sovereignty). Prior to this case, powers connected to the state's financial obligations had been largely exempted from the essential list, which is not to say that the explanation of which powers were not essential to sovereignty was any more illuminating than the explanation of which powers were. For example, in Stone v. Mississippi, Chief Justice Waite stated:

While taxation is in general necessary for the support of government, it is not part of the government itself. Government was not organized for the purposes of taxation, but taxation may be necessary for the purposes of government. As such, taxation becomes an incident to the exercise of the legitimate functions of government, but nothing more.

101 U.S. 814, 820 (1879). 
sovereignty protection. While the procedural side remained as extant doctrine, there was little need to rely on it because of the triumph of substantive protection. In the last part of the Sovereignty Century, from the early 1940s to the late 1970s, when protection for sovereignty had reached its zenith, there was virtually no chance that a court would enforce a regulatory contract in the face of a later legislative act that would effectively cancel the promise.

In 1977, with the decision in United States Trust Co. v. New Jersey, the Sovereignty Century ended. ${ }^{46}$ The Supreme Court held that New Jersey $^{47}$ was liable to the bondholders because it enacted legislation which violated the State's promise not to use revenues pledged as security for bonds in order to finance new railroad projects. ${ }^{48}$ Justice Blackmun, writing for the Court, expressed doubt about the coherence of the substantive side of sovereignty protection, calling the effort to sort the government's powers into the saleable and the inalienable "formalistic." He suggested that the exercise therefore should not be determinative of judicial decisions regarding enforceability. ${ }^{50}$ Nonetheless, he stated that the cases from the Sovereignty Century that relied on such distinctions "contain an important element of truth." ${ }^{51}$ For Justice Blackmun, that truth was that the State's "finan-

${ }^{46} 431$ U.S. 1 (1977).

${ }^{47}$ In effect, the Court held the same true for New York as well since it had made and broken the same promise. One might read United States Trust as limited to actions brought pursuant to the Contract Clause and hence inapplicable to cases involving the federal government. In Winstar, however, a majority of the Justices treated the Contract Clause cases as precedent relevant to the federal government's obligation to honor its promises. See Winstar, 518 U.S. at 873-74 (relying on a number of the Court's previous decisions which apply the Contract Clause to public contracts). The Court seemed no more willing to protect the federal government's sovereignty through the maintenance of substantive barriers than it had been willing to protect state sovereignty in this manner in recent years. See id. at 889 (maintaining that the reserved powers inherent to sovereignty could not be bargained away regardless of the procedural protections in place and were inapplicable because "a contract to adjust the risk of subsequent legislative change does not strip the Government of its legislative sovereignty"); id. at 922-23 (Scalia, J., concurring) ("The notion of 'reserved powers' . . . stand[s] . . . for the proposition that certain core governmental powers cannot be surrendered; thus understood, that doctrine would have no force where . . . the private party to the contract does not seek to stay the exercise of sovereign authority, but merely requests damages for breach ...." (citation omitted)).

${ }^{18}$ See United States Trust, 431 U.S. at 10 (finding a New Jersey law repealing a prior agreement not to spend security of bonds a violation of the Contract Clause).

${ }^{49} I d$. at 23-24.

${ }^{50}$ See id. at 24 ("Such formalistic distinctions perhaps cannot be dispositive...."). ${ }^{51}$ Id. 
cial obligations" were surely on the binding side of the dividing line. ${ }^{52}$ Blackmun reasoned that governmental opportunism was most likely to be present when the State was reneging on a financial obligation. "If a State could reduce its financial obligations whenever it wanted to spend the money for what it regarded as an important public purpose, the Contract Clause would provide no protection at all. ${ }^{53}$ Whatever the merits of this line of reasoning, the fact is that it has not withstood the test of time. ${ }^{54}$ Instead, as Winstar showed, a majority of the current Court believes that, as long as the remedy sought for breach of a regulatory contract is damages, as opposed to specific performance, the obligation is financial and thus the contract is enforceable against the State irrespective of its underlying subject matter. ${ }^{55}$ In short, the substantive side of sovereignty protection is all but dead.

As to the procedural side, the unmistakability doctrine born in Charles River Bridge has been gutted. As Winstar showed, the Court stands ready to read into contracts implied promises by the government to assume the risk that the law will change in a manner inconsistent with the government's contractual promise. ${ }^{56}$ Thus a majority of

${ }^{52}$ Id. at $25-26$.

5s Id. at 26.

54 Justice Blackmun argued that the case for court enforcement of government contracts was strongest when "financial obligations" were at issue because the potential for governmental opportunism was greatest as to those contracts. Id. at 26 . We too distinguish regulatory contracts from what Justice Blackmun might call "financial obligations" (e.g., procurement contracts and debt obligations), arguing that the former should not be enforceable in court, although the reasons we give differ from his. The line we propose would leave the contract at issue in United States Trust on the regulatory, nonenforceable side of the line because it involves more than a promise to repay a debt at a specified interest rate. See discussion infra Part V.C. Despite our differences with the holding in Uniled States Trust and Blackmun's opportunism argument, we agree that an "important element of truth" underlies the distinction between regulatory contracts and what might be termed purely financial obligations. United States Trust, 431 U.S. at 24.

${ }^{55}$ As the plurality put it in Winstar: “The answer to the Government's contention that the State cannot barter away certain elements of its sovereign power is that a contract to adjust the risk of subsequent legislative change does not strip the Government of its legislative sovereignty." United States v. Winstar Corp., 518 U.S. 839, 888 (1996) (plurality opinion). Three Justices concurring in a separate opinion stated that the "reserved powers' ... doctrine would have no force where, as here, the private party to the contract does not seek to stay the exercise of sovereign authority, but merely requests damages for breach of contract." Id. at 923 (Scalia, J., concurring).

${ }^{56}$ Justice Souter's plurality opinion, in which Justices Stevens, O'Connor, and Breyer joined, maintains that the government's promise need not be "unmistakable" for a court to award damages for breach except in a somewhat ill-defined group of cases where the award of damages would be tantamount to an order of specific performance. See id. at 879-83 (plurality opinion) (finding the United States liable for 
breach of contract where the government had promised thrifts that supervision, goodwill, and capital credits would be counted toward satisfaction of the regulatory capital requirements). The plurality's assertion that its position, namely that the unmistakability rule is limited to those instances in which specific performance against the government is requested, is consistent with long-established precedent, is wrong. Before Winstar, the Court had never indicated that the applicability of the unmistakability doctrine turned on the nature of the relief sought. Moreover, as Justice Rehnquist explained in his dissent (which Justice Ginsburg joined in part), damages claims were at issue in several of the pre-Winstar cases in which the Court had applied the unmistakability doctrine to deny the requested relief and thus relieve the government of its "promise" not to change the law. See id. at 926-28 (Rehnquist, C.J., dissenting) (discussing the damages claims at issue in United States v. Cherokee Nation, 480 U.S. 700 (1987), and Bowen v. Public Agencies Opposed to Social Security Entrapment, 477 U.S. 41 (1986)).

Justice Breyer joined the plurality opinion and wrote a concurring opinion to expand upon his views on unmistakability. Breyer begins by emphasizing that, as he reads the Court's precedent, the unmistakability doctrine, whatever its contours, was not meant to apply to "ordinary" government contracts. See id. at 916-17 (Breyer, J., concurring) ("It is difficult to believe that the Court intended ... to disable future courts from inferring ... a more narrow promise in more typical cases."). He sets forth two reasons to support his views that the unmistakability doctrine does not govern in the case before the Court. First, he expresses doubt that the absence of an "unmistakable" promise was the controlling factor in the earlier cases that purported to rest on the unmistakability doctrine. See id. at 913-14 (asserting that an "unmistakable" promise is not necessary in order for a private party to collect damages from the government). He argues that other factors, not the lack of an explicit government promise of stability in law, justified the results in those cases-factors that indicate how unlikely it was that the parties understood the government to be making such a promise. See id. at 910-12 (clarifying his view that government contracts are foremost governed by traditional contract law and by the intent of the parties). Second, he argues that the cases that purport to rest on the lack of an unmistakable promise all involve allegations that the government had made either a "broad promise not to legislate, or otherwise to exercise its sovereign power." Id. at 916. For Breyer, the Winstar facts fell into neither category. The surrounding facts suggested that the government agents intended to promise regulatory stability, not to deny it; and the promise of regulatory stability was narrow, not broad. Breyer thus seems to leave some room for the "unmistakability doctrine" to function when broad promises of regulatory stability are involved, although at the same time he asserts, in apparent agreement with the plurality opinion he joined, that the doctrine was never meant to supplant ordinary principles of contract construction. In sum, Breyer hedges a bit and in so doing only succeeds in making his approach to "unmistakability" difficult to discern.

Justice Scalia's concurring opinion, in which Justices Kennedy and Thomas joined, differs from the Souter plurality in that it accepts that the unmistakability doctrine applies to contracts with the government even when the only relief requested is damages. See id. at 919 (Scalia, J., concurring) (accepting the argument that the unmistakability cases had never been limited to non-damages claims and additionally arguing that "[v]irtually every contract" is in practice a promise to pay damages for nonperformance and nothing more). Justice Scalia, however, interprets the unmistakability requirement in such a way as to render it a nullity in practice. According to Scalia, "unmistakable" does not mean plain, precise, or explicit; it means simply a promise that a court could construe to be present from the contract's other terms or overall structure. See id. at 919-22 (discussing permissible inferences from the governmental promise not to change regulation). If, however, the unmistakability doctrine does not mean that a 
the Justices in Winstar were able to find a contractual commitment on the part of the government not to require more sensible loss reserves even though none of the many written or even alleged oral communications between the banks and regulators contained such an express promise.

The second procedural mechanism for protecting sovereignty, the express delegation doctrine, has similarly been nullified. ${ }^{57}$ In Home Telephone $\mathcal{E}^{2}$ Telegraph Co. v. Los Angeles, the Supreme Court read the unmistakability doctrine to require not only that the contract explicitly state that the government intended to cede an aspect of sovereignty but that the authority of the contracting arm of government to bargain away sovereignty be unmistakably present as well. ${ }^{58}$ Read

contract must contain a plain statement of the promise, it is hard to see how, if at all, the doctrine adds anything to ordinary principles of contract construction.

Indeed, Justice Scalia seems to interpret the banks' arrangements with the federal regulators using the general interpretive principles one might apply in discerning the intent behind routine business dealings between private entities. See id. at 920-21 (agreeing with respondents that the government's actions challenge the "reverse presumption" that a government will not agree to restrain its sovereign powers). Moreover, for those who doubt that Scalia's approach guts the unmistakability doctrine, it is important to notice that even under ordinary principles of contract construction, the conclusion Scalia reaches-that the government promised regulatory stability-is open to question. But even such principles would not mandate the conclusion Scalia reaches. According to Scalia, the circumstances of the transactions-namely, that the banks agreed to do something the government apparently wanted, i.e., merge with failing thrifts-established that the government was implicitly committing to maintain its favorable treatment of the banks' loss reserves practices for the "long term." Id. at 92122. Scalia emphasizes that, if the government instead were simply promising to maintain that favorable policy for the time being, the banks would have been receiving nothing of value and thus, as rational actors, would not have agreed to the merger transactions. Id. at 922 (explaining why he believes the promise was unmistakable). An agency promise, however, to implement and maintain for the time being a favorable policy is not necessarily (or even ordinarily) valueless to a regulated entity. Once a favorable policy has been established, it may well be much more likely to endure than if the policy had never been established in the first place.

57 According to the Souter plurality, the express delegation requirement "simply has no application to the present case, because there were no contracts to surrender the Government's sovereign power to regulate." Id. at 889-90 (plurality opinion). Thus, once again the plurality relies on the "agreeing to pay damages has nothing to do with sovereignty" argument to avoid one of the doctrines developed by earlier Courts to protect sovereignty.

${ }^{53}$ Home Tel. \& Tel. Co. v. Los Angeles, 211 U.S. 265, 273 (1908). The Court stated:

The surrender, by contract, of a power of government, though in certain welldefined cases it may be made by legislative authority, is a very grave act, and the surrender itself, as well as the authority to make it, must be closely scrutinized.... Because such a contract has the effect of extinguishing pro tanto an undoubted power of government, both [the promise to cede an aspect of sovereignty] and the authority to make [such a contract] must clearly and unmis- 
robustly, the express delegation doctrine might itself have been used to avoid the contract at issue in Winstar. Congress had not explicitly granted the Federal Home Loan Bank Board ("FHLBB") the power to assume the risk that Congress might pass more stringent standards for savings and loans in the future. Instead, a plurality found that the doctrine was inapplicable because a promise by the government to pay damages if it changed the law was not an infringement on sovereignty. Moreover, a majority of the Justices were convinced that the express delegation doctrine was satisfied in any event because the statute creating the FHLBB authorized it to "make contracts." express delegation doctrine.

To summarize, both doors opened by Chief Justice Taney have been slammed shut. The Court has come full circle back to Chief Justice Marshall's understanding that regulatory contracts are inviolable. ${ }^{60}$ We will draw upon the example of the recent regulatory con-

\footnotetext{
takably appear, and all doubts must be resolved in favor of the continuance of the power.
}

Id.

59 Winstar, 518 U.S. at 890 (plurality opinion) (maintaining that the bank regulators "had ample statutory authority to ... promise to permit respondents to count supervisory goodwill and capital credits toward regulatory capital and to pay respondents' damages if that performance became impossible"); see id. at 923 (Scalia, J., concurring) ("[W] hatever is required by the 'express delegation' doctrine is to my mind satisfied by the statutes which the principal opinion identifies as conferring upon the various federal bank regulatory agencies involved in this case authority to enter into agreements of the sort at issue here." (citation omitted)).

${ }^{60}$ In Yankee Atomic Electric Co. v. United States, 112 F.3d 1569 (Fed. Cir. 1997), cert. denied, 524 U.S. 951 (1998), the Federal Circuit avoided imposing liability on the government under Winstar by holding that the congressional action that allegedly constituted the breach of contract was a "public and general" act, which removed it from the category of actions that could give rise to a damages claim for breach. The problem with this escape route is that the congressional action at issue in Yankee Atomic seems, if anything, less public and general than the action held to constitute a breach in Winstar, that is, the passage of certain sections of FIRREA.

Yankee Atomic sued the United States for breach of contract, claiming that Congress's recent imposition of a decontamination assessment upon Yankee Atomic constituted a violation of various contracts entered into by the United States and Yankee Atomic in the 1960s. Under those contracts, the government provided Yankee Atomic with uranium enrichment services that Yankee Atomic required for its operations. Although these enrichment contracts did not address the issue of any future decontamination regulation or taxation, the claims court, applying Winstar, had held that the decontamination assessment was a breach of an implied term in the enrichment services contracts. The Federal Circuit sidestepped the claim court's questionable contractual interpretation and instead held that the assessment fell within the "public and general" exception to governmental liability because Congress acted "for the purpose of solving the decontamination and decommissioning of uranium enrichment facilities (i.e., the legislation was passed for the benefit of the public)." Id. at 1574. But the same could be said of the legislation at issue in Winstar: if the decontamination assessments could 
tract controversies to demonstrate that this understanding is wrong.

\section{CAPTURE, COMPROMISE AND CONTROLIING OPPORTUNISM: THE FUNCTIONS OF REGULATORY CONTRACTS}

While all regulatory contracts seek to stabilize, if not also to dictate, a particular political outcome, the reasons for seeking stability may differ. One might seek stability to secure the benefit of private party capture of public governance, to seal a compromise that protects both the current government actors and private parties from the possibility of greater losses in the future, or to protect private parties from the risk of government opportunism. ${ }^{61}$ These categories-capture,

be characterized as for the public benefit, FIRREA surely could also be characterized this way. To put it mildly, it is difficult to reconcile Winstar and Yankee Atomic, and, tellingly, the Federal Circuit never really attempted to do so.

Kyle Logue has argued that the government should be forced to pay damages for revoking or modifying tax law provisions upon which taxpayers have relied. See Logue, supra note 3, at 1183 (proposing expectation damages as an appropriate measurement). Building on the logic of Winstar, Logue sees tax legislation designed to create incentives as a form of regulatory contract. Logue argues that requiring the government to pay damages for "breaching" the promises of stability he would read into tax law makes sense for the same reason that it makes sense to award damages for breach of other regulatory contracts-the guarantee of performance or damages upon breach would lower the ex ante cost to the government of inducing the desired behavior on the part of private actors. See id. at 1139 (arguing that the government's failure to guarantee grandfather treatment may require that it pay taxpayers more to compensate them for the risk of tax transactions).

Logue's analysis is quite interesting, but in our view it wrongly assumes that most or even almost all regulatory contracts will fall within what we call the opportunism protection category rather than the capture or compromise category. See id. at 1146 (describing governmental opportunism). Indeed, interest group capture of the legislature is particularly likely in the context of tax incentive legislation, where the stakes regarding specific tax code incentives are very high on a per capita basis for small interest groups and relatively low for the general public. SeeMANCUR OLSON, THE LOGIC OF COLIECTIVE ACTION: PUBLIC GOODS AND THE THEORY OF GROUPS 147-48 (1971) (distinguishing the power of industry groups to compel tax and other revisions from the inability of the business community as a whole to effectuate them). Moreover, although this is not Logue's intent, his extension of Winstar's logic demonstrates just how inconsistent with democratic principles Winstar's premises are. Beyond tax legislation, all entitlement legislation-social security, welfare, Medicaid, and Medicare-induce reliance and thus may involve an implicit promise of regulatory stability. Indeed, it is difficult to imagine legislation upon which citizens do not rely in making financial planning decisions. If, however, almost every change in law triggered an obligation by the government to pay damages, the flexibility of a majority to change any law would be significantly restricted. See discussion infra Part IV.B (maintaining that regulatory contracts are a form of legislative entrenchment); see also Daniel S. Goldberg, Tax Sub. sidies: One-time vs. Periodic: An Economic Analysis of the Tax Policy Alternatives, 49 TAx L. REV. 305, 324-25 (1994) (advocating compensation for retroactive regulatory change, and assuming that tax incentive regulation generally falls within the category of opportunism protection). 
compromise, and opportunism protection-are not mutually exclusive. For example, in some sense all capture and compromise contracts may also be said to protect against opportunism by the government or its agents. Moreover, we do not believe it makes much sense to speak of the motives of entities. ${ }^{62}$ Some agency officials in the decision-making chain or members of Congress voting on a regulatory contract may have been unduly influenced while others may support the contract as a legitimate compromise of competing interests. Finally, even if we could characterize some contracts as falling exclusively within one category as opposed to another, we have no confidence $^{63}$ that, ex post, a court (or anyone else) could correctly identify which category applies.

Why then bother to separate for purposes of normative discourse what we do not believe can be separated in practice? Consider: If all three purposes are normatively unworthy of support, then the case for supporting and enforcing regulatory contracts would be significantly weakened, if not destroyed. On the other hand, if one or more of these purposes seems normatively attractive, then the case for enforcing at least some, if not all, regulatory contracts would be strengthened. In addition, we would have some measure by which to assess the various methods of sorting valid from invalid contracts: How well does each method support the worthy contract while discouraging the rest?

\section{A. Capture Contracts}

Congress enacted virtually all administrative agency statutes in response to claims by a portion of the electorate that the broader "public interest" mandated external policing of industry conduct. In the prototypical New Deal or post-New Deal administrative agency statute, Congress pronounced general public interest goals for industry regulation and then broadly delegated authority to an expert regulatory agency to implement those goals. Agency regulators were supposed to be sufficiently detached from industry to the extent that they could and would force the industry to remedy the problems that had spurred government intervention in the first place.

${ }^{62}$ In this, of course, we are far from being alone. See, e.g., Kenneth A. Shepsle, Congress Is a "They, "Not an "It": Legislative Intent As Oxymoron, 12 INT'L REV. L. \& ECON. 239,250 (1992) (using public choice theory to explore some of the conceptual problems in speaking of "legislative intent" in statutory interpretation).

${ }^{63}$ See discussion infra Part III.A. 
According to "capture" or "public choice" political theorists, ${ }^{64}$ however, government regulation does not work this way in practice. Instead, well-organized interest groups-most notably the targets of prospective regulation-often work to secure provisions in regulatory statutes that leave key decisions in the hands of agency regulators. The interest groups then exploit their power with key legislators to secure case-by-case legislative interventions in agency decision making. In addition, they foster bonds with agency regulators by, inter alia, providing agencies with key information, hiring former agency personnel, developing personal relationships through lobbying contacts, and supporting the continued funding of regulatory programs in which the regulators have developed human capital.

In "captured" agencies, agency regulators do not act as "armslength" representatives of some larger "public interest" in their interactions with regulated industries. Instead, government officials work to advance the agenda of current firms in the industry by formulating regulations that benefit or at least do not substantially burden the industry. In the most malignant capture account, the captured regulatory agency enables an industry to bar new entrants and extract monopoly rents so that consumers are materially worse off with regulation than without it. Capture of this sort, theorists claim, is particularly likely when an agency is charged with regulating only a single industry (for example, the FAA and the airline industry).

Capture accounts sometimes focus solely on the legislature rather than on the regulatory agencies. Where a narrow interest group is especially strong in the legislature, it may not need to win favorable outcomes for itself "behind the scenes" in a regulatory agency. Instead, powerful groups sometimes can secure direct, specific giveaways in legislation itself. At least on some accounts, legislatively mandated agricultural subsidies-subsidies that benefit only a few large firms and seem to have no conceivable broader public interest rationale-are prime examples of legislative capture. ${ }^{65}$

Capture is, of course, an imprecise and controversial theory.

${ }^{64}$ For a good overview of the public choice literature, see DANIEL A. FARBER \& PHIIIP P. FRICKEY, LAW AND PUBLIC CHOICE: A CRITICAL INTRODUCTION (1991).

${ }^{65}$ See Sidney A. Shapiro, Keeping the Baby and Throwing Out the Bathwater: Justice Breyer's Critique of Regulation, 8 ADMIN. L.J. AM. U. 721, 726 (1995) ("The lack of a convincing rationale suggests that [agricultural] subsidies are the product of public choice politics, which is confirmed by political analysts.").

${ }_{66}^{66}$ For thoughtful assessments of public choice/capture models of politics, see Steven P. Croley, Theories of Regulation: Incorporating the Administrative Process, 98 CoLUM. L. REv. 1, 34-56 (1998); Einer R. Elhauge, Does Interest Group Theory Justify More Intrusive 
The word itself suggests undue or illegitimate industry influence, but it is possible to speak of illegitimate interest group influence only if one has a coherent normative baseline defining legitimate interest group influence. Moreover, even if one has such a normative theory, it may be difficult to apply the theory in practice to the messy realities of political policymaking. As numerous critics of capture or public choice accounts have noted, capture accounts tend to avoid the complexities of real life by oversimplifying the motives of government decision makers. ${ }^{67}$ In other words, legislators and agency officials sometimes act out of motivations other than a desire to distribute benefits or "rents" to narrow interest groups.

These problems notwithstanding, the capture account of regulation embodies a basic truth about regulatory contracting: sometimes legislators or agency officials or both agree with regulated firms about what the content and scope of a regulatory regime should be. Where this is true, both legislators and regulators as well as the regulated may reasonably fear that political changes will disrupt their ability to realize their shared vision of the "best" regulatory regime. Such political change may take the form of a new assertiveness by legislators committed to a less pro-industry, more "public interest" regulatory agenda. Such shifts in legislative interest and activity may result from any number of sources: increased or better focused lobbying by constituents or groups critical of the perceived coziness of regulators and regulated firms; the impending possible election of new legislators or a new legislative leadership with weaker ties to industry and stronger ties to non-industry constituencies; or simply the desire of a "political entrepreneur" within the legislature to find an issue that might generate favorable popular press and attention. Pressure for regulatory change may also result from political change within the executive

Judicial Review?, 101 YALE L.J. 31 (1991) (examining proposals to make judicial review less politically deferential in light of interest group influence); Daniel A. Farber \& Philip P. Frickey, The Jurisprudence of Public Choice, 65 TEX. L. REV. 873 (1987) (discussing special interest groups and the question of whether legislatures can legitimately formulate public policy). Administrative agency-sponsored efforts at deregulation pose a significant challenge to the capture theory. See Joseph D. Kearney \& Thomas W. Merrill, The Great Transformation of Regulated Industries Law, 98 COLUM. L. REV. 1323, 1365-69 (1998) (chronicling agencies' deregulatory steps in response to political pressure).

See, e.g., Daniel A. Farber, Free Speech Without Romance: Public Choice and the First Amendment, 105 HARv. L. REv. 554, 557 (1991) ("Public choice theory is useful, but it cannot purport to be more than a partial explanation for political behavior."); Edward L. Rubin, Beyond Public Choice: Comprehensive Rationality in the Writing and Reading of Statutes, 66 N.Y.U. L. REV. 1 (1991) (arguing that the public choice theory, while not invalid, is limited in its applicability). 
branch, most dramatically the election of a new President representing a different coalition of voters with different ideological commitments.

Regulatory contracts may provide legislators, regulators, and regulated firms with a means to entrench their shared regulatory vision against the possibility of such political change. By entering into binding contracts with regulated firms whereby the "government" promises not to change the regulatory status quo, regulators can raise the costs of any legislative or executive branch initiatives to restructure the regulatory regime. In so doing, regulators may fend off or at least slow any such initiatives.

The problem in using regulatory contracts as a means of entrenchment is that, in order to be legally binding, the contracts cannot contain only a unilateral promise by the government to provide a benefit-here, insurance against regulatory change. Rather, the contract must at least resemble a mutual exchange in which the industry gives something of value-in contract doctrine terms, considerationto the government in return for the promise of insurance against regulatory change.

Precisely because they share the viewpoint of industry, legislators or regulators or both in the capture scenario may not wish to bargain for industry commitments that will impose substantial costs on industry. Instead, they may favor contractual promises by industry that both parties know will not be enforced in practice, will not cost the industry much, or, at the extreme, will call for actions that would be in the industry's interest even in the absence of a governmental promise of insurance against regulatory change. The trick for regulators and regulated entities in the capture scenario is to design regulatory contracts so that industry appears to be giving up a great deal to advance nonindustry, public interest objectives. Capture contracts thus are premised on a deception: that the industry has provided the government (as opposed to the government actors) with valuable consideration in exchange for the government's promise of regulatory stability.

In recent years, certain firms within the electric power industry and the savings and loan industry have claimed that they entered into regulatory contracts with agencies, which the government subsequently breached. Formerly regulated monopolists in the electric power industry claim that state regulators implicitly guaranteed them a customer base during the era when electricity was thought to be a natural monopoly, and that, based on that guarantee, the electric power companies had made infrastructure and other investments. 
The state regulators later adopted a deregulatory agenda, opening electricity markets to competition and leaving the formerly regulated monopolists with "stranded costs." The state regulatory agencies never expressly guaranteed to compensate former monopolists in the event of deregulation, but the electric power companies contend that such a contractual guarantee was implicit in the course of dealing between regulators and the regulated monopolies. ${ }^{68}$

Certain savings and loan banks claim that the federal bank regulators induced them to merge with or to acquire insolvent thrifts in return for a promise to forebear enforcing stringent loan loss requirements against the resulting merged entities. These alleged "forbearance" assurances, which Congress never expressly authorized and which were never expressly given by regulators, allowed the savings and loan banks to maintain huge outstanding liabilities based on minimal cash reserves ${ }^{69}$. After the financial disruption caused by such aggressive lending had become painfully apparent, Congress passed FIRREA, a comprehensive reform statute that, among other things, forbade the federal regulators from allowing any financial institution to maintain low loss reserves. The institutions that claimed to have received implicit forbearance assurances sued, seeking millions of dollars in damages. ${ }^{70}$

${ }^{63}$ See J. Gregory Sidak \& Daniel F. Spulber, Deregulatory Takings and Breach of the Regulatory Contract, 71 N.Y.U. L. REV. 851, 879-91 (1996) [hereinafter Sidak \& Spulber, Deregulatory Takings] (discussing regulators' obligations to compensate utilities for regulatory changes); J. Gregory Sidak \& Daniel F. Spulber, Givings, Takings, and the Fallacy of Forward-Looking Costs, 72 N.Y.U. L. REV. 1068, 1093-96 (1997) [hereinafter Sidak \& Spulber, Givings] (examining whether the government has implicitly compensated regulated firms for the negative impact of new policies). The former monopolists have advanced contractual compensation claims in rate-setting hearings before state legislatures, administrative agencies, and most recently before the courts. The local telephone service monopolists are now making analogous arguments in response to the deregulation of the telecommunications industry. But see William J. Baumol \& Thomas W. Merrill, Does the Constitution Require That We Kill the Competitive Goose? Pricing Local Phone Service to Rivals, 73 N.Y.U. L. REV. 1122 (1998) (arguing that Sidak's and Spulber's claims lack merit).

${ }^{69}$ It bears noting, however, that Congress certainly could have intervened to stop agency deal-making. On one account, the incentive structure of members of Congress-and in particular the fact that "individual legislators are not seen by their voter as playing a role" in a banking crisis and thus "are not penalized for letting the problem grow"-explains why Congress refused to buck the power of the thrift industry and instead allowed or even encouraged regulators to pursue permissive loan loss reserves policies. Thomas Romer \& Barry R. Weingast, Congress: The Genesis of the Thrift Crisis, 2 STAN. L. \& POL'Y REV. 37, 45 (1990).

${ }^{70}$ In some cases, they even sought billions of dollars. See Margaret Cronin Fisk, "Winstar" Litigants Bet on Future Damage Awards, NAT'L L.J., Jan. 11, 1999, at A19 (“II]n goodwill lawsuits [by thrifts] against the federal government... [t] he amount of dam- 
The criticism of these particular alleged regulatory contracts is that these contracts, assuming they exist at all, simply reflect agency capture. ${ }^{71}$ Indeed, the electricity, savings and loan, and a number of other controversial regulatory deals were entered into by agencies that fit the public choice theorist's prototypical candidate for agency capture: the agencies in question all had jurisdiction over only a single powerful industry and thus over time came to rely strongly on the patronage of that industry. ${ }^{72}$ Moreover, the agencies did not have highly

ages claimed is enormous. For example, Glendale Federal Bank ... is claiming damages of nearly $\$ 4.5$ billion."); Stephen Labaton, The Debacle That Buried Washington: Long After the $S \mathcal{E} L$ Crisis, Courts Are Handing Taxpayers a New Bill, N.Y. TIMES, Nov. 22, $1998, \S 3$, at 1 (explaining that thrifts' claims against the federal government for breach of contract could amount to $\$ 50$ billion). The New York Times article also explained that in the wake of Winstar, the federal government faces huge damage claims for breach of regulatory contracts from, not just the thrift industry, but other industries as well:

[O]ther industries are looking for ways to make use of the [Winstar] precedent....

Lawyers representing electric utilities, telecommunications companies and developers of low-income housing have begun filing lawsuits, and health care lawyers say they may be next. Initial successes indicate that taxpayers may end up facing yet more bills. . . . In all, utilities have pending claims of an estimated $\$ 50$ billion.

Id. at 12.

71 For depictions of the former utility monopolists (and their shareholders) as having captured regulators or, at least, as having received adequate compensation for the investment risks they took, see Oliver E. Williamson, Deregulatory Takings and Breach of the Regulatory Contract: Some Precautions, 71 N.Y.U. L. REV. 1007 (1996) (responding to Sidak \& Spulber, Deregulatory Takings, supra note 68, and arguing for a variable degree of compensation for stranded costs). Professor Macey argues that the Winstar and Winslar-type merger transactions reflected the undue influence of thrifts on bank regulators and that the mergers effectively "transferred considerable wealth from a highly disaggregated group-the U.S. taxpayers, who were the ultimate guarantors of the [federal deposit] insurance fund-to the highly concentrated and politically wellconnected creditors and acquirors of failed thrifts." Jonathan R. Macey, Winstar, $B u$ reaucracy and Public Choice, 6 SUP. CT. ECON. REV. 173, 189 (1998). Macey's basic point is that the mergers allowed the troubled thrift industry and its inadequate regulatory apparatus to continue longer than was economically sensible, and that had the thrift industry been allowed to fail earlier, the government bailout would have been much less expensive than was the case. The availability of government deposit insurance meant that the owners of the thrifts had every incentive to stay in business and keep making questionable loans despite the substantial risk that doing so would ultimately result in even greater net unpaid debts for the thrifts. See id. at 183 ("[S] hareholders of insured depository institutions have incentives to take risks as their equity position deteriorates: losses will be disproportionately borne by the debt-holders (including the [federal insurance fund]) while gains will accrue to the shareholders.").

${ }^{72}$ See John P. Dwyer, The Pathology of Symbolic Legislation, 17 ECOLOGY L.Q. 233, 309 (1990) (arguing that agencies are "vulnerable to capture" when they "regulate[ ] a single industry"); Jonathan R. Macey, Organizational Design and Political Comtrol of Administrative Agencies, 8 J.L. ECON. \& ORG. 93, 93-94 (1992) (suggesting that agencies regulat- 
organized public interest group outsider "clients" or constituencies that might check industry influence-as, for example, the EPA has in national and state environmental organizations. And at least in the hindsight view of some prominent observers, both the former electricity monopolists and the savings and loan banks who enjoyed forbearance assurances received unduly favorable-from the broader public interest view, indefensibly favorable-treatment under the terms of the alleged regulatory contracts.

ing multiple industries are less susceptible to capture than agencies regulating a single industry); Bradford C. Mank, Superfund Comtractors and Agency Capture, 2 N.Y.U. ENVIL. L.J. 34, 50 (1993) (asserting that the EPA is unlikely to be captured because it regulates multiple industries).

${ }_{73}$ Another example of a capture regulatory contract may be one between the DOI and oil companies regarding offshore oil and gas exploration rights. The Outer Continental Shelf Lands Act ("OCSLA"), codified at 43 U.S.C. $\$$ 1331-1343 (1984), passed in 1953, authorized the DOI to lease the rights to explore for oil and gas in the outer continental shelf. The standard OCLSA lease did not state that the lease precluded future environmental regulation that might limit or delay exploration; quite the contrary, the leases contained language that appeared to make the leases subject to any new regulation. The leases provided that they were subject to "all other applicable statutes and regulations." Marathon Oil Co. v. United States, 177 F.3d 1331, 1336 (Fed. Cir. 1999). The Federal Claims Court has read this language to include all other applicable regulations in existence at the time the lease was issued, see Conoco, Inc. v. United States, 35 Fed. Cl. 309, 322 (1996) ("The clause referring to 'all other applicable statutes and regulations' makes no mention of future or subsequent legislation ...."), rev'd by Marathon Oil Co. v. United States, 177 F.3d 1331 (Fed. Cir. 1999), but one could easily read the same language as including all applicable regulations-both existing and future.

In the early 1980s, the Reagan Administration's Department of Interior entered into leases with oil companies for exploration rights off the shore of North Carolina. In 1990, in response to environmentalist concerns and the lobbying of a wide range of North Carolina constituencies, Congress passed the Outer Banks Protection Act ("OBPA"), Pub. L. No. 101-380, § 6003, 104 Stat. 555 (1990) (repealed by 33 U.S.C. $\S 1753$ (c)(1) (1994)), which imposed a temporary moratorium on proposed exploration off the North Carolina coast until an environmental review board had examined the potential environmental impacts of that exploration. The oil companies responded by suing the United States for breach of contract, claiming that OBPA would either prevent them from obtaining DOI approval for any specific exploration plan or, at a minimum, would greatly delay their receipt of such approval. See Edward A. Fitzgerald, Conoco, Inc. v. United States: Sovereign Authority Undermined by Contractual Obligations on the Outer Continental Shelf, 27 PUB. CONT. L.J. 755, 758-64 (1998) (reviewing comprehensively the history of the offshore exploration controversy).

In an opinion relying on the Federal Circuit's decision in Winstar, and anticipating the Supreme Court's affirming opinion, the Federal Claims Court in Conoco held that the OCSLA leases in question had implicitly allocated to the United States the role of insuring the oil companies against any economic losses resulting from the imposition of any new regulation restricting oil exploration. See Conoco, 35 Fed. Cl. at 324 (finding that changes in federal policy on environmental regulation cannot "subvert the parties' mutual assent, reduced to writing and memorialized in contract"). The Federal Circuit reversed the claims court's opinion on causation grounds, namely that the 


\section{B. Compromise Contracts}

The capture scenario notwithstanding, it is certainly the case that powerful government actors in the legislature, the executive branch, and regulatory agencies sometimes have a much more pro-regulatory, "public interest" agenda than the regulated industries would like." In certain presidential administrations, for example, a central dynamic has been regulatory agencies advocating more controls on industry, and fierce legal and political resistance by industry. In such cases, of course, the battling government actors and industry cannot use regulatory contracts to entrench a shared regulatory vision because they have none.

However, where the dominant political actors in Congress, the executive, or regulatory agencies are engaged in political or legal battles with regulated industries, regulatory contracts may appeal to both the government actors and industry as a way of entrenching a compromise between their competing regulatory visions. A compromise contractual solution presumably would require fewer concessions by an industry than it would be forced to make if it were to lose its political struggle with the proponents of regulation. At the same time, the compromise contract would provide for greater industry concessions than proponents of "public interest" regulation in government would be able to secure if they were to lose their political battles with industry. ${ }^{74}$

congressional moratorium on exploration was not the but-for cause of the delay in exploration because the State of North Carolina independently had exercised its legal rights under the Coastal Zone Management Act to block the issuance of the necessary regulatory permits to the companies. See Marathon Oil, 177 F.3d at 1339 (finding that North Carolina's objection to granting certification was based on the inadequacy of information supplied by Mobil and noting that the state action appeared independent but that the issue was not raised on appeal).

The Federal Circuit thus largely sidestepped the contractual interpretation issues addressed by the claims court. See id. (repeatedly emphasizing the narrow scope of the court's decision). It is not obvious that the DOI officials who approved the OCSLA leases had the intent to insure the oil companies against regulatory change. But even if they did have that intent, it is not clear that intent should receive judicial recognition, at least in the absence of both an express congressional authorization for DOI officials to provide the oil companies with regulatory insurance and any explicit mention of such insurance in the contracts at issue. According to many commentators, and indeed many legislators in Congress during the time in which the OCSLA leases were consummated, the DOI was dominated by the oil industry with which it was ostensibly negotiating. See Fitzgerald, supra, at 794 (citing legislative history in which members of Congress express concern about oil industry power).

${ }^{74}$ We do not mean to suggest that government actors and private parties will measure risk with equal accuracy. Indeed, there are good reasons to believe that they will not. See infra notes $\mathbf{1 6 9 - 7 8}$ and accompanying text (discussing how private parties 
Compromise regulatory contracts will be particularly appealing to government actors who are risk averse-that is, who weigh downside risks of continued political battle more heavily than upside risks. One reason that government actors may be risk averse is that the proregulatory constituencies they represent, for whom they are agents, are themselves risk averse. Standard economic theory would predict that advocates for aggressive "public interest" regulation in the electorate may well be risk averse as to the worst possible future outcomes of a contractually unconstrained political process. In the realm of monetary or market risk, an investor can diversify against risk-essentially self-insure-by investing in multiple enterprises that are likely to fare differently under the same market conditions. ${ }^{75}$ Hedging, however, is not really an option for environmentalist or public health advocates. Because they cannot self-insure against a terrible overall political loss for the cause or issue they believe in, advocates of regulation may direct their supporters in government to remove issues they care about from the political battlefield by striking a long-term compromise deal with industry.

Even in the absence of risk aversion, advocates of regulation in the electorate may favor contracting out of political battles with certain companies or industries to make available more lobbying and other resources to devote to political battles with other companies or industries. Given their need for financial resources to lobby effectively and their perennial shortages of such funds, public health and environmental advocates may conclude that contracting out of political change with selected companies or industries is a rational resource conservation strategy.

For their part, the motivation of industry actors in embracing compromise contracts may also be complex. Some industry actors, particularly smaller businesses, may be risk averse with respect to the risk of unfavorable regulatory change in the future. Even where this is not the case, an industry actor may favor a compromise contract to save on the costs of continuing political battles. ${ }^{76}$ In addition, by pro-

are likely to have exclusive access to information relevant to measuring risks to the public, and that the utility curves of corporations are simple compared to those of the general population with which the government is concerned).

${ }^{75}$ See Lawrence Blume \& Daniel L. Rubinfeld, Compensation for Takings: An Economic Analysis, 72 CAL. L. REV. 569, 591 (1984) (discussing the role of risk aversion in investment decisions).

${ }^{76}$ Any analysis of whether compromise regulatory contracts offer a means by which interest groups can economize on political lobbying costs, however, is subject to some complications. On the one hand, to the extent that a long-term (say 20-year) compromise regulatory contract removes a politically contentious issue from ongoing po- 
viding greater certainty as to the future regulatory regime, regulatory contracts may allow a company to engage in more rational business planning. In the absence of regulatory certainty as to how many of the toxic chemicals produced by a chemical company might be banned, a chemical company might spend funds developing substitutes for all of its chemicals, including some that might well escape a ban if the industry fares well in future political regimes. If, instead, the company is assured by a regulatory contract precisely which chemicals will be banned and when the ban will occur, it can more easily focus its research and development.

In negotiating compromise contracts with an industry, proregulatory government actors may disfavor promises by the industry that the industry will make certain regulatory concessions far off in the future. Instead, the government actors may favor current or immediate performance by the industry as a quid pro quo for long-term governmental assurances of regulatory stability or compensation for regulatory change. Furthermore, government actors may insist upon current concessions by the industry that are, as a practical matter, irreversible. ${ }^{77}$

litical debate, it may save an interest group resources because the group need not continuously invest money in the political process to safeguard its interests. If the original tobacco deal had been consummated, the tobacco industry might have assumed that it could save $\$ 500,000$ per year in political investments that it otherwise would have expended in the absence of the long-term agreement. On the other hand, precisely because the compromise contract will cover a 20 -year period and therefore substantially affect the industry's future, the industry might find it worthwhile to expend a huge sum-for example, $\$ 10$ million-to ensure that the contract contains the most favorable terms as possible and is in fact consummated. For a detailed discussion of the behind-the-scenes machinations that led to the $\$ 8.2$ billion fee awarded to the lawyers for Florida, Mississippi, and Texas, and an explanation of how the tobacco companies protected themselves by negotiating a $\$ 500$ million per year annual cap on any and all fees to be paid to the lawyers (which translates into a 2-cents-a-pack increase in the cost of cigarettes), see Jim Oliphant, How Tobacco Fee Was Reached, AM. LAW., Dec. 24, 1998, at 1. The additional up-front lobbying cost of securing the compromise contract may equal or even outweigh the long-term savings in lobbying costs. For this reason, it is at best unclear whether regulatory contracts can be defended as efficient on the grounds that they economize on the overall resources devoted to political lobbying. See J. Mark Ramseyer \& Minoru Nakazato, Tax Transitions and the Protection Racket: A Reply to Professors Graetz and Kaplow, 75 VA. L. REv. 1155, $1157-58$ (1989) (pointing out that political action committees gave legislators over $\$ 6.7$ million to influence the 1986 Tax Reform Act, a figure that ignores the time and other resources those groups spent organizing themselves and lobbying assorted "opinion leaders").

${ }_{77}$ To illustrate why this would be the case, imagine that an industry that produces nine toxic chemicals offers environmentalist regulators the following deal: in $T_{1}$ (now) it will not eliminate any toxic chemicals, but in $T_{2}$ (some future time period) it will eliminate toxic chemicals 1-7. In return, the government will commit not to regulate toxic chemicals 8 and 9 in either $T_{1}$ or $T_{z}$ From the regulators' perspective, the fatal 
Compromise contracts, unlike capture contracts, are not inherently deceitful in that they entail a bargained-for, rather than pro forma, exchange of consideration. They are nonetheless normatively problematic, as a comparison of regulatory contracts and constitutional amendments can help illustrate. Compromise contracts operate much like a constitutional amendment: by binding (or at least financially burdening) the hands of future government actors, both constitutional amendments and regulatory contracts alike can protect, if not remove, certain issues from the ebb and flow of ordinary politics. ${ }^{78}$ Indeed, regulatory contracts have the same effect as a constitu-

drawback of the offer is that they may be out of power in $T_{2}$-a pro-business political majority may instead dominate regulatory politics in that time period. In fact, in the compromise contract scenario, it is the fear of that possibility that drives the government actors to the bargaining table. If a pro-business coalition were to take power in $T_{2}$ that coalition, using its control of the executive branch and Congress, might expressly release the industry from contractual obligations regarding chemicals 1-7 or simply ignore the industry's breach of the contract.

A contract that imposes heavy regulatory responsibilities on industry in the future, moreover, increases industry's incentive to fight for political change. Such a contract thereby increases the probability that the political shifts between $T_{1}$ and $T_{2}$ will favor business and not pro-regulatory constituencies. A contract that required the industry to immediately discontinue production of toxic chemicals $1-5$ as a quid pro quo for a government promise not to regulate chemicals $6-9$ in $T_{1}$ or $T_{2}$, by contrast, might remove (or at least lower) the industry's incentive for post-contract-formation politicking-particularly if the industry would have no reason to seek reversals of the bans once they were implemented because the industry had made the necessary, and presumably costly, changes in its production processes.

${ }^{78}$ Under longstanding judicial interpretations of the Takings Clause, the government normally can change its regulatory treatment of private assets other than land without violating the Takings Clause, even where such changes in regulatory treatment result in substantial reductions in the market value of the assets in question. See David A. Dana, Land Use Regulating in an Age of Heightened Scrutiny, 75 N.C. L. REV. 1243, 1250 64 (1997), and David A. Dana, Natural Preservation and the Race to Develop, 143 U. PA. L. REv. 655, 658-68 (1995), for a review of recent takings jurisprudence. Indeed, the Supreme Court has pronounced that, at least in heavily regulated areas of the economy (and most areas of the economy now are), private actors should presume that uncompensated regulatory change is always a significant possibility, at least where the assurance of constant regulatory treatment did not take the form of a judicially enforceable regulatory contract. See Ruckelshaus v. Monsanto Co., 467 U.S. 986, 1008-09 (1984) ("In an industry that long has been the focus of great public concern and significant government regulation, the possibility was substantial that the Federal Government, which had thus far taken no position on disclosure ... would find disclosure to be in the public interest."); see also Robert A. Graham, Note, The Constitution, the Legislature, and Unfair Surprise: Toward a Reliance-Based Approach to the Contract Clause, $92 \mathrm{MICH}$. L. REv. 398, 400 (1993) (explaining that, in the context of Contracts Clause cases, the courts have also assumed that an actor in a heavily regulated industry "realizes that the legal backdrop against which she conducts business is subject to change" and thus has no reliance-based claim for compensation in the event of regulatory change). We are generally sympathetic to this constrained reading of the Takings Clause for precisely the same reasons that we are generally unsympathetic to judicial enforcement of regu- 
tional amendment broadening the scope of the Takings Clause guarantee of just compensation. Yet the burdens imposed on the future by regulatory contracts are the result of a less elaborate and less comprehensive political process than that required for constitutional amendments.

The extraordinary procedural requirements for amending the Constitution ensure that the norms embodied in amendments reflect a fundamental consensus in the country. ${ }^{79}$ In contrast, compromise regulatory contracts may be consummated before there is any societal consensus on an issue-indeed, consummation can occur even when there is heated debate and division by partisan interest groups and perhaps general lack of attention, knowledge, or understanding by broad segments of the electorate. ${ }^{80}$ By removing issues from ordinary

latory contracts-notably, our view that impeding government actors in changing preexisting policies may result in the continuation of policies that reflect capture or lack of adequate information on the part of the original government decision makers. For a more detailed discussion of this view, see infra Part IV.A.

It is certainly possible that, even under the courts' constrained reading of the Takings Clause, a litigant could successfully style the breach of a judicially enforceable regulatory contract as a Takings Clause violation. A party that has received a judicially enforceable contract promising constant regulatory treatment arguably has an unusually distinct, reasonable expectation that the government will not change the relevant regulations without paying compensation; it is precisely the assurance of judicial enforceability that would make such an expectation reasonable. See Kaiser Aetna v. United States, 444 U.S. 164, 175 (1979) ("[The Supreme Court] has examined the 'taking' question by engaging in essentially ad hoc, factual inquiries that have identified several factors-such as the economic impact of the regulation, its interference with reasonable investment backed expectations, and the character of the governmental action-that have particular significance."); Penn Cent. Transp. Co. v. New York City, 438 U.S. 104, 124 (1978) (stating that examination of the takings question depends on several factors, including the economic impact of the regulation, its interference "with distinct investment-backed expectations," and "the character of the governmental action"). Thus, an expansion in the scope of those regulatory deals that the courts will recognize as contractually enforceable may translate directly into an expansion in the scope of the reach of the Takings Clause's guarantee of just compensation. Additionally, even if the courts in regulatory contracts cases decline to award damages based on a takings theory but do award damages for contractual breach, the practical effect will be the same as if the courts had formally expanded the scope of the Takings Clause's guarantee of just compensation.

79 This consensus, moreover, presumably reflects not just what a majority thinks is right for today, but also what it thinks is right for the future, since the position cannot be changed without extraordinary effort. See infra Parts III.A, III.B (discussing the relationship between constitutional and legislative entrenchment).

${ }^{80}$ Consider also that compromise regulatory contracts might be used by an industry as insurance against potential blowback from its own lobbying efforts. Once an industry places the regulatory regime under which it operates into play by seeking legislative relief (some form of deregulation), anything might happen. Therefore, before placing its regulatory status into legislative play, an industry might secure a compromise agency regulatory contract to minimize the downside risk of its own grander lob- 
politics before the formation of a fundamental public consensus, compromise regulatory contracts deny ardent believers on both sides of an issue the opportunity to advocate for noncompromise resolutions and the broader public thus never receives the education and enlightenment that (one might hope) results from open debate. Moreover, in the case of regulatory contracts consummated by a regulatory agency rather than the legislature itself, there is a real risk that important public controversies will be "resolved" and de-politicized for many years to come without any significant public attention. ${ }^{81}$ The same risk simply does not exist for constitutional amendments. ${ }^{82}$

bying plans. Indeed, this may have been what certain big-time cable companies did. Several such companies had regulatory contracts in place with the FCC-contracts designed to last 10 years - at the time Congress enacted legislation deregulating the cable industry. For an example, see the so-called "Social Contract" between Time Warner and the FCC, In re Social Contract for Time Warner, 11 F.C.C.R. 2788 (1995) (running from 1995 to 2000). For a discussion of the time-line for deregulation of the cable industry, see Michael I. Meyerson, Ideas of the Marketplace: A Guide to the 1996 Telecommunications Act, 49 FED. COMM. L.J. 251, 271 (1997). The industry will in fact be deregulated before those contracts are due to terminate. See Conversations with Margaret Egler, FCC Staff Attorney (Nov. 1998) (indicating that some cable industry contracts have termination dates that extend past the deregulation of the industry). The cable companies holding those contracts are too important in the industry not to have played a central role in the effort to get Congress to deregulate the industry. Their contracts may have been secured to eliminate the downside risk of putting cable regulation on the legislative agenda.

${ }^{81}$ A similar criticism may be, and has been, made about consent decrees between the government and a private entity that provide for remedies beyond those the government would be entitled to under existing law. See, for example, Michael W. McConnell, Why Hold Elections? Using Consent Decrees to Insulate Policies from Political Change, 1987 U. CHI. LEGALF. 295, 316-17, and other articles in that symposium issue.

${ }^{82}$ Even if compromise regulatory contracts were normatively defensible as "splitthe-difference" deals between pro-regulatory constituencies and industry, the reality of such deals is that they may not reflect the genuine preferences of either group. Instead, compromise regulatory contracts may reflect the self-serving preferences of the agents of pro-regulatory constituencies, ostensibly pro-regulatory government officials, and the agents of business corporations, corporate managers. There is no normative ground for honoring deals between, and in the service of, such unfaithful agents.

Due to the high cost of monitoring, pro-regulatory constituencies can only imperfectly monitor the actions of their agents. As a result, ostensibly pro-regulatory politicians and officials have some leeway to advance their personal interest at the expense of these constituencies' interests, and politicians' and officials' overwhelming personal interest is often thought to be to retain office. Striking compromise regulatory deals, even ones that fully informed pro-regulatory constituencies would reject, may help ostensibly pro-regulatory politicians and officials stay in power for two reasons. First, as discussed above, contracting out of political change normally will entail both substantial concessions by industry now and substantial concessions to industry later. To the extent that politicians can take advantage of this fact and highlight the current benefits and obscure the future costs, contracting out of political change may help politicians solidify their support with voters sympathetic to an activist regulatory state.

Second, contracting out of political change removes much of the incentive of con- 


\section{The "No Surprises" Habitat Conservation Plans, contracts entered} into by the United States with private landowners, and the failed attempt at a national tobacco deal are recent examples that come close to the compromise contract ideal. Both deals tried to use the mechanism of contract to resolve, or deflate, debates that reveal (or would reveal, if allowed to flourish) deep ideological divisions and conflicts in this country. ${ }^{83}$

tracting companies or industries to bankroll challengers to the incumbents in power. Incumbents already enjoy various advantages in our political system. Contracting out of political change might further strengthen the position of incumbents and increase the likelihood they will retain office.

For their part, corporate managers also have incentives to approve compromise regulatory contracts that their fully-informed principals, corporate owners and corporate shareholders, would disapprove. Particularly in larger corporations, the managers often operate with substantial autonomy with respect to the shareholder owners. Such managers may be risk averse, even if shareholders are risk neutral, with respect to the possibility of any future regulatory disaster for the corporation. See, e.g., John C. Coffee, Jr., Shareholders Versus Managers: The Strain in the Corporate Web, 85 MICH. L. REv. 1, 62 (1986) (" $[\mathrm{M}]$ anagers tend to be more risk averse than shareholders with regard to their corporation."). Many, if not most, managers are risk averse because much of their human capital is asset specific-that is, of value only in the context of their employing corporation. If the corporation fails or fares poorly, the managers are likely to suffer substantially. Finally, in many corporations, profit sharing plans operate so that the financial portfolios of high level managers are disproportionately invested in the stock of their employers.

${ }^{83}$ The tobacco story begins with the "settlement" of lawsuits brought by Attorney Generals against the tobacco industry. See Text of the Tobacco Deal [6/20], (visited Oct. 21, 1999) <http://ash.org/june97/6-20-97-1.html> [hereinafter Proposed Tobacco Industry Settlement, June 20, 1997] (consisting entirely of proposed federal legislation). The settlement was contingent on federal legislation. See Memorandum of Understanding, June 20, 1997 (on file with authors) (consisting of a one page, three paragraph document signed by the state attorneys general and tobacco industry representatives providing that the signers agree to lobby for the legislation embodied in the so-called Proposed Tobacco Industry Settlement). Although unreported by the press, the June 20 agreement between the attorneys general and the industry (and the separate settlements with the industry later reached by the states of Mississippi, Florida, and Texas) provided that the signing state officials would work to get Congress to enact federal legislation substantially similar to that advocated by the industry as a "settlement" of big tobacco's woes. See id.; Memorandum of Understanding, In re Moore ex rel. State of Mississippi Tobacco Litigation, July 2, 1997 [hereinafter Mississippi Settlement] (on file with authors). Indeed, the three individual state settlements provided that the industry would reimburse the states for expenses incurred in lobbying for federal legislation, and that the industry would pay reasonable attorney's fees for the time spent getting federal legislation passed. See Mississippi Settlement, para. 8:

In the event of the enactment of the Proposed Resolution [referring to the Proposed Tobacco Settlement of June 20, 1997] or other substantially equivalent federal program, the parties contemplate that the State of Mississippi and any other similar state [including, but not limited to, Florida and Texas] which has made an exceptional contribution to secure the resolution of these matters may apply to the panel of independent arbitrators for reasonable compensation for its efforts in securing the Proposed Resolution subject to an 
To take one of these examples, the proper scope of government efforts to protect endangered species on private land has been the subject of intense controversy. On the one hand, over the last twenty years, environmentalists and sympathetic public officials have increasingly come to recognize that efforts to protect endangered species cannot be limited to public land; large swathes of private land, too, must be part of effective conservation management. At both the federal and state level, Endangered Species Act legislation arguably authorized fairly intrusive developmental controls on private land, even though from an environmentalist perspective, the statutes, even if broadly construed, did not permit the sort of broad-based preservation planning that ideally would be employed to protect ecosystems under pressure from human development. ${ }^{84}$ From 1980 to 1992, however, the federal administration was ideologically opposed to aggressive developmental controls on private land. The election of President Bill Clinton changed that because he brought a Secretary with strong conservation credentials into the DOI for the first time in twelve years. Secretary Babbitt's inauguration at the DOI at least created the possibility of an ecologically-oriented preservation policy concerning private land.

At the same time that political circumstances for the first time made significant regulation on private land a feasible political possibility, a massive backlash against "zany" environmentalism erupted and threatened to erase even the possibility of continued preservation regulations on public, not to mention private, land. In Congress, the 1994 mid-term elections brought to power an ideologically conservative Republican leadership that proposed new legislation weakening the federal Endangered Species Act ("ESA") and requiring compen-

appropriate annual cap on all such payments.

Id. In effect, the tobacco industry had bought the lobbying efforts of state officials from the negotiating states. According to press reports, the lobbying expenditures of big tobacco aimed at securing passage of its regulatory contract were unprecedented, even for the tobacco industry. See, e.g., Saundra Torry, Tobacco Firms Put Much More into Lobbying, WASH. POST, Mar. 19, 1998, at Al ("The tobacco industry spent more than $\$ 19$ million on outside lobbyists last year-three times as much as in 1996 -most of it to press for passage of the proposed national tobacco settlement."). But those press reports understated the expenditures by failing to notice that the tobacco industry had committed to reimburse the states, and the private plaintiffs' lawyers representing the states, for their lobbying efforts in favor of the June 20 proposal, provided that Congress enacted it.

${ }^{84}$ See Bradley C. Karkainen, Biodiversity and Land, 83 CORNELL L. REV. 1, 198-221 (1997) (reviewing some of the limitations of the Endangered Species Act). 1998).

${ }^{85}$ Endangered Species Act of 1973, 16 U.S.C. $\S \S 1531-1540$ (1994 \& Supp. IV 
sation for almost any government regulation. In the state legislatures, property rights conservatives introduced and sometimes succeeded in securing passage of parallel legislation. ${ }^{86}$ Meanwhile, the federal courts, in particular the United States Supreme Court, signaled their hostility to endangered species protection in both statutory construction and constitutional Takings Clause cases. ${ }^{87}$ The significant opposition to preservation regulation by key actors in the legislatures and courts casts substantial doubt on the Clinton Administration's capacity to reverse the Reagan-Bush era practice of ignoring private land in preservation planning.

Faced with the possibility of an intense struggle over the regulation of private land, and the substantial possibility they would lose the struggle, Babbitt and pro-environmentalist regulators at DOI arrived at the split-the-difference solution of Habitat Conservation Plans ("HCPs"). In each HCP, the pro-environmental regulators received the landowners' commitment not to use the courts or legislature to

${ }^{86}$ See generally Robert L. Glicksman \& Stephen B. Chapman, Regulatory Reform and (Breath of) the Coniraci with Ámerica: Improving Environmental Policy of Destroying Environmental Protection, 5 KAN. J.L. \& PUB. POL'Y 9 (Winter 1996) (reviewing proposed property rights legislation); Joseph L. Sax, Takings Legislation: Where It Stands and What Is Next, 23 EcologY L.Q. 509 (1996) (same).

${ }^{87}$ See Babbitt v. Sweet Home Chapter, 515 U.S. 687, 708 (1995) (rejecting a facial challenge to a DOI regulation regarding the scope of protection for endangered animals against incidental habitat destruction, but emphasizing that the Court might reject the application of the regulation in specific cases); Lucas v. South Carolina Coastal Council, 505 U.S. 1003, 1030 (1992) (purporting to establish, in a plurality opinion, a qualified per se rule requiring compensation for stringent controls on land development).

${ }^{83}$ DOI officials and consultants themselves have portrayed "No Surprise" agreements and similar certainty-enhancing measures as a response to radical statutory proposals they believe would explicitly or effectively repeal the current framework of environmental laws. See, e.g., Blaine I. Green, The Endangered Species Act and Fifth Amendment Takings: Constitutional Limits of Species Protection, 15 YALE J. ON REG. 329, 370 n.201 (1998) ("Interior Secretary Bruce Babbitt has consistently been a strong proponent of habitat conservation planning, extolling its benefits to both landowners and species."); Joseph L. Sax, Using Property Rights to Attack Environmental Protection, 14 PACE ENVIL. L. REV. 1, 14 (1996) (reporting Sax's view, as counselor to Secretary Babbitt, that "these administrative innovations demonstrate[] that the ESA... can be protected vigorously... [thereby] protecting economic values for both private landowners and commodity users of the public lands. They... show that the ESA can be administered ... effectively and fairly, and need not be undermined by ill-conceived, grossly expensive, and unnecessary [statutory] compensation schemes"); Karin P. Sheldon, Habitat Conservation Planning: Addressing the Achilles Heel of the Endangered Species Act, 6 N.Y.U. ENVIL. L.J. 279, 281 (1998) ("Secretary Bruce Babbitt and the Fish and Wildlife Service ... are scrambling to promote the 'flexibility' of the [Endangered Species Act] and to create policy approaches that will lessen the likelihood of drastic legislative surgery on the Act."). 
fight the agency's efforts to set up a preservation program that encompassed some of their land. At the same time, the agency sanctioned the landowners' plans to engage in some development activities on their land that arguably, or sometimes clearly, violated current endangered species regulations. Even more importantly, given the real downside risk landowners faced, that in the absence of an HCP compromise they might face more, and not less, intensive preservation regulation in the future, landowners received long-term contractual commitments from the government that they would not be subject to any additional regulation, or, if they ever were, they would be fully compensated. ${ }^{89}$ HCPs thus represent contractual compromises of the current political dispute over preservation regulation that, as a practical matter, may severely constrain the terms on which future public debate regarding preservation regulation can take place. ${ }^{90}$

\section{Opportunism Protection Regulatory Contracts}

Operating at arms-length from industry, and representing non-

${ }^{89}$ For a good discussion of the guarantees afforded landowners and the political forces that compelled the grant of those guarantees, see Patrick Parenteau, Rearranging the Deck Chairs: Endangered Species Act Reforms in an Era of Mass Extinction, 22 WM. \& MARY ENVTL. L. \& POL'Y REv. 227, 284-93 (1998).

${ }^{90}$ Commentators generally have not claimed that the DOI's HCP contracts reflect capture. The DOI, however, has a long history of close-many would say, incestuousrelationships with the private interests it regulates. See GEORGE CAMERON CAGGINS \& ROBERT L. GLICKSMAN, PUBLIC NATURAL RESOURCES LAW \$ 16.01[1] (1990) (reviewing charges that the DOI is dominated by the industries it regulates); Michael C. Blumm, Public Choice Theory and the Public Lands: Why "Multiple Use" Failed, 18 HARV. ENVTL. L. REV. 405, 405-07 (1994) (same). One could imagine that, under the stewardship of a Secretary less "green" and less watchful than Babbitt, the HCP regulatory contracting program could evolve into a means of freezing into place very favorable deals for landowners. Monitoring by environmentalist and community groups might prevent such outcomes, but monitoring hundreds or even thousands of complex HCPs might well entail more resources than such groups could possibly muster. See Holly Doremus, Preserving Public Participating in the Era of Reinvention: The Endangered Species Example, 25 ENVIL. L.Q. 707, 712-15 (1999) (discussing the problem of meaningful environmentalist participation in reinventing programs such as DOI's HCP program); Warren L. Ratliff, The De-Evolution of Environmental Organization, 17 J. LAND RESOURCES \& ENVIL. L. 45 , 48-53 (1997) (addressing implications of decentralization of environmental regulation for representation of environmentalist interests).

One caveat regarding a political compromise account of the rise of HCPs is in order: the risks that the no-surprises guarantee is meant to redress are not only political ones, but also scientific ones that reflect, fundamentally, the rudimentary state of our ecological understanding. Political and scientific risks are inextricably intertwined in practice, but in theory at least, we might normatively assess the efforts to contract out of scientific risk differently from the way we assess efforts to contract out of political risk. 
industry constituencies, government actors might reasonably believe that in order to induce industry to make some socially beneficial investment, the government needs to promise stability with respect to the regulatory treatments surrounding that investment. For example, to get an industry to invest in inner-city neighborhoods, a state government might promise favorable tax treatment of the investment for the next twenty years. If such promises were not legally enforceable, however, the industry might fear that the government actors would induce them to make socially beneficial investments based on promises of continued favorable regulatory treatment and then renege.

As noted above, compromise contracts generally will call for current investments by industry of a sort that are costly for industry to reverse. $^{9 \mathrm{I}}$ For industry, it is just such investments that most pointedly raise the specter of government opportunism; industry, therefore, might be unwilling to make certain investments in the absence of the protection afforded by a regulatory contract. As a result, regulatory contracts entailing immediate and difficult-to-reverse industry investments may be either compromise contracts or opportunism protection contracts (or to an extent, both). For example, the landowners who received "No Surprises" assurances maintain, and some academic commentators agree, that their deals with the government are designed to prevent them from being taken advantage of by committing land to preservation that they might otherwise have developed and then, having made such costly concessions, being forced by "greedy" activist regulators to give up more (and later still more)..$^{92}$

Moreover, almost all, if not all, capture contracts could plausibly be labeled opportunism-protection contracts. For example, the former electricity monopolists claim, and some academic commentators agree, that their implicit regulatory contract with regulators reflected

91 See supra note 77 and accompanying text (explaining that in the absence of current concessions by industry, the pro-regulatory government actors would be running the risk that they would be replaced in a subsequent election before they realized the benefits of the contract).

${ }_{92}$ For statements of the view that DOI assurances are necessary to prevent government opportunism, see, for example, Fred P. Bosselman, The Statutory and Constitutional Mandate for a No Surprises Poligy, 24 ECOLOGY L.Q. 707, 718 (1997) (stating that "[a]ssurances agreements ... guarantee[] developers that they will only have to pay a certain amount for compliance even if the regulatory scheme changes after they have invested time and resources in the process described above"), and Barton H. Thompson, Jr., The Endangered Species Act: A Case Study in Takings E Incentives, 49 STAN. L. REv. 305, 371 (1997) (noting that assurance agreements are necessary to "ensure property owners prior to regulation that they will receive some level and form of compensation if the ESA ultimately limits use of their property"). 
nothing more invidious than their common sense need for some assurance that their investments of millions of dollars in infrastructure would not be followed by rate cuts that regulators might wish to put into place in order to score political points with electricity consumers. Similarly, the S\&Ls that allegedly received forbearance assurances claim, and again some academic commentators fully agree, that they would have been foolhardy to make the significant financial sacrifices requested by the government (taking over failed thrifts) if the government were not going to guarantee them some financial benefits in return. ${ }^{93}$

Enforceable contracts that promise regulatory stability are, of course, not the only method of protecting private parties from opportunistic behavior by the government ${ }^{94}$ The government's commitment is first and foremost guaranteed by the costs to the government of being seen as an entity whose word may not be trusted. As mentioned earlier, the costs in reputation-effects to the government of breaking its word are greatest when the promise is visible and specific. Thus, private parties may decrease the risk of governmental opportunism by getting the government to commit itself in writing, and by publicizing the fact and content of the government's commitment. ${ }^{95}$ The government could also insure the private party against the prospect that the government will act to deny the private party the benefit of the bargain by paying more money up front to get the private party to assume the risk of a change in government policy. That strategy might, however, make some deals too costly. Additionally, there is the hostage strategy. A regulator's promise to maintain a certain regulatory approach is strengthened whenever reneging on that promise

${ }^{93}$ See, e.g., Linda B. Coe, Note, Abrogation of Forbearance Agreements: Unauthorized by FIRREA and Unconstitutional, 59 GEO. WASH. L. REV. 157, 192 (1990) ("Honoring forbearance agreements continues to be in the public interest."); Steven J. Tsimbinos, Note, Forbearance Agreements To Consider Goodwill as Regulatory Capital: Binding Contracts Thrifts Should Recover, 73 B.U. L. REv. 451, 476 (1993) (advocating judicial recognition of regulators' forbearance assurances in order to "maintain private sector confidence in government contracts, and preserve[] the government's ability to seek the private sector's assistance in the future").

${ }_{94}$ The alternative means of controlling government opportunism, however, sometimes may entail greater transaction costs, and those greater transaction costs sometimes may be more than the parties would find it worthwhile to bear. Thus, we recognize that, at least in some contexts, the unavailability of regulatory contracting as an option to safeguard against government opportunism may mean that certain transactions simply do not take place.

${ }^{95}$ This strategy may work best where the industry invests in the retention of influential allies in dominant political institutions, such as maintaining good relations with important politicians who can "make a stink" about the government breach. 
would lead directly to greater government costs. This is so whenever the government has a continuing demand for the services or goods provided by the private party being asked to perform based on the expectation that the government will keep its side of the bargain. For example, "[i]f consumers have a growing demand for utility services that will require capital investments, their future demand can serve as a hostage to present commitments [to set compensatory rates of return on investment]. ${ }^{96}$ The risk of government opportunism may also be reduced whenever it is possible to reduce the stakes by opting for a series of small promises, each to be performed and paid for in turn, versus one large one. ${ }^{97}$

\section{Interlude: Where We Are Going and Why}

The existence of alternative means of reducing the risk of government opportunism does not mean that it is right to prohibit regulatory contracts as a method of achieving that goal. If the goal is valid, enforcing some regulatory contracts to achieve that goal may make sense, assuming, that is, that the cost of enforcing those contracts is not too great. For example, if the cost of enforcing regulatory contracts were to encourage the formation of capture and compromise contracts, the cost might well be too great, particularly given that other methods of preventing government opportunism exist. Indeed, we believe that there are other, even more serious costs, associated with enforcing any subset of regulatory contracts-costs which will lead us to advocate a doctrinal approach aimed at isolating regulatory contracts from other government contracts to hold all of the former

${ }^{96}$ Glenn Blackmon \& Richard Zeckhauser, Fragile Commilments and the Regulatory Process, 9 YAIE J. ON REG. 73, 100 (1992). This article offers a number of strategies available to regulators and industries to decrease the potential for government opportunism. It is noteworthy that the authors dismiss regulatory contracts, which they term "the most obvious approach," in a few concise sentences:

Regulators interested in strengthening commitment can find many potential approaches, though none are without cost. Perhaps the most obvious approach would be to make a commitment in the form of a contract. However, such a contract would have to account for a vast number of contingencies, many unforeseeable. In addition, the contract would be difficult and expensive to enforce.

Id. at 101. For a description of other methods of shoring up government commitment that have developed in the case of regulated utilities, see id. at 101-03.

${ }^{97}$ See Avinash K. Dixit \& BarRY J. Nalebuff, ThinkIng Strategically: ThE COMPETTIIVE EDGE IN BUSINESS, POLITICS, AND EvERYDAY LIFE 157 (1991) ("Honor among thieves is restored if they have to trust each other only a little bit at a time."). For a general description of other methods of making commitments credible, see $i d$. at 142-67. 
nonenforceable. ${ }^{98}$

First, however, we want to take seriously the idea that enforcing some subset of regulatory contracts to protect against government opportunism makes sense and consider what doctrinal approach might further that goal. If a doctrinal approach exists that would greatly reduce the formation of capture and compromise contracts, while still leaving room for the enforcement of some regulatory contracts (contracts that are more likely to be pure opportunism protection contracts), it is worth detailing for both practical and analytical reasons.

The practical reason is that any such approach would be an improvement over the Court's current approach, which we believe invites capture and compromise contracts and an all but limitless sale of sovereignty. This happens because the Court treats regulatory contracts as no more normatively problematic than contracts between private parties and therefore, finds them entitled to routine enforcement. Even more important, the Court justifies its willingness to enforce virtually all regulatory contracts largely in the name of preventing government opportunism. Thus, a doctrinal approach sensitive to the goal of preventing government opportunism would not only represent an improvement over current doctrine but would also have some chance, albeit not a great chance, of being adopted. ${ }^{99}$ In contrast, the more radical solution we advocate below, which is aimed at invalidating all regulatory contracts would require the Court to do a complete about-face.

Analytically, if no method of deterring capture or compromise contracts exists short of invalidating all regulatory contracts, and assuming we are right about the evils of capture and compromise contracts, the argument for invalidating all regulatory contracts is strengthened. Conversely, if capture and compromise contracts can be deterred through less drastic means, the argument for invalidating all regulatory contracts must rest on other grounds.

${ }^{98}$ See infra Part III.

99 Given how little respect was shown by a majority of the Justices in Winstar for the kinds of procedural requirements we advocate to deter capture and compromise contracts, we recognize that the chance of an about-face in the near term is slim. United States v. Winstar Corp., 518 U.S. 839 (1996). Nonetheless, given that a majority of Justices could not agree on an approach to regulatory contracts in Winstar, there is some reason to hope that an approach sensitive to government opportunism might influence some members of the Court. See supra Part I.B for a detailed discussion of the Winstaropinion. 


\section{PROTECTING SOVEREIGNTYTHROUGH PROCEDURE}

\section{A. The Virtues of Transparency}

After a regulatory contract has been formed-and, as we suggested above, even at the moment it is formed-whether the contract represents capture, compromise, or pure opportunism protection will be a question with multiple answers, all of which may seem plausible in most, if not all, cases. These categories may be separated for the purpose of discourse, as we have stressed. That does not mean, however, that there is an easy way to choose among them when it comes to characterizing what actually happened in any particular deal.

The preceding analysis does suggest at least two variables that might be used to answer the question whether a given contract was primarily a function of capture, compromise, or opportunism protection: (1) the extent to which the contract was formed during a period of impending political change, and (2) the extent to which the contract imposed burdens on the contracting private parties that, at the time of contract formation, appeared to be roughly proportionate to the burdens or costs imposed upon the private parties and to the broader public gains achieved thereby. If the contract in question was formed at a time of apparent long-term political stability with regard to the contract's subject, the contract probably represents an opportunism protection contract and not a capture or compromise contract. On the other hand, if the contract in question was formed at a time of widely-recognized political instability on the relevant question, the contract more likely represents capture or compromise, and not pure opportunism protection. Contracts that disproportionately favor the private contracting parties presumably reflect capture; more balanced contracts could be either compromise or opportunism protection contracts.

The problems with any exercise based on questions like those we have just posed should be readily apparent. How precisely would a court, or anyone, determine whether a period of time is one of political stability or consensus on an issue versus one of instability? While it may be true that indeterminacy inheres in every legal test, there is undoubtedly a continuum of indeterminacy and the questions above seem to rest at one extreme. To make the indeterminacy problem worse, any typing of a contract by a court is likely to happen years after the contract was formed when, because of political change or other factors, some powerful forces both within and outside of the government are likely to be claiming that the contract is unfair to the 
broader public interest and should not be enforced. If political change followed the contract formation, hindsight bias might easily lead a court to judge that the contract represented an effort to address the risk of political change even though, at the time of contract formation, the contracting parties may have foreseen only political stability. Similarly, because the contract ex post may seem to be a very good deal for industry and a poor one for "the public," hindsight bias might lead a court to find capture even though the contracting parties at the time thought they were striking a balanced, arms-length deal. To deter capture and compromise contracts, it is necessary for the parties to believe at the time the contract is formed that a court would be able to tell whether the contract reflects capture or compromise more than opportunism protection. Given the enormous uncertainty that would entail any ex post inquiry aimed at discerning capture or compromise, there is no reason to believe that contracting parties will hold such beliefs.

Upholding only those regulatory contracts that meet certain procedural requirements for their formation is a much more promising approach. The procedural requirements to which we refer focus on the level of openness, publicity, explicitness, or (as a one-word aggregation of all of these) transparency surrounding the formation of the contract and the terms of the contract itself. There is good reason to believe that the greater the transparency of the contract's terms and the political process surrounding the contract's formation, the less likely it is that the contract represents either capture or political compromise and the more likely it is that the contract represents pure opportunism protection. With respect to capture contracts, transparency in the political process would, at least in theory, allow noncaptured political actors representing majoritarian interests to stop the corrupt contracting process before it is ever consummated. Similarly, transparency in the compromise contract process would allow interests that regard the compromise as a sell-out or as a boon to selfserving risk-averse politicians to weigh into the debate and influence the political outcome. ${ }^{100}$ In contrast, because they are not attempts to sidestep current or looming political divisions, opportunism protec-

${ }^{100}$ Of course, there may be a down side to limiting the formation of regulatory contracts in this way: interest groups that otherwise would have stabilized political outcomes by contract might simply resort to alternative means, for example, increased campaign contributions. If those alternatives are themselves normatively undesirable, they too should be addressed by reform proposals, such as effective campaign finance reform legislation. 
tion contracts should be formed as readily under conditions of political transparency as under conditions of political non-transparency. For example, if a strong majority of the townsfolk wants to guarantee a racetrack a five-year tax break to encourage the racetrack's construction and the consequent increase in town tourism, transparency requirements should have no effect on the ability of the town to make that deal. Perversely, the thrust of Winstar-clearly the most important recent case regarding when regulatory contracts are enforceable-is to require less transparéncy, not more. This surely is a mistake that warrants immediate correction.

\section{B. Restoring and Supplementing Procedural Protections for Sovereignty}

The Supreme Court never articulated a clear functional justification for the particular procedural impediments it placed in the path of regulatory contracts. They were impediments to enforcing regulatory contracts, and nothing more needed to be said. This jurisprudential attitude is rooted in a natural law tradition that predates the Revolutionary War and was undoubtedly familiar to the framers of the Constitution. ${ }^{101}$ It is the attitude expressed by Lord Mansfield in Somerset in 1772: "the state of slavery is of such a nature, that it is incapable of being introduced on any reasons... but only by positive law.... It is so odious, that nothing can be suffered to support it, but positive law." ${ }^{102}$ Similarly, in cases in which the procedural protections of sovereignty were used to avoid contracts, the Court expressed the sentiment that contractual commitments that impeded the State's exercise of sovereign powers were so disfavored by natural (as opposed to constitutional) law that those commitments would be allowed to impede legislation only when the positive law clearly supported that reading of them and no other. Understanding this is important to understanding the demise of the unmistakability and express delegation doctrines. Once a majority of Justices stopped taking seriously the notion that awarding damages for breach implicated sovereignty, the unmistakability and express delegation doctrines lost their reason for being. They were bound to fall. Aside from the assumption that regulatory contracts ceded sovereignty, and that such was a bad thing, the cases expressed no opinion on whether-and if so, why-the re-

101 See ROBERT M. COVER, JUSTICE ACCUSED: ANTISLAVERY AND THE JUdICIAL PROCESS 8-28 (1975) (discussing slavery, natural law, and judicial positivism in the 18th century).

${ }^{102}$ Somerset v. Stewart, 98 Eng. Rep. 499, 510 (K.B. 1772). 
fusal to enforce the subset of regulatory contracts that failed the particular procedural hurdles built by the Court would advance the social welfare while the enforcement of contracts that failed these hurdles would not. ${ }^{103}$

It is our claim that these particular procedural rules can be justified by their ability to deter the formation and the enforcement of capture and compromise contracts. In addition, they are useful as default rules, which may promote more efficient trades by increasing certainty about what is being bought and sold. The default rule justification may be quickly stated, as it is tangential to our present purpose.

The default rule justification for the unmistakability rule is: Parties to any contract or deal-including deals between the government and private parties-sometimes fail to explicitly manifest their intent as to the terms of their deal. Where they so fail, courts employ default rules to approximate the parties' intent. If the default rule announced by the court is a clear and straightforward one, it assists parties in subsequent contract negotiations by putting them on advance notice of how their contracts will be interpreted in the absence of explicit provisions, and thereby indicating the explicit provisions they should take care to include in the contract. The existence of default rules facilitates efficient bargaining. Moreover, the unmistakability doctrine, which sets the absence of a government commitment of regulatory stability as the default, seems preferable to the alternative default rule: that in the absence of an explicit manifestation of intent, the courts will assume that the parties intended an enduring regulatory commitment on the part of the government. The unmistakability default rule is preferable because judging which legislative acts breach a contract is no simple matter, given the government's broad power to legislate and the myriad of ways that legislation might interfere with a contract. Insisting that the parties specify precisely what, if anything, the government is promising not to do would minimize the uncertainty created by ex post court review. Court review under the alternative default rule would seem to invite more uncertainty, not to men-

${ }^{103}$ In the Providence Bank case, one of the earliest unmistakability precedents, Justice Marshall did suggest that the unmistakability requirement is important to ensure notice to the "whole community" in a matter-the abandonment of the sovereign power-in which "the whole community is interested." Providence Bank v. Billings, 29 U.S. (4 Pet.) 514, 561 (1830). That passage, as well as the other cryptic comments by the Court on this topic, does not illuminate why greater notice is needed in the regulatory contracts arena than in other arenas of governance or, perhaps more importantly, what real difference that notice would make. 
tion a greater countermajoritarian role for the courts-something worthy of avoidance in its own right. ${ }^{104}$

The more important justification for the unmistakability and express delegation doctrines involves their potential to influence the dynamics surrounding dealmaking between government and private actors. Both doctrines lower the monitoring costs for parties not involved directly in the agency or legislative process of formulating regulatory contracts and thus, facilitate efforts by such parties to oppose politically the attempted formation of such contracts. Where regulatory contracts do not represent in fact a broad political consensus, such opposition is quite likely to be successful. Since both capture and compromise contracts are unlikely to represent a broad political consensus while pure opportunism protection contracts are likely to represent such a consensus, these devices would help deter the first two kinds of contracts, while encouraging the latter.

Consider a capture contract where a group of agency officials want to strike a highly favorable deal with an industry that imposes modest benefits on the industry in return for a highly valuable promise of stable regulatory treatment. In the absence of the express delegation doctrine, such a deal could be legally consummated without any express legislative authorization. ${ }^{105}$ The requirement of legislative authorization forces the agency to enlist the legislature in a program of contract formation, and it therefore serves to notify non-captured, public interest legislators of impending regulatory deals. So notified, they can organize to defeat the legislative authorization by raising questions about the public interest justification for regulatory contracting in the context of the particular agency and regulatory program at issue. Even if they cannot defeat legislative authorization, the concerned legislators are put on notice to oversee the agency receiving the authorization more closely than they otherwise might have.

${ }^{104}$ The unmistakability doctrine, like all plain or clear statement rules, constrains judicial discretion. It is thus ironic that Justice Scalia, the leading proponent on the Court of limiting judicial discretion through plain statement rules, advocates a toothless version of the unmistakability doctrine that would enhance judicial discretion to decide precisely what commitments the government had and had not made. See United States v. Winstar Corp., 518 U.S. 839, 920 (1996) (Scalia, J., concurring) ("In my view, the doctrine has little if any independent legal force beyond what would be dictated by normal principles of contract interpretation.").

${ }^{105}$ The express delegation cases left open the question whether "anything less than a clear and affirmative" legislative delegation of the authority to "contract[] away a power of regulation," Home Tel. \& Tel. Co. v. Los Angeles, 211 U.S. 265, 276 (1908), would ever be sufficient to permit a delegee to enter into judicially enforceable regulatory contracts. We believe the answer should be no. 
Furthermore, even where the legislature and the agency both are fully captured, the unmistakability requirement serves to notify constituencies who may not be represented in the agencies or legislature-but who still can wield political clout-of the impending formation of regulatory contracts and the consequent need to launch a lobbying effort to thwart that formation. For example, imagine that pro-regulatory, but highly risk-averse agency officials wish to enter into a compromise regulatory contract with an industry to secure certain regulatory concessions and cool political battles. If the officials can do so without entering into an express agreement with the industry, then they may be able to "close the deal" without any awareness on the part of less risk-averse, pro-regulatory constituencies. It is, to say the least, hard for outsiders to monitor unspoken and unwritten deal-making. If, however, the agency must secure explicit legislative authorization of at least its general plan in order to engage in regulatory contracting, and must incorporate the regulatory deal in an explicit, unmistakable rulemaking, then opposition groups are more likely to take notice and perhaps raise questions and rally support against compromise measures.

While the pre-Winstar procedural doctrines served to lower the monitoring costs for noncontracting parties and thus presumably played some role in deterring the formation of undesirable contracts, the doctrines did not go far enough. They did not ensure anything like full transparency in the regulatory contracting process. For one thing, it appears that the express delegation doctrine was never read to require that each specific agency promise purporting to impede future government action be a promise that the agency is expressly authorized by the legislature to make. Instead, at most what seems to have been required was unmistakable legislative authorization for the agency to enter into a particular type or category of regulatory contracts (e.g., authorization for the federal bank regulators to enter into forbearance agreements with thrifts, rather than authorization for specific forbearance agreements). A requirement of specific legislative authorization for each contract obviously would consume substantial legislative resources but such a requirement would make it significantly easier for constituencies (including legislators) to track and challenge the regulatory contracts that the agency might seek to enter.

Additionally, the pre-Winstar unmistakability requirement did not guarantee that the agency's contract with the private contracting party be made subject to public notice and comment before its final con- 
summation. Agency rulemakings can proceed, as a matter of statutory requirements, only after the public is given notice and time to comment. That requirement dramatically lowers monitoring costs for outside constituencies and thus helps them to participate effectively in policy formation. In contrast, the procedural protections put in place by the pre-Winstar Court fell far short of the public notice and comment required by the Administrative Procedure Act ("APA"). ${ }^{106}$ Thus, for the purposes of the unmistakability doctrine, regulators and an agency could enter into an unmistakable, express deal in a back room with no opportunity for public notice, let alone meaningful comment. Notice and comment requirements for regulatory contracts would add to the costs of agency contracting, but regulatory contracts formed by agencies are (or should be) rare enough, and the stakes for democratic governance seem high enough, that the costs of formalized public notice seem justified. The Court could interpret the APA to include regulatory contracts although we think that would be highly unlikely. Therefore, Congress should consider amending the APA to bring regulatory contracts under the notice and comment regime.

Another additional procedural requirement that the Court or Congress might adopt to deter capture and compromise contracts by fostering transparency is a liquidated damages requirement. Regulatory contracts without liquidated damages provisions should be unenforceable in court. This rule would minimize the moral hazard problem implicit in regulatory contracts and facilitate thoughtful democratic deliberation surrounding their formation. The moral hazard problem, simply stated, is that once the government has promised to insure the private party against the risk that the law will change, the private party has little incentive to worry about the social utility of his activities or investments. Thus, all full insurance contracts invite inefficient behavior, which is why one rarely sees full, as opposed to partial, promises to insure. A liquidated damages requirement might function in a manner similar to partial insurance, limiting the moral hazard problem. Perhaps most importantly, a liquidated damages provision would help the present majority focus on the costs it was about to impose on the future-costs likely to be discounted too heavily even if they are highlighted, a difficulty "inherent in play now, pay later" contracts. Highlighting them, however, would help minimize the over-discounting problem.

${ }^{106}$ See Administrative Procedure Act, 5 U.S.C. $\$ 553$ (1994) (setting forth the rulemaking requirements of general notice and an opportunity for interested persons to participate). 
The tobacco deal, in either of its two incarnations, would have failed our transparency requirements. It did not contain a liquidated damages provision nor did it expressly state that the government promised to pay damages in the event that Congress either outlawed nicotine prior to the year specified by the law as the earliest date for such action or lifted some of the obstacles to FDA regulation of tobacco that the bill contemplated would remain in place for twenty-five years. Nonetheless, under Winstar, if Congress had enacted some version of the tobacco deal, a court could have required the federal government to pay damages to the tobacco companies for repealing any part of the complex legislation prior to the date contemplated by the original deal, which for most purposes would have been twenty-five years from the date of enactment. Yet did anyone (other than the tobacco lawyers whom we presume are worth the money they are paid) understand that the people of the United States were being asked to assume the risk that this law was a huge mistake? Did anyone (again, other than the tobacco lawyers) understand that if the tobacco deal was passed and ended up failing to achieve any of its purposes, we might not be able to afford to repeal any material part of it because the damage payments that might be due to the industry (even discounted by the probability that the Court would carve a tobaccoexception to Winstar) would be more than we could afford to pay? Certainly no newspaper article that we have found discussed the contractual nature of the tobacco deal or mentioned the possibility of damage payments, and no member of Congress mentioned this during the debate on the McCain bill ${ }^{107}$ or at any other time, as far as we have been able to tell. We are convinced that as soon as the public and lawmakers focused on the possibility, however remote, that the tobacco bill might leave us paying the industry, instead of the other way around, this approach to the tobacco problem would have been dead.

Winstar invites opportunism, not by the government, but by private parties. Private parties are always more likely than the public to know whether the deal they are entering with the government (be it a deal memorialized in legislation or regulation) sounds enough in contract to support a plausible threat in the future that a change in policy will cost the government dearly. The public (and the legislature, at least when it comes to agency contracts) is much less likely, both during and after contract formation, to be aware that damages might be

${ }^{107}$ See supra notes 14-18 and accompanying text (discussing the McCain bill). 
due upon breach. Even where the possibility of breach is obvious, the public is also unlikely to have any idea how to assess the amount any such damages might be. The tobacco story we just told demonstrates the true dangers of living under a Winstar regime, and the pressing need for the Court to adopt transparency requirements that might help prevent a replay of last year's events, only this time with a scarier ending.

\section{PROTECTING SOVEREIGNTY THROUGH SUBSTANCE}

Assume that all the transparency requirements we advocated above are adopted. ${ }^{108}$ Why should Congress or a state or city legislature not be held to the contracts it makes? We return then to the problem with which we began: Imagine the year 2003. Neither Congress nor the President wants to raise taxes on the eve of a presidential election year. On the other hand, both the President and Congress want to spend money on programs popular with a majority of the American people: education, health care, infrastructure improvements, intelligence agency programs aimed at terrorism, or whatever else seems pressing that year.

Luckily, the merger-mania of previous years has produced mammoth conglomerates with serious cash to spend on the right investments. The senior management of Travelers or some other outsized company has, as most company management teams have, a laundry list of initiatives that would greatly benefit the company. Through lobbying and strategically placed campaign contributions (assuming no effective campaign finance reform has been enacted), some of these initiatives stand a better than even chance of becoming law; others do not. Those that get enacted will, in all likelihood, stay enacted for the foreseeable future, but there is always some risk that some unforeseen event will give next year's Congress (or some later Congress) a strong enough reason to change the law.

The CEO has an idea. Why not draft a bill with all (or almost all) of the desired government policies in it and offer to pay $\$ 10$ billion up front for such a law and $\$ 1$ billion every year thereafter for the next fifty years, the length of time the bill specifies it is to stay in effect as law? Our transparency requirements have been enacted, so the bill would have to state explicitly that it is a contract, that the federal government agrees to pay damages in the event of breach, and the sums

${ }^{103}$ An eventuality we consider highly unlikely but nonetheless probably more likely than the Court's adopting the proposal we are about to make. 
that would have to be paid as damages should one or another part of the law be repealed before 2053-sums that are in the billions of dollars. With the $\$ 10$ billion up front payment, Congress could fund some popular programs without raising taxes and the $\$ 1$ billion a year thereafter would undoubtedly also come in handy. To many lawmakers the legislative provisions of this bill appear desirable-or at least not too bad. They begin to tout the virtues of this bill, arguing that it makes sense today, and that it will make sense tomorrow. Who can prove otherwise? All crystal balls function equally well and are seldom, if ever, likely to reveal the same picture.

The law is passed. Why should a court not hold us to this bargain? What, if anything, is wrong with bargaining of this sort that it should not be treated with the respect to be accorded all (or at least, most) ${ }^{109}$ fully informed trades?

The short answer is that such a bargain undermines a fundamental norm, a norm that legitimates our government-majority rule. ${ }^{130}$ Regulatory contracts undermine majoritarianism in two separate ways: by entrenching the will of past legislatures and by transferring sovereign power to private parties. Only the strongest of normative justifications could, therefore, possibly sustain court enforcement of regulatory contracts. After examining possible justifications, we find none of them sufficient to warrant undermining majority rule.

\section{A. Majoritarianism and Constitutional Entrenchment}

Majoritarianism is a constitutional norm. We do not mean that the United States Constitution was intended to operate, or now operates (through the institution of judicial review or in any setting in which it is appealed to as evidence of what is right), primarily in the service of majoritarian goals. ${ }^{111}$ By "constitutional norm" we mean a

${ }^{109}$ Of course, some "ordinary" contracts are not accorded this respect. See, e.g., RESTATEMENT (SECOND) OF CONTRACTS $\$ 178$ (1979) (providing that certain terms of a contract may be unenforceable on grounds of public policy).

${ }^{110}$ At least one of us believes that an equally strong argument against these contracts may be made on grounds not fully developed here. See Susan P. Koniak, Whose Law Is It Anyway?, 9 YAIE J. ON REG. 575, 604-06 (1992) (concluding in a review of CORPORATE LAWBREAKTNG AND INTERACTIVE COMPLIANCE (Jay A. Sigler \& Joseph E. Murphy eds., 1991) that fairness and impartiality are higher legal values than flexibility and responsivity).

111 Some scholars seem to argue that the Constitution and the institution of judicial review properly understood are dedicated to enhancing popular sovereignty. See, e.g., 1 BRUCE ACKERMAN, WE THE PEOPLE: FOUNDATIONS 191-93 (1991) (characterizing judicial review as a mechanism to prevent factionalism); Akhil Reed Amar, The Bill of Rights as a Constitution, 100 YALE L.J. 1131, 1206-08 (1991) (hypothesizing that both 
norm so central to group definition (to that which constitutes a group) that to undermine the norm is to undermine the group. To the extent that group members come to believe that those who purport to control the group have abandoned their commitment to a constitutional norm, the legitimacy of the leadership is discredited, and the legitimacy of resistance to that leadership-in the name of preserving the norm and thus restoring the group's integrity-is bolstered.

As we use the term "constitutional norm," some of the norms in the Constitution are constitutional for almost all, if not all, Americans-for example, freedom of speech. That does not mean that all Americans agree on what threatens the norm and what does not. It means that all or almost all agree that the norm is at the essence of our national identity, and consequently, if most people came to believe that our government had stopped acting in accordance with that norm, we would be a nation in crisis. Other norms in the Constitution are constitutional for some groups in our society and not for others-the right to bear arms is an example. Our claim is that the norm of majority rule is as constitutional, in the sense we have just described, as free speech or any other norm in our national pantheon.

The existence of norms widely accepted as constitutional, like free speech and majority rule, makes us a nation. ${ }^{112}$ They facilitate norma-

Madison and Jefferson intended judicial review to encompass both jurors and judges); Akhil Reed Amar, Philadelphia Revisited: Amending the Constitution Outside Article V, $55 \mathrm{U}$. CFI. L. REV. 1043, 1055 (1988) (describing the people as both the masters and the source of the Constitution). Our argument is different. First, to the extent it makes sense to speak of the intent of the framers, we think that intent included a powerful desire to counter majority preferences. Second, as to judicial review, while we will argue that majoritarianism has an important role to play in defining the proper scope of that institution, we do not believe that the Supreme Court now (or ever) has acted, or should act, in the service of majoritarianism to the exclusion of all other competing norms.

${ }^{112}$ Consider for a moment the reaction of the country (and the existence of constitutional norms makes it possible to speak of that reaction as singular in some meaningful, although not precise, way, given that there will always be a subgroup following a prophet with some radically different understanding) if the government of Trenton, New Jersey were to assume dictatorial power. Whether or not there were open revolts in Trenton, this state of affairs would in all likelihood be seen as intolerable by Americans outside of Trenton. Indeed, the normative argument used to justify our tolerance of non-majoritarian governments elsewhere in the world always begins with "their" right to define themselves differently than we do, which itself can be seen as an expression of the norm of majoritarianism. On the other hand, the weakness of that claim is to be found in the growing tendency of Americans (and others) to define perpetual self-government or self-determination as a universal human right.

That phenomenon is not unusual. Constitutional norms, by definition, are so cherished by the groups whose norms they are that the "right" of others to reject them 
tive discourse across the many groups that make up the greater society-groups whose particular normative understandings and commitments are complex and often diverge from one another's. Because constitutional norms are scarce and enormously valuable commodities in the normative life of a nation, their meaning is bound to be hotly contested. ${ }^{113}$ While it may not be possible to speak of the meaning of a constitutional norm in a nation as big and diverse as ours, it may nonetheless be possible to speak of normative positions that most Americans would likely consider too strained to count as plausible interpretations of a norm. Just as knowledge of what is true is not a necessary condition for knowledge of what is false, agreement on what a norm means is not a necessary condition for agreement on what it does not mean.

Because majoritarianism is a powerful constitutional norm in this country, the argument that the Supreme Court should use its power to strike down laws only in the name of majoritarianism is forceful. ${ }^{114}$ On the other hand, we believe (although these things are not matters that lend themselves to easy proof) that there is a widely shared consensus in the nation that majoritarianism should yield at times to other compelling constitutional norms. There is even some substantial agreement on the norms that might qualify for that exalted posi-

is difficult to accept and the "choice" of others not to value them is difficult to conceive of as informed without assuming that those who make that choice are somehow not as worthy as we. Thus, tolerance as a constitutional norm is quite difficult to maintain, at least when it comes to any matter of critical normative importance, as this nation's experience and the experience of all groups demonstrates. For this reason, there is wisdom in prohibiting the establishment of religion as a means of protecting freedom of religion. By attempting to prevent a religious creed from becoming a constitutional norm, the First Amendment helps to maintain freedom of religion as a constitutional norm.

${ }^{113}$ "Were [a uniformity of meaning to occur] for a fleeting moment, a philosopher would surely emerge to challenge the illusion of its identity with truth. The unification of meaning ... exists only for an instant, and that instant is itself imaginary [yet enormously potent]." Robert M. Cover, The Supreme Court, 1982 Term-Foreword: Nomos and Narrative, 97 HARV. L. REV. 4, 15 (1983) (footnote omitted). Consider the powerful, imaginary, and fleeting nature of the moment in which Brown v. Board of Education was accepted by almost all Americans as right. See Louis Michael Seidman, Brown and Miranda, 80 CAL. L. REV. 673, 674-75 (1992) (describing how Broum was initially one of the most controversial decisions ever issued by the Court and how it has become "common ground" that Brown is correctly decided while at the same time admitting that "muted debate" about the correctness of the decision continues and, more importantly, offering in the remainder of his imaginative article, a strong critique of Brown).

114 That does not mean that we believe it is plausible to argue that the framers intended that result or that the Supreme Court has ever accepted such a limit on the power of judicial review. We do not so believe. 
tion: liberty and equality. ${ }^{115}$ The consensus that it is right for the powerful norm of majoritarianism to yield on occasion is manifested, however paradoxically, in the intensity of the struggle over what the Constitution means.

Constitutional interpretation is important precisely because it is understood as the single legitimate method of trumping the constitutional norm of majority rule. It is the background norm of majoritarianism and its power that elevates a debate over the meaning of a few pages of text into a discussion of fundamental values, of the right way to live and to relate to one another.

Just as the constitutional debate is infused with power and meaning by the background norm of majoritarianism, the norm of majoritarianism is reinforced and celebrated by its exception: constitutional command. The expressive power of law works just that way: an exception may proclaim its own importance and, at the same time, the importance of the rule. Thus, constitutional entrenchment, the triumph of an imagined consensus of the past over the manifest will of the present majority-or what is accepted as its proxy, the present legislature-cannot merely coexist with a powerful constitutional norm of majoritarianism, but may reinforce that norm. We believe that for the most part constitutional entrenchment has functioned just that way. The relative rarity of Supreme Court decisions invalidating laws and the extraordinary procedures that must be followed to entrench new concepts have served to reinforce the power of the background norm-the majority should rule.

By legislative entrenchment we mean a legal hierarchy in which the will of a past legislature trumps the will of a present legislature. ${ }^{116}$

${ }^{115}$ Again, that does not mean there is consensus on what these norms mean although we believe that across a substantial area of normative space there is a widely shared sense of what these norms do not mean. For example, we believe that very few groups or individuals in present day America would maintain that adult sex with children or sexual activity by anyone with animals is within the concept of liberty. Our reference to a substantial area of normative space simply means that there are many other examples like this one.

${ }^{116}$ Our concern is not limited to legislatures. The argument we make applies whether it is a present legislature attempting to bind a future legislature or a present executive branch official or administrative agency trying to bind a future legislature, executive officer, or administrative agency. Notice that we did not include in the list a present legislature binding a future executive branch official or administrative agency. That situation is different because in our system, the formal hierarchy of law provides generally that neither an act of the executive nor one of an administrative agency may trump a legislative decision. As long as in the future, the majority, through some arm of government, can express its will without encountering some extra-constitutional legal impediment put in place by a past majority acting through an equal or lesser arm 
Of course, it is true that in some sense all acts of present legislaturefor example, decisions about whether to declare war, how much money to print, whether to invest in infrastructure, and whether to invest in education-limit what future legislatures might do. By creating so-called entitlement programs such as Social Security, Medicare, and Medicaid, past legislatures created present expectations that succeeding legislatures have found all but impossible to ignore. ${ }^{117}$ In all such examples, however, the future legislature is limited either because past acts have changed the physical world or because they have changed how people perceive the world, their place in it, and the duties of their government in a way that creates a future consensus for one policy or another. As to the second phenomenon (past legislation shaping perceptions), it is not properly seen as legislative entrenchment in that it is the present majority whose will stands in the way of changing what a past legislature has done. ${ }^{118}$ Moreover, neither phenomenon (physical world entrenchment nor perception entrenchment) can be eliminated. Majority rule would be meaningless without the ability to decide matters that have future consequences on the physical world or mental perceptions, and, in any case, no limit on

of government, there is no problem of entrenchment, as we mean to use the term.

Notice too that one might plausibly argue that the hierarchy of legal authority on its own prohibits a past administrative agency (or executive branch official) from binding a future legislature. The Supreme Court sidesteps this problem with its broad delegation doctrine, which allows it to treat a regulatory contract made by a past administrative agency (or executive branch official) as if it were a regulatory contract made by a past legislature on the ground that a past legislature delegated to the past agency or official the power to make contracts. See, e.g., United States v. Winstar Corp., 518 U.S. 839, 890-91 (citing the statutory history that authorized FSLIC and the Bank Board to make contracts governing the treatment of regulatory capital). For that reason and for ease of reference, we will use the term "legislative entrenchment" to refer to entrenchment by past administrative agencies and executive branch actors as well as by legislatures.

${ }^{13}$ But see Personal Responsibility and Work Opportunity Reconciliation Act of 1996, Pub. L. No. 104-193, 110 Stat. 2105 (codified in scattered sections of 42 U.S.C.) (limiting social welfare benefits).

${ }^{118}$ This phenomenon points to an important distinction between retroactive legislation and regulatory contracts. Louis Kaplow was right in noticing that regulatory contracts involve many of the same problems raised by retroactive laws. See Kaplow, supra note 3, at 563-64 (stating that both retroactive laws and regulatory contracts present concerns about retroactive effects and the ability of government to later modify any provisions made). Indeed, see infra note 191 and accompanying text, where we rely on his insights to support our proposal. As his main concern was neither regulatory contracts nor the preservation of the majoritarian process, however, he did not concentrate on the fact that regulatory contracts (unlike the other methods that he discusses of relieving people of the consequences of legal transitions) are made ex ante (by a past legislature), and thus, before the need for a legal change has become apparent. 
majority rule could prevent either phenomenon. ${ }^{119}$ For those reasons, we do not consider either phenomenon as an example of legislative entrenchment.

On the other hand, the fact that present decision making necessarily affects future decision making, in the ways we have just discussed, does not mean that the present majority should be free to add to the natural effects of its decisions additional impediments to having its will overturned by a future majority. By "additional impediments" we mean provisions of law that prohibit or otherwise restrict the right of a future legislature to repeal a law. Those impediments are what we mean by entrenching mechanisms, and they may take various forms.

The leading commentator on legislative entrenchment, Julian Eule, identified four varieties: absolute entrenchment, which denies the power to repeal for all time; procedural entrenchment, which demands that extraordinary procedures be followed to effectuate a change; transitory entrenchment, which denies the power to repeal for a specified period of time; and preconditional entrenchment, which allows change "only on the occurrence of a preordained event. ${ }^{120}$ The Constitution, as Eule pointed out, uses all but the first of his entrenchment devices $^{12 l}$ without directly addressing Congress's power to bind its successors through the use of similar devices or the power of state legisla-

119 One could try to identify those legislative actions whose power to alter the future seem unalterable or so severe that one legislature should not be permitted to take them at all or at least not without following extraordinary procedures. The problem with this exercise is that not acting also has long-term and severe consequences. Thus, it seems to us incoherent to limit majority rule based on the degree to which a majority's decision might affect the physical world or the mental perceptions of persons within a society.

${ }_{120}$ Julian N. Eule, Temporal Limits on the Legislative Mandate: Entrenchment and Retroactivity, 1987 AM. B. FOUND. RES. J. 379, 384-85. Eule noted that absolute entrenchment is rarely used. See id. at 384 ("Rarely is an attempt at entrenchment seen in such unqualified form.").

${ }_{121}$ See id. at 385 (arguing that Article $\mathrm{V}$ of the Constitution uses the three entrenching devices short of absolute entrenchment). Article V specifies that two clauses of Article I (on the importation of slaves and the proportionality of direct taxation) shall not be changed until 1808, which "exemplifies transitory entrenchment." Id. (emphasis added). Article $\mathrm{V}$ also prohibits "deprivation of a state's equal suffrage in the Senate absent the consent of that state," which is an example of preconditional entrenchment, i.e., no change in the rule unless a particular event occurs. Id. Finally, as to the rest of the Constitution, Article V requires "extraordinary procedures for alteration," which is an example of procedural entrenchment. Id. We recognize that the "state consent" requirement could be described as procedural entrenchment instead of preconditional entrenchment, but preconditional entrenchment need not be procedural at all. A regulatory contract, for example, could provide that it was to last for 10 years but that the government had a unilateral right to cancel at any time if war broke out in the Middle East. 
tures to entrench their will against the will of their successors. One could argue that the extraordinary process detailed in the Constitution for amending the text, that is, for entrenching new policies, is inconsistent with entrenchment of any sort by ordinary legislative act, but Eule rejects that argument as too simplistic. ${ }^{122}$ For him, the framers' pro-entrenchment bias, evident from their willingness to entrench their own views of the public good, acts as a counterweight to whatever anti-entrenchment bias might be implied from the extraordinary procedures for amending the Constitution outlined in Article V. ${ }^{123}$ In other words, for Eule, the very existence of constitutional entrenchment implies that legislative entrenchment may also be constitutional. Eule thus embarks on a search for more specific constitutional text to bolster his intuition that entrenching devices should be given no effect by the courts, which is precisely what extant cases that specifically address this question hold, albeit without specifying that the Constitution dictates this result.

Eule argues that all four methods he identifies as entrenching violate specific provisions of the United States Constitution and state constitutions. ${ }^{124}$ His argument is this: in England, each Parliament is

${ }^{122}$ See id. at 399 ("Admittedly, [Article V] must be interpreted as providing the exclusive vehicle for amendment, but it does not follow that any enactment that has some entrenching impact on future legislatures must necessarily be regarded as an amendment").

${ }^{123}$ Eule suggests that accepting constitutional entrenchment as a good somehow requires one to concede that legislative entrenchment might be similarly justified:

James Madison, albeit a man of vision, was no oracle. Do not the utilitarian fears counsel against the petrification of a constitutional structure to the same degree that they warn against the entrenchment of a legislative command? Were the Framers blessed with greater powers of progn[o]stication or purity of motive than are possessed by those the people elect to govern them?

Id. at 389 (footnote omitted). Eule makes clear that he accepts the good of constitutional entrenchment, although he leaves a full-blown defense of that argument for another day. See id. at $385 \mathrm{n} .19$ (deferring discussion of the validity of the assumptions underlying constitutional entrenchment to a future date). Nonetheless, he makes clear in this work the underlying premise of that argument: the Constitution is an expression of the sovereign, the people, while legislative acts are an expression, not of the sovereign, but of the agents of the sovereign. His argument against legislative entrenchment thus hangs on the temporal limits of the agency conferred on legislatures by the sovereign people. While we think this is a neat argument, to the degree it suggests that the institution of judicial review is somehow more majoritarian than the acts of elected representatives, we do not buy it.

${ }^{124}$ Eule makes his main argument while considering only federal legislative entrenchment, concluding that Article $\mathrm{I}, \S 2, \mathrm{cl} .1$, and $\S 3, \mathrm{cl}$. 1, set out the term lengths of members of Congress. "Just as the members of Congress lack power to extend their terms beyond those set by the Constitution, they may not undermine the spirit of that document by immutably extending their influence beyond those terms." Id. at 404 . 
sovereign, i.e., the supreme source of law during its existence; therefore, its laws cannot be trumped by laws emanating from any other source, including past Parliaments. ${ }^{125}$ Congress, on the other hand, is not sovereign. In the United States, the people are sovereign, and their will is expressed in both the Constitution and through periodic elections. The Constitution, recognizing the importance of frequent elections to the people's retention of sovereignty, limits the terms of legislators. The "spirit" of those constitutional limits is undermined when legislators seek to extend their influence beyond those terms through entrenching devices, just as surely as the letter of those constitutional provisions would be violated by legislation purporting to extend the actual length of the terms that Senators or House Members serve. Eule thus concludes: "Ironically, therefore, the entrenchment prohibition, which in England originates in the perpetual nature of legislative power, emanates in the United States from the transitory nature of such power. ${ }^{\text {"126 }}$

We think Eule's constitutional analysis is plausible, assuming one accepts his premise that the existence of constitutional entrenchment suggests that legislative entrenchment is equally acceptable. ${ }^{127}$ We reject, however, the idea that absent specific constitutional text, no principled basis exists on which to prefer a later legislative act over an earlier act with which the later act is inconsistent. Majoritarianism dictates the preference. If majority rule means anything, it means rule by the current majority and not by a majority of the past. That is the point of elections. Moreover, our understanding of the relationship between constitutional entrenchment and majority rule differs strongly from Eule's. We see constitutional entrenchment as reinforcing, however paradoxically, the background norm of majoritarianism; he sees it as placing the virtue of rule by the present majority in doubt.

Eule refuses to rest his rejection of legislative entrenchment on

Later, while discussing the Contracts Clause, which is directed exclusively to the states, Eule suggests in a footnote that both the clause guaranteeing states a republican form of government and state constitutional provisions setting the terms of state legislators yield the same result for the states. See id. at $420 \mathrm{n} .189$ (deriving from state constitutions and the provisions of Article IV, Section 4 of the Constitution a basis for application of his thesis to both state and federal bodies).

${ }^{125}$ See id. at 391-93 (discussing the volitional abolishment of entrenchment by Parliament itself).

${ }_{126}^{12}$ Id. at 403-04.

127 It is that premise, which we reject, that sends Eule searching for constitutional text to support the proposition that later legislative acts should trump earlier ones. Our understanding of the constitutional importance of majoritarianism dispenses with the need to support an absolute preference for later legislative acts (over earlier ones) with constitutional text. 
majoritarianism not only because he understands constitutional entrenchment as undercutting that norm but also because he is apparently embarrassed by how far from majoritarian American political life really is. ${ }^{128}$ Although Eule does not specify which aspects of American political life embarrass him, we can easily imagine what he might have in mind. The small number of Americans who actually vote and the disproportionate influence of wealthy corporations and individuals are two obvious examples. We too are embarrassed by those facts, but we contend that our embarrassment and Eule's come from the same place-the power of the majoritarian norm. Indeed, we would claim that most Americans, if asked, would be just as embarrassed by these facts. Thus, those who argue against campaign finance reform must stand on a constitutional norm that has some chance of trumping majoritarianism-free speech-to make their argument tenable and avoid similar embarrassment.

Despite Eule's claims that it is the text of the Constitution that convinces him that the Court should not uphold entrenching devices, this constitutional interpretation derives not only from his own commitment to the norm of majoritarianism but also his belief that it is an enormously powerful constitutional norm (agreeing with us). $\mathrm{He}$ concludes his argument on the reading of the text of the Constitution in this way:

\begin{abstract}
Each election furnishes the electorate with an opportunity to provide new direction for its representatives. This process would be reduced to an exercise in futility were the newly elected representatives bound by the policy choice of a prior generation of voters. The fundamental, albeit admittedly often suspect, assumption of American political life-that legislative action reflects current majoritarian preferences - could be finally laid to rest if shifting majorities were unable to alter prior majoritarian choices. It is unfortunate that legislative inertia and retentionist biases often prevent the repeal of anachronistic statutes that could not be presently reenacted and thus can be said to lack current majoritarian support. It would be intolerable, however, if additional obstacles set in place by the enacting legislatures had to be hurdled for the new majority to find a statutory voice.
\end{abstract}

We could not have said it better.

Before moving on to consider the extent to which regulatory contracts resemble other entrenchment devices, we wish to examine how the Court in Winstar treats the relationship between constitutional and

${ }^{128}$ See id. at 405 (noting the persistence of anachronistic statutes, that despite their lack of majoritarian support, Congress has not repealed).

${ }^{129} I d$. at 404-05 (footnote omitted). 
legislative entrenchment. Justice Souter, writing for the plurality, cites Eule's article as the source of his perspective on the two forms of entrenchment:

In England, of course, Parliament was historically supreme in the sense that no "higher law" limited the scope of legislative action or provided mechanisms for placing legally enforceable limits upon it in specific instances; the power of American legislative bodies, by contrast, is subject to the overriding dictates of the Constitution and the obligations that it authorizes.

In short, Souter agrees with Eule that the Constitution somehow places the question of whether current legislation should trump past legislation in doubt.

According to Souter, the current legislature's power is limited not only by the "dictates of the Constitution" but also by "the obligations that [the Constitution] authorizes." last phrase emerges when one contrasts it with an alternative, "the obligations that the Constitution demands be honored." This alternative leads to the Contracts Clause, which has been read since Chief Justice Marshall's time to prohibit the states from impairing the obligations of (some) contracts made by predecessor state governments. ${ }^{132}$ Souter's language, on the other hand, points to no specific constitutional text. Rather, it suggests that the Constitution in some unspecified manner requires that Congress honor certain "obligations" that the text has empowered it to undertake (and perhaps also those that it does not prohibit a state from undertaking, which might also be considered "authorized").

Where in the Constitution is that principle to be found? Souter never tells us. He might have argued that the Due Process Clause of the Fifth Amendment prevents the federal government from interfering with its own contracts, thereby reviving the spirit of Lochner ${ }^{133}$ albeit with a twist: public contracts would be treated as creating rights with which the government could not interfere, while private contracts would presumably continue to be treated as if they created no such rights. But Souter does not cite the Due Process Clause or any other provision of the Constitution as the source of this limit on Con-

${ }^{130}$ United States v. Winstar Corp., 518 U.S. 839, 872 (1996) (plurality opinion).

131 Id.

192 See Fletcher v. Peck, 10 U.S. (6 Cranch) 87 (1810) (declaring that a legislature cannot void its past contracts, including grants of land, by passing new legislation).

${ }^{133}$ Lochner v. New York, 198 U.S. 45 (1905). 
gress's power (and perhaps also on state legislatures' power), ${ }^{134}$ although a later Supreme Court case does briefly refer to Souter's opinion as if it were grounded in the Due Process Clause. ${ }^{135}$ Souter does, however, quote Chief Justice Marshall's opinion in Fletcher v. Peck, ${ }^{136}$ where Marshall identified two principles that prevented the thenpresent Georgia legislature from reneging on its own contract: the Contracts Clause (which of course would be inapplicable in the federal law context of Winstar), and an inherent limit on "legislative power" resulting largely from natural law as opposed to the Constitution's text. Given Souter's understanding that Parliament's legislative power includes no such inherent limit, one would expect him to justify his insistence on imposing this limit on Congress's legislative power in the absence of specific constitutional text. This is an obligation he assuredly does not fulfill.

\section{B. Regulatory Contracts as Legislative Entrenchment}

Regulatory contracts do not fit neatly into Eule's entrenchment categories. ${ }^{137}$ Under current Supreme Court doctrine, which denies specific enforcement as a remedy for government breach, ${ }^{138}$ regulatory contracts do not involve transitory entrenchment, as Eule uses that term, in that a succeeding legislature may change the law before the contract's expiration date as long as damages are paid. Regulatory contracts also do not involve preconditional entrenchment, as Eule intended to use that term. Instead of conditioning repeal on the occurrence of some prior event (precondition), regulatory contracts impose a financial cost (a tax or a fine, if you will) on the exercise of the power to repeal. It is no accident that regulatory contracts fall outside Eule's categories. Eule sees regulatory contracts as attempts at

${ }^{134}$ It is possible that this amorphous duty to honor "obligations" would extend beyond what the law might recognize as contractual duty. After all, the normal understanding of the word "obligations" encompasses more than responsibilities created by the exchange of mutual consideration necessary to the formation of a binding contract.

See Lynce v. Mathus, 519 U.S. 433, 440 (1997) (citing Winstar to support the proposition that "the Constitution places limits on the sovereign's ability to use its lawmaking power to modify bargains it has made with its subjects").

10 U.S. (6 Cranch) 87 (1810).

137 See Eule, supra note 120, at 384-85 (defining forms of entrenchment as absolute, procedural, transitory, or preconditional).

${ }^{133}$ Of course, specific performance is not normally available for breach of contract even when both contracting parties are private parties. See RESTATEMENT (SECOND) OF CONTRACTS $\$ 359(1)$ (1981) (stating that specific performance is not to be ordered if damages would be adequate remedy). 
entrenchment only insofar as specific enforcement is the remedy for breach, which would place them squarely in his transitory entrenchment category.

Here, Eule and the majority of the Justices in Winstar seem to agree: neither considers a tax imposed by a former legislature on a specific policy choice of a current legislature to be entrenchment. We do. ${ }^{139}$ Indeed, we see the point as so obvious that we are at a loss as to what more there is to say. We thus turn to the arguments advanced by Eule and Souter to sustain the opposite conclusion. Unfortunately, Eule substitutes assertion for argument. At first, he seems to be on our side: "This entrenching of legislative error may seem fair under someone's theory of equitable estoppel, but it slights the temporal limits of legislative authority and handcuffs the ability of the current representatives to serve the legitimate needs and desires of their constituents. ${ }^{\text {,140 }}$ Ultimately, he excludes damages-only contracts from entrenchment. He fails to explain, however, the basis for distinguishing preconditional entrenchment, which he views as unconstitutional, from postconditional entrenchment, which he would allow. ${ }^{141}$

Souter also fails to distinguish a requirement to pay damages from illegitimate forms of entrenchment. He states that:

[W] hile agreements to insure private parties against the costs of subsequent regulatory change do not directly impede the exercise of sovereign power, they may indirectly deter needed governmental regulation by raising its costs. But all regulations have their costs, and Congress itself expressed a willingness to bear the costs at issue here....

${ }^{139}$ The recognition that regulatory contracts may deter regulatory change is Gillian Hadfield's starting point in a thoughtful examination of what type of contract remedies would be most normatively defensible in Winstaxtype litigation. See generally Gillian Hadfield, Of Sovereignty and Contract: Damages for Breach of Contract by Government, 8 S. CAL. INTERDISC. L.J. 467 (1999) (assessing the justifications for expectation damages in breach-of-contract cases and concluding that reliance damages are a more normatively appealing measure).

${ }_{140}$ Eule, supra note 120, at 423.

141 Eule may have carved out damages-only contracts from his list of entrenchment devices that the courts should ignore at least in part because he believed that the Supreme Court, having treated government contracts as subject to the Contracts Clause for virtually all of constitutional history, would never seriously reconsider that position. See id. (calling the argument that the Contracts Clause does not apply to government contracts as "tilting at windmills").

${ }_{142}$ United States v. Winstar Corp., 518 U.S. 839, 883 (1996) (plurality opinion). Justice Souter's plurality opinion repeatedly refers to the alleged arrangement between federal bank regulators and the thrifts as an insurance contract, as if to suggest that the contract functions the same as, and is no more problematic than, the conventional insurance contracts with which we are all familiar. See id. at 894 (comparing the gov- 
That is true, but the fact that all regulatory change entails some costs does not mean that the threat of regulatory contract damages will not slow or even stop change that otherwise might have occurred. Here, the well-developed debate regarding the Takings Clause is instructive. Both advocates and opponents of broad applications of the Takings Clause agree that requiring the government to pay for regulatory change would result in less regulatory change. They simply disagree as to whether that would be a good thing. ${ }^{145}$

There is good reason to think (and for legislators and agency officials to believe) that regulatory contract damages often would be substantial and thus would serve as a powerful deterrent to later legislative change. Private parties to enforceable regulatory contracts have no incentive to minimize the costs to themselves of possible regulatory change; quite the contrary, precisely because they may wish to stop such change and, in any event, because they hold a legal entitlement to damages resulting from such change, ${ }^{144}$ such parties might take actions to enhance the government's damages liability. This point-that the private parties to regulatory contracts can control, to some extent,

ernment to a private insurer through its regulation of capital reserves). The alleged arrangement between the regulators and bank board, however, differs from conventional insurance contracts in one critical respect: the risk that is ostensibly being insured against (that is, the risk of regulatory change) is under the control of the insurer. In conventional insurance, the insurer insures against a risk external to itself and hence beyond its control (for example, an earthquake or a theft in a homeowner's policy). Thus, in the regulatory contract setting as opposed to the conventional insurance setting, the existence of the contract predictably will result in reductions in the likelihood of the insured-against risk.

143 See, e.g., Richard A. POSNER, ECONOMIC ANALYSIS OF LAW 56-61 (4th ed. 1992) (favoring compensation requirements on the ground that legislatures will impose more regulations if doing so does not require compensation for the private costs of the new regulations); Michael C. Blumm, The End of Environmental Law? Libertarian Propenty, Natural Law, and the Just Compensation Clause in the Federal Circuit, 25 ENVTL. L. 171, 179-80 (1995) (criticizing an expansive interpretation of the Takings Clause on the grounds that "increased compensation requirements will produce less regulation, which in turn will produce more environmental injuries"); J. Peter Byrne, Ten Arguments for the Abolition of the Regulatory Takings Doctrine, 22 ECOLOGY L.Q. 89, 131-36 (1995) (arguing that expansive interpretations of the Takings Clause will result in insufficient regulation to protect against long-term environmental risks); Michael $M$. Berger, Environmental Protection? It Depends on Who is Paying, L.A. DAIIYJ., Aug. 1, 1993, at 7 (predicting - and praising - the reduction in regulatory burdens on private landowners that would result from compensation requirements). For a dissenting view from the general consensus that more compensation requirements means less regulation, see Glynn S. Lunney, Jr., A Critical Reexamination of the Takings Jurisprudence, 90 MICH. L. REV. 1892, 1958-59 (1992) (arguing that compensation may reduce opposition to regulation).

${ }^{144}$ For a discussion on reasons a private party might not see damages as the equivalent of performance, see supra text following note 26. 
the costliness of those contracts to the government-leads us to our second normative criticism of such contracts.

\section{Regulatory Contracts as Sales of Sovereignty}

Our argument thus far has been that regulatory contracts, like all entrenching devices, threaten majoritarianism by transferring sovereignty to past majorities and their representatives. Yet regulatory contracts pose an additional threat to majoritarianism not found in any other form of entrenchment: they transfer sovereignty not just to the former sovereign, but to private parties as well.

The private party who holds a regulatory contract has the power ex post to release the sovereign from its promise by not seeking damages, to reduce the sovereign's cost of a particular decision by claiming or actually incurring fewer damages, or to make the sovereign's decision more burdensome to make by acting to increase the damages that would be due upon breach.

It is at least as inconsistent with majoritarianism to transfer power to private hands (by definition, also a minority) as it is for a present majority to extend its power into the future. The principle that majority power may not be transferred into private hands is reflected in that part of the nondelegation doctrine that still stands-that the government may not delegate legislative power to private groups. ${ }^{145}$

But is the power to contract not itself a power of sovereignty? That might at least distinguish the nondelegation cases, where government power was transferred as a gift as opposed to an exchange for consideration. Perhaps a majoritarian conception of democracy is inconsistent with gifts, but not with sales for value. In Perry $v$. United States, ${ }^{146}$ the Court said that "the right to make binding obligations is a competence attaching to sovereignty." Can that be doubted?

We believe the answer is yes. Indeed, it is our position that the sovereign's power to enter into binding contracts is by the very nature of sovereignty ephemeral. How binding is anyone's promise to punish

145 See A.L.A. Schechter Poultry Corp. v. United States, 295 U.S. 495, 539-42 (1935) (striking down a delegation of legislative power conferred upon private parties to promulgate rules which apply a fair competition standard to virtually all of American industry); Susan Rose-Ackerman, Consensus Versus Incentives: A Skeptical Look at Regulatory Negotiation, 43 DUKE L.J. 1206, 1216-17 (1992) (discussing the constitutional limits on delegating government power to private groups, the seminal case on this point being Schechter, and noting that "American democracy traditionally is wary of delegating policymaking tasks to private groups").

294 U.S. 330,353 (1935). 
herself in the event that she does $x$ ? In other words, sovereignty necessarily includes (at least in any government structure we can imagine) control over the apparatus established by the State to enforce promises. This is true even in our system which divides sovereignty among various branches and levels of government precisely to avoid the awesome nature of concentrated sovereign power. As Justice Brandeis noted in Lynch $v$. United States, ${ }^{147}$ while the Court may hold that Congress is bound to honor a particular promise, Congress may always avoid that ruling, if not by open defiance of the Court, then by withdrawing from it jurisdiction to decide whether any or some subset of government promises are binding. Indeed, Congress or any other nation-state ${ }^{148}$ could simply print more money when held liable for contract damages. ${ }^{149}$ What would a court do then? For these reasons alone, we reject the idea that the power to enter into binding contracts is an incident of sovereignty in our country or anywhere else. ${ }^{150}$

147292 U.S. 571,585 (1934).

148 The European Union may impede member nations from printing money at will. See generally Brian K. Kurzmann, Challenges to Monetary Unification in the European Union: Sovereignty Reigning Supreme?, 23 DENV. J. INT'L L. \& POL'Y 135, $149-52$ (1994) (discussing legal challenges focused on upholding national monetary sovereignty).

${ }^{149}$ Even the plurality in Winstar conceded as much in the discussion of taxes. See United States v. Winstar Corp., 518 U.S. 839, 881 (1996) (plurality opinion) (“[A] requirement to pay [damages] supposes no surrender of sovereign power by a sovereign with the power to contract.").

${ }^{150}$ Here our argument appears to run counter to international law. Consider, for example, the following description of how international law treats the link between sovereignty and the power to contract:

The state as a sovereign entity possesses the power to grant rights and bind itself to agreed [upon] terms. To permit a state to use its sovereignty to disregard commitments that it freely undertook through the exercise of that very sovereignty would be anomalous. Such a result would undermine and destroy the legal framework of the international order.

Robert B. von Mehren \& P. Nicholas Kourides, International Arbitrations Between States and Foreign Private Parties: The Libyan Nationalization Cases, 75 AM. J. INT'L L. 476, 518 (1981). Despite the absolute terms of this quote, however, international law does recognize that there are certain powers (rights of governments) that may not be bargained away, generally referred to as "jus cogens," which literally translated means "compelling law." Id. at 521. That exception appears to mirror our Court's essential attributes to the sovereignty doctrine. See Winstar, 518 U.S. at 888 (defining the reserved powers doctrine as holding that "a state government may not contract away "an essential attribute of its sovereignty"). More importantly, however, whatever the "letter" of international law purports to dictate, the very nature of international law, such that nations submit to it on a "voluntary" basis and employ that submission as a means of establishing a reputation for trustworthiness, actually demonstrates the point we make in the text instead of contradicting it. Indeed, the authors of the vehement language quoted above conclude their article with the following reflections:

Arbitrations between private foreign investors and governments [to resolve al- 
Our claim is that the power to change the law, unlike the power to contract, is critical to sovereignty in our political system and should not be transferred to private entities. We have already suggested one way in which regulatory contracts transfer law-making authority to private groups by giving them the ability to control how much a change in law will cost. That is not, however, the whole picture. Regulatory contracts also make the private contracting parties to those contracts co-equal partners with the government in the creation, interpretation, and maintenance of public law. The legal regime promised in the contract may be created by the contract itself, which means that the private contracting party's acquiescence determines the law's content. Or, if the contract merely promises to maintain in place for $x$ years an extant regulatory regime, then the private contracting party's acquiescence determines the law's duration. In addition to providing the private contracting party with privileged control over the content and duration of public norms, regulatory contracts also afford the private contracting party control, not accorded other citizens, over the interpretation of the law embodied in the contract. Does a particular act violate the law of the contract? The practical significance of the legal regime specified in the contract can only be determined by considering what the private party (and the government) intended when the contract was formed. The private contracting party's understanding of the reach of a law or regulation will thus be privileged above that of other citizens. ${ }^{151}$

leged contractual breaches by those governments] are not common events. When disputes arise between them, they usually work out an arrangement or reach an agreement in order to preserve the beneficial relationship. In instances where the government expropriates or confiscates them foreign investor's assets ..., the investor ... has generally attempted to negotiate a settlement, ... rather than pursue legal proceedings against the government. Such proceedings can be laborious and time-consuming, and, even when successful, may prove in the end to be hollow victories because of the difficulty of enforcing the judgments and awards that result (although ... refusals [by governments] to comply [with awards] are rare).

Von Mehren \& Kourides, supra at 549. We wish to thank Detlev Vagts for leading us to this material.

${ }^{151}$ Taking public law private by making it the subject of a regulatory contract has important implications for the legitimacy of our legal system. Small, cohesive, voluntary groups (families, community groups, congregations of worshipers in a common faith) create and maintain law by agreement-by discussing together what they stand for and what actions are licensed and condemned by their shared principles. Robert Cover called this method of creating and maintaining law "paideic." Cover, supra note 113 , at 12-13. In the paideic world, law is legitimate precisely because it is personal: law is not forced upon adherents, nor enforced against them; it is their law because they embrace it, because they personally accept it. "Moreover, just as the law-receiver's acceptance and understanding of the law is personal in the paideic world, the law's 
Our consideration of majoritarianism thus leads us to this conclusion: Regulatory contracts are inconsistent with the norm of majoritarianism, the ideal of popular sovereignty, because they allow the past to tax the particular policy choices of the present majority and because they transfer majority power into minority hands. Enforcement of such contracts by the least majoritarian branch of our government, the judiciary, cannot be justified by arguing that judicial interference with the will of the present majority in the name of the contract somehow furthers majoritarian goals. ${ }^{152}$

We began, however, by conceding that constitutional entrenchment assumes that there are constitutional norms that are capable of trumping majoritarianism. In other words, perhaps there are powerful normative justifications for a transition policy that assures people ex ante that the government will compensate those adversely affected by a change in government policy, or at least those to whom the government has made such an explicit promise. Certainly, broad substantive protection for sovereignty might be wrong if there are strong

acceptance and understanding of the individual is also personal." Koniak, supra note 110 , at 593. In contrast to the paideic mode is the manner in which all levels of government in our nation create and maintain law-the imperial mode. When people are not brothers, when interpersonal commitments are weak and normative and cultural diversity abounds, law is enforced, not embraced. It is legitimate precisely because it is impersonal, objective, impartial, and fair.

Regulatory contracts build state law on personal acceptance and leave its contours to be determined on the basis of personal understanding and the intent of the contracting parties. Personalizing the law of the state undermines both the state and its law by suggesting that favoritism has replaced the imperial virtues of fairness and impartiality. There are paideic features in our legal system: the jury's power to nullify law, the pardon power, prosecutorial discretion, and judicial control over sentencing. Notice, however, that each of these institutions has been tamed, constrained, and limited by imperial devices. We not only prohibit instructing juries on their power to nullify the law, we painstakingly instruct them on the details of the "objective" norms they are to apply. Executives issue pardoning standards to govern how they exercise their power. Prosecutorial discretion is also checked by self-imposed guidelines and by statutory provisions like those in the Equal Access to Justice Act and ultimately (if not robustly) by the constitutional guarantees of due process and equal protection of the laws. Judicial discretion in sentencing is reined in by sentencing guidelines and statutory requirements. There is good reason for this tendency to make the paideic aspects of public law more imperial. Law maintained in imperial mode is law that knows no favorites. To move away from that notion toward a world of public law by private contract is to risk undermining the legitimacy of the legal and political order in our diverse society.

${ }^{152}$ It thus seems that those who argue that the institution of judicial review is justified only in the name of majoritarian principle should reject the enforcement of any regulatory contract. But see Michael J. Klarman, Antifidelity, 70 S. CAL. L. REv. 381, 383, 412 (1997) (supporting majoritarian judicial review as well as a strong interpretation of the Contract Clause). 
normative reasons to support the enforcement of regulatory contracts, and even the procedural protections that we advocate may go too far depending on the content of the normative objection.

\section{NO TRUMP}

\section{A. Is Judicial Enforcement of Regulatory Contracts Justified To Prevent Unfair Surprise and Opportunistic Singling Out?}

As both Michael Graetz and Louis Kaplow have explained in considering the question of compensating those harmed by the adoption of new legal rules, the argument that fairness requires compensating those who have relied on the old rule is circular. ${ }^{153}$ As Graetz put it: "[T] he argument asserts that people have a right to protection merely because either they now expect such protection or they expected such protection when they entered into a transaction; their expectations allegedly create a right and their asserted rights legitimate their expectations. $^{\text {154 }}$ He was not, however, speaking of expectations created by contracts. ${ }^{155}$ One might argue that a party with a regulatory contract is in a fundamentally different position: such a party's expectation is created by the contract, the government's promise, not "merely" its own optimistic view that the government, which often (or sometimes) in the past has provided compensation when it changes the law, will do so in the future.

That difference, however, turns out to be illusory. The reason that a private party's expectations created by a favorable contract might be said to differ from the expectations created by the mere existence of a favorable non-contractual law is that under our current regime, private contracting parties have a right to damages upon breach but not upon repeal of the law. ${ }^{156}$ If private parties entering into regu-

${ }^{153}$ See Graetz, supra note 3, at 78 (stating that because of the uncertainty inherent in the legislative process, "[i]ndividual reliance on the status quo simply will not suffice as a basis for compensation"); Kaplow, supra note 3, at 606 (claiming that arguments for compensation "are quite uncertain, cut in different directions, and are likely to be highly contingent on the circumstances").

${ }_{154}$ Michael J. Graetz, Retroactivity Revisited, 98 HARV. L. REV. 1820, 1823 (1985).

155 Kaplow, unlike Graetz, intended to include what we call regulatory contracts in his analysis of legal transitions, see Kaplow, supra note 3, at 563-64 (explaining how the Takings Clause and Contract Clause are related to transition policy), and thus presumably within his general rejection of fairness as a justification for compensating those harmed by legal transitions. He did not, however, specifically address whether contracts demand a different analysis.

${ }^{156}$ Of course, the government's so-called promise not to take away the mortgage 
latory contracts had no legal right to damages upon breach, their expectations would be based on their belief that political forces would operate to prevent the government from changing its policy. Of course, private parties holding explicit contractual government promises could argue that "you gave us your word," which could not be said by those merely disappointed by the government's failure to do as it had done in the past. ${ }^{157}$ They thus might estimate, quite accurately, a high probability that the government would honor its commitments to them. Before entering into the contract, however, they presumably would understand that the government's willingness to honor its commitments depends on a variety of factors following contract formation and thus incorporates some degree of uncertainty.

What of those who miscalculate either because they fail to understand that regulatory contracts are unenforceable in court or because they underestimate the risk that the government will break its promise? The Supreme Court has consistently held that individuals who rely on the word of government agents regarding what is lawful do so at their own risk. ${ }^{158}$ The Court has refused to bind the government to interpretations of law or regulations offered outside of formal proceedings, notwithstanding how reasonable it might seem to an ordinary American to assume that an IRS official, for example, could be trusted as speaking for the government. ${ }^{159}$ While both the unsophisticated and the sophisticated individual are likely to rely on the advice of government agents and thus are subject to the rely-at-your-own-risk rule, in general those who actually enter into regulatory contracts are

deduction is implicit, but so was the contractual promise upheld in Winstar. We believe that the more explicit the promise, the stronger all the arguments addressed in this section for enforcing the contract become. Thus, throughout this discussion we are assuming that our unmistakability approach, as opposed to the Supreme Court's approach in Winstar, is in force.

${ }^{157}$ However, as the recognition of relational contracts suggests, the expectations created by past performance are sometimes rightly treated as the equivalent of an explicit promise.

${ }^{158}$ See Federal Crop Ins. Corp. v. Merrill, 332 U.S. 380, 381-86 (1947) (holding that the government is not bound by interpretations of law provided to private parties by administrative officials). For a more recent application of this principle, see Office of Personnel Management v. Richmond, 496 U.S. 414 (1990) (reiterating the holding of Merrill while also admitting the possibility of estoppel against the government in extreme cases). For a discussion of this line of cases, see Koniak, supra note 110, at 600 $\mathrm{n} .93$ (reviewing the cases which demonstrate that the government is bound by the advice of its agents only in rare circumstances).

159 See Merrill, 332 U.S. at 381-86 (holding that the government's law-making power will not be held hostage to the word of a government agent, however honestly given or relied upon). It is interesting to note that the plurality in Winstar cited the dissent in Merrill as if the majority opinion in that case had not been consistently followed. 
likely to be sophisticated players with ample access to legal counsel. In short, if we do not reorder government authority in the interest of being fair to those most likely to be ignorant of the formal legal rules, we surely need not do so for those sophisticated enough to demand the government's word in a writing ostensibly supported by mutual consideration. ${ }^{160}$

While those with regulatory contracts are likely to be sophisticated, at least in relation to those who might rely on the word of a government agent as to the meaning of law, they are arguably more vulnerable in one sense. When the government breaks its promise to a particular industry, entity, or individual, after having induced performance that confers some benefit on the government (the consideration that underlies the contract), the fairness equation is arguably quite different than when a court, an agency, or the legislature renounces a legal interpretation offered by a government agent gratis, or, for that matter, when the government changes a broad-sweeping law (such as the Social Security law) that affects the public at large. The prospect of opportunism is much greater in the regulatory contract context than it is either when no particular benefit is conferred on the government in exchange for its word (the advice situation) or when a law of general application is changed or interpreted in some new fashion (most legislative and many advice situations). ${ }^{161}$ The in-

${ }^{160}$ For a discussion of the wisdom of the first doctrine, see Koniak, supra note 110, at 599-601 (discussing the implications of binding the government to the legal interpretations provided by its agents, as well as the implications of binding the corporations who have sought the advice of those agents).

${ }^{161}$ Indeed, under the pre-Winstar doctrine, the government's contractual obligations might be excused if they contravened subsequent regulation of a "public and general" nature. As Justice Souter acknowledged in his Winstar plurality, this "public and general" doctrine "reflects the traditional 'rule of law' assumption that generality in the terms by which the use of power is authorized will tend to guard against its misuse to burden or benefit the few unjustifiably." United States v. Winstar Corp., 518 U.S. 839, 897 (1996) (plurality opinion). Justice Souter found that FIRREA was not "public and general" regulation, however, because its impact upon "public contracts" - that is, the alleged forbearance agreements between regulators and thriftswas not "merely incidental to the accomplishment of a broader governmental objective," but rather was tainted with the government's self-interest in avoiding its compensation commitments. Id. at 897. Justice Souter thus added an intent or motivational element to the public and general doctrine. We question the utility of any doctrine that turns on the generality of a new regulation (a difficult-to-assess criterion) and the extent of governmental "self-interest" in the passage of new regulation (an impossible-to-assess criterion). At any rate, it seems to us that FIRREA did operate to advance the broad governmental objective of salvaging a banking regulatory system, the laxness of which had resulted in a major banking crisis that threatened the general economy and the welfare of many Americans. 
creased likelihood of government opportunism seems to explain why the Court, in both the regulatory takings context and the regulatory contracts context (at least before Winstar), was most likely to require compensation when the new regulation adversely affected the few rather than the many. ${ }^{162}$

We are not, however, persuaded that this argument justifies judicial enforcement of regulatory contracts. First, although the party holding a particular regulatory contract may be only a single person or a few individuals or corporations, that does not mean that such an entity cannot make its voice effectively heard in the political process. The entities that enter into regulatory contracts invariably control important economic resources, and wealth magnifies voice in our political system. Second, a private party who enters into a narrow regulatory contract (such as a contract which only affects that party) should know ex ante that such contracts are more susceptible to opportunistic breach than contracts that cover a large industry. Presumably, that private party will adjust its expectations of the value of the contract based on these political understandings. Hence, there is no "unfair surprise" but only the assumption of political risk.

\section{B. Does Economic Analysis Justify Judicial Enforcement of Regulatory Contracts?}

In approaching the question whether a particular legal rule will or will not enhance the net social welfare and thus be efficient or inefficient, economists conventionally assume that the relevant members of the polity maintain stable preferences over time. This premise runs counter to our assumptions about preferences, as reflected in our earlier discussion of majoritarianism: we assume that preferences may

${ }^{162}$ On some accounts, the Takings Clause should protect citizens against unfair singling out or discrimination much as the Equal Protection Clause does in the context of classifications accorded heightened scrutiny. See Joseph L. Sax, Property Rights and the Economy of Nature: Understanding Lucas v. South Carolina Coastal Council, 45 STAN. L. REv. 1433, 1454 n.102 (1993) (arguing that Justice Stevens's dissent in Lucas advances an equal protection perspective of the Takings Clause and maintaining that "[t]here is an equal protection element in the Takings Clause"); $A$ Colloquium on Lucas: Panel Discussion, 23 ENVIL. L. 925, 929 (1993) (comment of Michael Blumm, Professor) $("[T]$ he takings clause ought to be thought of as a kind of equal protection law for property holders."). A court adopting this equal protection-type view of the Takings Clause might find a taking where a government breached a regulatory contract with one private entity while honoring identical or substantively similar contracts with other entities. We would not necessarily disagree with such an approach because, as we have said, we believe that constitutional norms such as equality, as advanced in our evolving constitutional law, legitimately can take precedence over majoritarian concerns. 
change and, indeed, that public challenges to preferences regarding public policy and the evolution of those preferences are essential to any meaningful conception of democracy.

Even if we employed the standard economic assumption of stable preferences over time, we would still believe that judicial enforcement of regulatory contracts is unlikely to enhance net social welfare and thus operate efficiently in the sense we are using that term. ${ }^{163}$ As a preliminary matter, we recognize that a rule against judicial enforcement of regulatory contracts does carry some social costs, which in certain cases are quite large. ${ }^{164}$ Some regulatory contracts-in particular, the "pure" opportunism protection contracts discussed above ${ }^{165}$ represent the most cost-effective way for society to achieve a particular end that requires the cooperation of private parties. In the absence of judicial enforcement and the additional protection it provides against government opportunism, some private parties may be unwilling to bear the risk of loss from government opportunism and thus may decline to enter and fulfill socially beneficial regulatory contracts. ${ }^{16}$

On the other hand, there is good reason to doubt that regulatory contracts will represent efficient solutions to perceived social prob-

${ }^{163}$ For that reason we do not need to address the question whether and, if so, when efficiency considerations might trump the majoritarianism concerns outlined above. One of us, Susan Koniak, believes that no argument based on the purported "efficiency" of a particular practice could justify political or legal practices as fundamentally inconsistent with majoritarianism, as she perceives the enforcement of regulatory contracts. Moreover, she believes that no argument purporting to demonstrate the "efficiency" of judicial enforcement of all regulatory contracts can be sustained.

${ }^{164}$ Indeed, one of us, David Dana, has analyzed at some length the possible costs that result from the absence of a firm guarantee of compensation for costs resulting from changes in natural preservation regulation. See David A. Dana, Natural Preservation and the Race To Develop, 143 U. PA. L. REV. 655, 668-95 (1995) (discussing "the social costs of uncompensated natural preservation regulation"). Dana continues to adhere to that analysis, which suggests that some legal response to "the race to develop" might be in order. Dana does not believe, however, that full insurance for regulatory change by means of regulatory contracts is the appropriate legal response because: (I) serious normative concerns weigh against the recognition of firm rights to full insurance or compensation (whether those rights are based in contract law or the constitutional law of takings); (2) a special exception for natural preservation regulation would be difficult, although perhaps not impossible, to justify and maintain; and (3) alternative means to a full compensation guarantee exist, such as ex ante or ex post partial payments, by which government decision makers can curb "the race to develop." See generally id.

${ }_{165}$ See supra Part II.C (discussing opportunism protection in regulatory contracts).

${ }^{166}$ As we have said, however, we believe that the reputational constraints on the government as a repeat-player mean that it will generally abide by specific contractual commitments even in the absence of any threat of judicial enforcement. 
lems-that is, solutions that yield greater social benefits than costs. ${ }^{167}$ First, as discussed above, some regulatory contracts will simply reflect capture. It is logical to assume that capture contracts are highly unlikely to yield greater social benefits than costs. ${ }^{168}$ While the procedural protections we advocated are designed to reduce the possibility that capture contracts will be made (and subsequently enforced), transparency is no guarantee against the formation of capture contracts. In short, there is no foolproof method for a court ex post to distinguish reliably which regulatory contracts are the product of capture as opposed to a reflection of honest compromise or a pure effort

${ }^{167}$ One school of public choice scholarship depicts politicians as a-or perhaps the-key interest group. According to this view, politicians extract favors or "rents" from constituents by threatening to impose costly new regulations on them. See generally FRED S. MCCHESNEY, MONEY FOR NOTHING: POLITICIANS, RENT EXTRACTION, AND POIMICAL EXTORMON (1997) (developing this thesis at length). Writing in this tradition and addressing the specific context of tax reform, Professors Ramseyer and Nakazato have argued that politicians will disfavor firm guarantees of compensation for regulatory change because such guarantees limit their ability to threaten constituents with costly, uncompensated regulatory change. Thus, Ramseyer's and Nakazato's analysis suggests that regulatory contracts will constrain rent extraction by politicians, and, for that reason, regulatory contracts are socially efficient. See Ramseyer \& Nakazato, supra note 76, at 1175 (arguing that the ability of legislators to extract payments from their constituents is dependent upon their ability to threaten changes in the law).

Even if one accepts the view of politicians as rent-extractors, the analysis offered by Ramseyer and Nakazato is unpersuasive. For one thing, incumbent politicians may rationally reject a strategy of successive "shake downs" of constituent groups because those shake downs may eventually backfire. Rather than continuing to pay rents each legislative cycle in order to avoid costly new regulations, constituent groups may throw their support to political challengers. Moreover, even assuming incumbent politicians do not face a re-election risk, there is no reason to believe that regulatory contracts (and the protection against uncompensated regulatory change they provide) will result in less net rent-extraction by politicians. Consider the case where the loss of a particular tax benefit would cost the industry $\$ 1$ million in present value. Under these facts, the industry would be willing to pay either (1) some amount approaching $\$ 1$ million in present value each year for 10 years to prevent the passage of a reform bill stripping the industry of the tax benefit, or (2) some amount approaching $\$ 10$ million for a regulatory change for a term of 10 years. The total rents paid in either case would be the same.

${ }^{163}$ See Daniel R. Fischel \& Alan O. Sykes, Government Liability for Breach of Contract 47-53, 61 (Sept. 15, 1998) (unpublished manuscript, on file with authors) (arguing, largely based on concerns about capture, that pre-Winstar doctrine, with its robust procedural and substantive protections for sovereignty, was more efficient than the Court's apparent re-reading of that doctrine in Winstar). We add an additional argument to those offered by Fischel and Sykes about the inefficiency of capture contracts. To the extent that capture contracts are perceived as such-in other words, understood at some point during their duration as the product of an industry's effective control of a government agency -and to the extent that costs are calculated to include increasing cynicism about the nature of our democracy among those who view the contract that way, capture contracts are never likely to yield greater gains than losses. 
to prevent opportunism by the government. That means any enforcement of regulatory contracts will necessarily entail the enforcement of some inefficient deals.

On the other hand, as we have argued, strong procedural protections minimize the chance that capture contracts will be enforced. Capture aside, there are still strong reasons to doubt the efficiency of regulatory contracts. In other words, it is our claim that even those regulatory contracts negotiated by independent, fair-minded government agents, operating at arms-length from their contracting partners, are likely to be inefficient. First, government agents are likely to have insufficient information on which to base regulatory contract decisions, which could lead to inefficient contracting. Second, regulatory contracts are likely to encourage private parties to engage in inefficient investment by purchasing what amounts to full insurance against the risk that the law will change. We address each of these problems in turn.

There are two reasons to believe that government agents will have inadequate information. First, private actors are more likely than government actors to have accurate information by which to estimate the risks (both long- and short-term) that the private actors' conduct poses to the public, to the extent that such information is presently available. Indeed, private actors might seek out and consummate regulatory contracts precisely in those situations where they enjoy such an informational advantage. In the language of economics, this problem is known as adverse selection. ${ }^{169}$

Many aspects of the tobacco story illustrate the informational disadvantage that may plague the regulatory contract process. The deal the tobacco companies put on the table provided for the release of warehouses of information on what those companies knew, when they knew it, and what they did. ${ }^{170}$ Obviously then, when the contract was being negotiated, the industry had information not available to government agents that helped it predict the likelihood of public support for stricter industry regulation. The industry-proposed deal also detailed marketing restrictions designed to reduce public, and particu-

169 For a discussion of how adverse selection can undermine an efficient insurance market, see KENNETH S. ABRAHAM, INSURANCE LAW AND REGULATION: CASES AND MATERIALS 34 (2d ed. 1995).

${ }^{170}$ See Proposed Tobacco Settlement, June, 20, 1997, supra note 83, app. VIII ("Public Disclosure of Past and Future Tobacco Industry Documents and Health Research"). 
larly teenage, smoking. ${ }^{171}$ Undoubtedly, the information available to the industry on the relationship between various forms of advertising and the consumption of cigarettes by teens and others was vastly superior to that possessed by the government. Additionally, the deal included penalty provisions to be paid by the industry in the event that teen smoking was not reduced by specified percentages. ${ }^{172}$ Again the tobacco companies possessed vastly superior information than the government concerning the likely financial effect of the deal on their financial operations. ${ }^{173}$ Indeed, the government's information on what the deal would actually cost the companies and on whether the "penalty" provisions would provide the hoped-for incentives was wellnigh nonexistent. ${ }^{174}$

When the government compensates private parties for losses incurred by changes in law either under the Takings Clause's mandate to do so, by phasing-in a legal change, or by including a grandfather provision in a law of general application, adverse selection is unlikely to be a problem of major proportions. ${ }^{175}$ That is not to say that it is generally efficient or good policy to provide such compensation. Both Professors Graetz and Kaplow have made strong arguments against the efficiency of transition relief even when adverse selection is not likely to be a factor. ${ }^{176}$ Our point here is that even if there are some

${ }^{171}$ See id., tit. I.A ("Restrictions on Marketing and Advertising").

172 See id., tit. II (stating that "Look Back" Provisions/State Enforcement Incentives provide that if specified reductions in underage smoking do not occur by target dates, the FDA will "impose a mandatory surcharge" on the industry "based upon an approximation of the present value of the profit the industry would earn over the lives of all underage users in excess of the target," not exceeding an annual cap for the cigarette companies of $\$ 2$ billion, which could be partially abated-up to $75 \%$-if the companies could show they fully complied with the Act).

${ }^{173}$ See Jon D. Hanson \& Kyle D. Logue, The Costs of Cigarettes: The Economic Case for Ex Post Incentive-Based Regulation, 107 YALE L.J. 1163, 1181-86 (1998) (emphasizing the informational advantages of the tobacco industry and the consequent likely ineffectiveness of the command-and-control regulatory restrictions embodied in the June 20, 1997 tobacco proposal); Shankar Vedantam, Tobacco Pact's Effect on Profits Is Trade Secret, BOSTON GLOBE, Dec. 13, 1998, at A20 ("No one outside of the [tobacco] industry can predict precisely what will happen' [as a result of the settlement] .... Only the companies 'know what will happen, how much cigarette sales will decline, how it will affect revenues and share price." ) (quoting Kenneth Warner, a specialist on health policy at the University of Michigan).

${ }^{174}$ See Vedantam, supra note 173, at A20 ("The precise balance of price and smoking rates, with its implications for future markets and current stock prices, is a closely guarded industry secret.").

${ }^{175}$ See Kaplow, supra note 3 , at 544 (noting that adverse selection is unlikely to occur when a law treats individuals in the same manner).

${ }^{176}$ See Graetz, supra note 3, at 64-73 (arguing that transition relief prevents the im- 
situations, as Kaplow surely concedes, in which it might be efficient to compensate private parties for changes in legal rules, regulatory contracts are highly unlikely to reflect those situations because adverse selection is particularly likely to be a problem.

The government's second informational problem is at least as serious. Even if the government and the private party have identical information at the time of contract formation regarding the present costs to the public of the private party's conduct, the government's ability to assess the long-term costs and benefits of alternative future policies will rarely, if ever, equal that of the private party. Even if we assume that societal preferences remain stable, as we have already done, however counterfactual and normatively problematic that assumption is, the difficulty of calculating future societal benefits and costs is still enormous. Not only are the utility curves of corporations (and even individuals) simple compared to that of societies (and at least in the case of corporations less likely to include preferences satisfied by "units" difficult to measure), but the number of variables that might seriously affect the future net social utility of adhering to a certain policy is also staggering. Because government agents contract in an extremely complex environment, the likelihood that they will reliably estimate the effects of all possible variables on the utility of future adherence to a particular regulatory regime is extremely low. ${ }^{177}$ Government agents, therefore, are very likely to make bad deals regardless of how earnestly they try and whether or not at the time of contract formation they and their private contracting partner share all

plementation of efficient government policies); Kaplow, supra note 3, at 615-16 (noting that, as a matter of efficiency, compensation is an unwise policy).

177 For a discussion on decision making in complex environments-environments in which the assumption that agents are aware of how imperfect their information is and are capable of quantifying their own ignorance does not hold-see JOHN GEANAKOPLOS \& LARRY GRAY, WHEN SEEING FURTHER Is NOT SEEING BETIER (Cowles Found. for Research in Econ. at Yale Univ. Paper No. 797, 1992). The authors conclude that in environments in which it is impossible to calculate with any degree of certainty the consequences of all possible actions, looking to the future is not likely to be the best method of making decisions. In situations in which the normal assumption of economic theory-that agents are aware of their own information deficits and are capable of quantifying their ignorance-does not hold, knowing more and searching deeper in the decision tree is not the best method of making decisions. Geanakoplos and Gray articulate five principles deduced from mathematical formulas (which we do not profess to follow) for optimal decision making in such environments. In sum, they conclude that only when all the error probabilities are very small does it make sense to base decisions on the values one assigns to the terminal nodes in a complex decision tree. Our point is that this condition is not likely to be met in the context of assessing the costs and benefits of future adherence to a particular government policy. 
known facts. ${ }^{178}$

In addition to the information problems, regulatory contracts are likely to create inefficient behavioral incentives because they remove the incentive for the private contracting parties to hedge against the possibility that the regulatory policies "frozen" into place by the regulatory contract are (or will turn out to be) socially detrimental and that ultimately, the government will realize as much and change them. ${ }^{179}$ Consider, for example, a regulatory contract that promised an industry immunity from tort suits for a certain kind of injury, like that caused by second-hand smoke, for the next twenty-five years in exchange for a lump-sum payment to the government or some other form of consideration. Assume, however unlikely, that at the time of contract formation the tobacco industry and the government have identical information on the hazards of second-hand smoke. Over the term of the contract, however, the industry becomes increasingly aware that the range and severity of illnesses caused by second-hand smoke are much greater than previously thought and that the ventilation systems previously believed to be effective are ineffective.

In the absence of a governmental promise to pay full compensatory damages resulting from the enactment of a law or regulation ending the companies' tort immunity, the tobacco industry would have a greater incentive to act promptly to reduce the societal costs associated with its product. The industry might, for example, invest in developing cigarettes that disperse less smoke and thus cause less second-hand illness. ${ }^{180}$ Notice that a law that eliminated tort liability would not have the same effect on incentives as a regulatory contract because if the law were repealed, the industry would be required to pay tort damages without compensation from the government. ${ }^{181}$

${ }^{178}$ The complexity of determining social efficiency affects all government decision making, but in the noncontractual and ordinary legislation and regulation settings, government decision makers can correct mistakes once they realize them, without paying fines.

${ }_{179}$ Here our argument largely tracks that of Professor Kaplow, supra note 3, at 52732 (arguing that the efficient level of investment is generally that where the investor bears all real costs and benefits of his decision).

${ }^{180}$ See Hanson \& Logue, supra note 173, at 1268 (arguing that incentive-based regulation is superior to command-and-control regulation in that it forces the industry to take precautions).

181 One could make precisely the same argument using the Winstar example of aggressive lending by thrifts. Let us assume, for the sake of argument, that the government thrift regulators were not "captured," but rather truly believed that the forbearance policies represented sound public policy. Let us also assume that the bank mergers the regulators wished to facilitate were, at least from the vantage of that mo- 
If, instead of full compensation, regulatory contracts were enforced by payments of partial compensatory damages, they might produce, at least in theory, a socially optimal solution, as we suggested in our discussion of liquidated damages. A guarantee of partial damages might be enough to induce the desired private-party behavior: the bank mergers thought socially desirable by the regulators in Winstar, the lump-sum payments to fund government projects some government actors thought desirable in negotiating the tobacco deal, or the limits on advertising to teens some thought would produce significant social benefits. At the same time, failing to fully compensate the private contracting party upon government breach would reduce that party's incentives to ignore the risks that its behavior might cause harm not taken into account by the government at the time of contract formation. ${ }^{182}$ Partial damages are, however, not a standard remedy in contract law. Courts will award them only if ex ante the parties specified a partial damages formula or numerical limit in the contract. In order to specify a damages formula or limit, however, the government would need to know fairly accurately the risks that might result from the private contracting party's post-contractual conduct. Government ignorance or at least highly imperfect information in this regard seems to us, to put it mildly, a much more plausible assumption.

\section{Would Refusing to Enforce Regulatory Contracts Destabilize "Ordinary" or "Routine" Government Contracting?}

In explaining its decision to ignore the entrenching effects of a judicially enforceable damages remedy for regulatory contracts, the plurality in Winstar expressed concern that there is no way to distin-

ment, reasonable efforts to shore up a troubled financial system and thus in the public interest. It was not the case that the regulators were simply hoodwinked. But let us also assume that, at the time they entered the regulatory contracts, the banks who agreed to the mergers had better information than the regulators about the default risks that would be involved in maintaining aggressive post-merger lending policies, and, in addition, over time the banks became increasingly aware of these risks while the regulators remained essentially in the dark.

In this scenario, in the absence of a guarantee of full compensatory damages, the banks might have engaged in somewhat conservative post-merger lending and reservesbuilding with the hope that this cautious behavior would reduce or eliminate the risk of regulators imposing new reserves requirements. That caution might have translated into fewer bad loans and, hence, fewer defaults, with all the negative externalities they entail. Whatever societal benefits were achieved by the bank mergers through the regulatory contracts may well have been outweighed by the social costs of the aggressive lending that the regulatory contracts induced. sions).

See supra text accompanying notes 106-07 (discussing liquidated damages provi- 
guish contracts that infringe sovereignty, which we have been calling regulatory contracts, from the unproblematic, everyday procurement and other ordinary-seeming business contracts that all governments make. According to Justice Souter, there is no principled way to distinguish between such ordinary "business" contracts and regulatory contracts because any line one might draw would lead to "enormous analytical difficulties" and would defy "any limiting principle."

Souter's concerns notwithstanding, it seems relatively straightforward to distinguish regulatory contracts from other types of contracts. Regulatory contracts contain a promise not to change a specified government policy; nonregulatory contracts contain no such promise. It is that simple. The Winstar plurality hints at the claim that there may be many cases where it is difficult to decide whether a particular agency action or a legislation embodies a regulatory contract. The plurality, however, identifies no examples of such hard cases, and we are not aware of any. ${ }^{184}$

This is not to say that Souter was imagining analytical difficulties that do not exist. As we have said, the Court's pre-Winstar efforts to protect sovereignty by picking and choosing which government powers could be the subject of enforceable contracts and which could not was incoherent. They were incoherent because no rhyme or reason

${ }^{183}$ Justice Souter makes this point in the context of explaining his abandonment of the unmistakability doctrine and other procedural requirements for the enforceability of regulatory contracts. See United States v. Winstar, 518 U.S. 839, 886 (1996) (plurality opinion) (noting the difficulty of distinguishing "those contracts that are 'regulatory' in nature" from those that are not). As we have explained, these procedural requirements function to promote political transparency, which we believe would be a good thing in "ordinary" government contracts as well as in the less-than-ordinary regulatory contracts at issue in Winstar. Indeed, by statute, most ordinary public contracts, such as procurement contracts, already must satisfy a wide range of transparency-enhancing procedural requirements.

${ }^{184}$ One potentially problematic type of "deal" (typified by the deal at issue in United States Trust Co. v. New Jersey, 431 U.S. 1 (1977)) is that in which a government borrows money and, as a condition of receiving the money, promises to maintain certain government policies or else to forfeit the right to continue the loan. Such deals, although falling within the debt contract category for which we would generally advocate judicial enforcement, also contain characteristics of what we have termed regulatory contracts and implicate some of the concerns we have raised regarding such contracts (such as taxing future majorities' policy choices and transferring control over public policy to private parties). Therefore, we would include such deals within the universe of contracts that we believe courts should not enforce. In any event, notwithstanding the centrality of the United States Trust case to contemporary regulatory contracts jurisprudence, we have found no instance of the federal government borrowing money in exchange for a promise to keep a particular policy in force, and, to our knowledge, state and local governments do not normally borrow money by making such policy promises either. 
seemed to distinguish those powers on the no-contract list from those on the free-to-contract list; even predicting which power the Court would decide was implicated by a particular contract was no easy task. ${ }^{185}$ Thus, the plurality in Winstar had reason to bemoan the analytical difficulties, or rather the analytical emptiness, of previous efforts in this area.

While we thus have some sympathy for the Winstar plurality's critique of past doctrine, its proposed alternative-the enforcement of all regulatory contracts except those in which awarding damages would be tantamount to specific performance-is hardly an improvement. First, other than contracts in which the government promises to maintain a specified tax deduction, rate, or interpretation, the plurality tells us nothing about what else, if anything, its line intends to proscribe. ${ }^{186}$ More important, the analytical justification for the line is weak as it depends on the plurality's assertion that the only infringements on sovereignty worthy of concern are those that directly forbid the government from taking a particular action. The plurality's line leads to the ludicrous result that contracts promising a specified tax treatment for those investing in the inner city would be unenforceable, but contracts promising to compensate six multinational corporations for all lost business caused by the government's breach of its promise not to engage in military operations in twenty specified countries would be enforceable as not unduly infringing upon our nation's sovereign prerogatives.

The analytical challenge for us is whether our line reasonably tracks the problems we have identified with the enforcement of regulatory contracts. Are the entrenchment and transfer-of-power problems that condemn regulatory contracts equally present in government contracts that fall outside our line, specifically those that do not

${ }^{185}$ One might argue that this unpredictability in the pre-Winstar regulatory takings law had some significant benefits. An uncertain entitlement to full compensation for regulatory change may, for the private party to a contract, be the economic equivalent to a firm entitlement to partial compensation for regulatory change, which, in substance, is the same thing as partial insurance. Thus, under a regime of uncertain entitlements to full compensation for contract breaches, private parties might act as they would under a partial insurance regime, which, as we have explained, may be optimal under conventional economic analysis. The problem with this argument, however, is that to be optimal, partial insurance must be partial in a manner that reflects the ability of the private party to minimize the risk-being "partial" in and of itself is not sufficient.

${ }^{86}$ See Winstar, 518 U.S. at 880 (commenting that agreements for tax exemptions impermissibly limit the scope of "sovereign authority"). 
promise a specified legal regime ${ }^{187}$ In that case, the logic of our position would force us to reject the enforcement of all government contracts, which is precisely the result Souter sought to avoid. ${ }^{188}$

First, all regulatory contracts strongly implicate entrenchment concerns because, by their very design, they tax particular policy choices facing future government decision makers. That is not true of the other contracts governments enter. Commitments to spend money to procure some good or service, pay a debt, or insure against a risk outside the control of government policymakers (like government contracts with individuals to provide flood insurance) do not tax particular policy choices to be made by future legislators in the same way as regulatory contracts. For example, if in 2000 the government commits to pay bondholders $\$ 1$ million in 2030 , that commitment does not make any particular policy choice more or less expensive in 2030 , although it certainly may affect the range of policy options open to legislators. ${ }^{189}$

Second, at least as to regulatory contracts that lack liquidated damages clauses (to our knowledge, historically all of them), regulatory contracts empower private contracting parties to drive up the cost of future regulatory changes. This results not only in a fortification of the entrenching effect of these contracts but also in a transfer of control over policy choices from the government to private hands. Again,

${ }^{187}$ Our functional concerns about regulatory contracts-that they entail a kind of anti-majoritarian legislative entrenchment and that they may unduly empower private actors-are strongest in the case of long-term, indefinite, or multi-year regulatory contracts and least strong in the case of regulatory contracts designed to last, for example, only a few months. It might be plausible to argue that the government decision makers are entitled to bind the government for the next few months, if not until the next legislative term, and that this contract duration is simply too short for the private contracting party to manipulate the magnitude of government liability for breach. Precisely because short-term regulatory contracts provide little protection against political change, however, we expect that parties will rarely, if ever, enter into them.

${ }^{188}$ See Winstar, 518 U.S. at 886 (stating the Court's unwillingness to subject all government contracts to unmistakability litigation).

${ }^{189}$ We do not mean to suggest that every imaginable procurement (or other nonregulatory) contract would constrain future government decision making to a lesser degree than every imaginable regulatory contract; that would be an implausible claim. We are proceeding on the basis of generalizations about certain legal categories of contracts because any legal rule short of "enforce everything" or "enforce nothing" requires the use of (one hopes helpful, but inherently imperfect) generalizations.

Moreover, we do not claim that our proposed legal regime would eliminate all entrenchment or otherwise objectionable government action or would be "ideal" in any meaningful sense. What we do claim-and what we think is a pragmatic criterion for any reform proposal-is that our proposed legal regime would be normatively superior to the one that currently exists. 
the other sorts of contractual commitments made by governments do not similarly empower private parties because, as a general matter, the outer limit of the government's potential monetary liability is set and publicly understood at the time of contract formation. ${ }^{190}$ In the procurement and debt context, for example, the government's liability normally cannot exceed the full purchase price of the goods or the face value of the debt instruments, no matter what strategic actions the contracting private parties take.

Finally, while our argument does not proceed on efficiency grounds, we believe that the enforcement of debt, procurement, and insurance-for-external events contracts is more likely to be efficient than the enforcement of what we have called regulatory contracts. Debt, procurement, and insurance-for-external events contracts are less likely than regulatory contracts to involve severe informational problems for the government. ${ }^{191}$ Procurement contracts generally are designed to span a relatively short period of time, requiring less complicated calculations as to what the future is likely to bring. Debt contracts do not require many, if any, calculations involving units of utility that are difficult to measure, and the variables likely to affect the costs and benefits of providing something like flood insurance are relatively simple compared to those involved in regulatory contracts. As to the moral hazard problem, partial insurance is not only standard but also relatively simple to calculate in government insurance contracts for matters other than changes in legal rules. Furthermore, government procurement contracts routinely include (as required by statute) termination-for-convenience provisions that function like partial insurance. ${ }^{192}$ Finally, because it is true that capture is a serious problem, at

190 The United States Constitution specifically authorizes the federal government to enter into both contracts for the sale of tangible government property and land and debt contracts. This constitutional imprimatur further distinguishes these sorts of contracts from regulatory contracts.

${ }^{191}$ We read the work of Kaplow and especially Fischel and Sykes as reaching the same conclusion as we do. See Kaplow, supra note 3, at 615 (arguing that governmental transition relief is generally undesirable, and reliance on the market to address the effects of changes in government policy is more efficient); Fischel \& Sykes, supra note 168 (arguing that pre-Winstar doctrine, with its robust procedural and substantive protections for sovereignty, was more efficient than the Court's apparent re-reading of that doctrine in Winstar).

${ }^{192}$ For example, imagine that the government enters into a procurement contract that provides for the purchase of military planes from a private company each year for the next 30 years. In the absence of a termination-for-convenience clause, the company would have little reason to take account of the risk that the perceived need for the military planes might diminish during the 30-year period. The termination-forconvenience clause might induce the company to take account of that risk by, for ex- 
least in the case of procurement contracts, we advocate procedural protections designed to reduce capture in the formation of all government contracts. ${ }^{193}$

Regulatory contracts are different from the other types of contracts governments enter. Judicial doctrine for many years tried, however imprecisely, to attend to those differences. The intuition that inspired that doctrinal struggle was correct. The pre-Winstar doctrine was messy and at times weak. Admittedly, it required clarification and stronger enforcement, but the trajectory of this doctrine should have been preserved. The Court signaled a change in direction in Winstar. It needs to turn back.

\section{CONCLUSION}

In the second century A.D., to become emperor of Rome, one needed to win the consent of the Praetorian guard both as a practical matter and, at least according to the Praetorians, as a matter of constitutional law. ${ }^{194}$ To guarantee the continued support of the Praetorians, emperors, after their selection, lavished money and other benefits upon the guard; later, the tradition of paying the Praetorians for their support became a legal requirement. ${ }^{195}$ In 193 A.D., convinced that they should receive the best price "for so valuable a commodity" as their consent, some of the guards decided on a new procedure. ${ }^{196}$ One of the Praetorians "ran out upon the ramparts; and, with a loud voice, proclaimed that the Roman world was to be disposed of to the best bidder by public auction." 197 They sold the throne. Although all in Rome understood that the guards were routinely and lavishly paid by emperors with public money and thus in some sense understood that public money was necessary to maintain this institution, Gibbon

ample, funding an ongoing research program exploring potential commercial uses for military production equipment and aircraft.

${ }_{193}$ At both the state and federal level, there are many statutory and regulatory requirements in place to limit corruption in government procurement. See generally W. NOEl Keyes, GOVERnMENT CONTRACTS UNDER THE FEDERAL ACQUISITION REGULATIONS (1996).

${ }^{194}$ See 1 EDWARD GIBBON, THE DECLINE AND FALL OF THE ROMAN EMPIRE 92 (1932) ("The advocates of the guards endeavoured to justify by arguments, the power which they asserted by arms; and to maintain that, according to the purest principles of the constitution, their [referring to the Praetorian guard] consent was essentially necessary in the appointment of an emperor.").

${ }^{195}$ See $i d$. (noting the tendency of an emperor to praise, flatter, and indulge the Praetorians in order to reinforce their support of his rule).

${ }^{196} I d$. at 93.

${ }^{197}$ Id. 
states that "[t]his infamous offer... diffused $a[]$ universal grief, shame and indignation throughout the city. ${ }^{198}$ What, however, did the auction change? In effect, sovereignty had been for sale long before this offer, albeit in a form that allowed the Romans to deny that reality.

The point of this paper is simple: We should not wait until the ongoing auctioning of our government-the auctioning not merely of laws subject to change by popular will, but rather of the underlying law-making authority itself-becomes so blatant and pervasive that it is no longer possible to sustain the conviction that the imperfections in our democracy have not consumed the ideal. We should act now. 
